\title{
Learning to lead: What constitutes effective training for student leaders in New Zealand secondary schools?
}

\author{
By \\ Bronwyn Davies
}

A four paper thesis submitted in partial fulfilment of the requirements for the degree of Master of Education Victoria University of Wellington 2011 


\begin{abstract}
Student leaders in New Zealand secondary schools may include tutors, head students, sports and cultural captains, mentors and prefects. This study is based on the premise that student leaders can provide inspiration to other students and work skilfully to shape the culture of a school. The possibilities that stem from the role of student leader can be endless, yet there seems to be little evidence of consensus regarding what kind of training should be provided for student leaders.

This is an investigation of student leadership training programmes. The main purpose is to discover what constitutes effective training for student leaders. This study is designed to provide educators with examples of what effective training could involve. It is a multiplecase study of three different New Zealand secondary schools. Data were collected through semi-structured interviews, an observation and a survey. The study uses a distributed leadership framework and thematic analysis of data.

This study reveals some aspects of effective student leadership training and, based on findings, includes recommendations for components of future training programmes. The analysis highlights the importance of creating a school environment that supports student leadership. The findings also reveal the value of designing leadership training programmes that adhere to principles of experiential learning.
\end{abstract}




\section{Acknowledgements}

There are a number of people and organisations who have made this thesis possible. Thank you so much for your support and help.

\section{Special thanks go to:}

The participants in my three schools, your enthusiasm and willingness to talk brought me a wealth of information. Your interest in leadership is sure to take you many interesting places.

The Ministry of Education and the PPTA for the study grant which enabled me to focus on this thesis in 2010. My school for allowing me to take up the grant and supporting my studies.

My supervisor, Ann Bondy, who has answered my endless questions and encouraged me to consider new approaches. Your professional advice and support has been much appreciated.

The staff in the post-graduate office at the Faculty of Education at Victoria University, for providing a space to study in and resources to use.

My friends and family for who have taken an interest, checked on my progress and given advice.

My supreme thanks go to my lovely husband, Lee. Your faith in me and this project is unwavering and greatly appreciated. 


\section{Table of Contents}

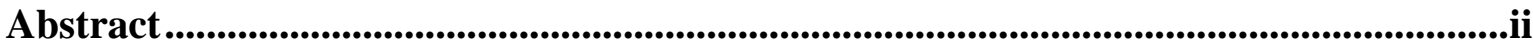

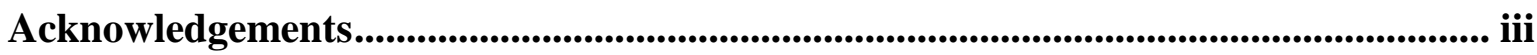

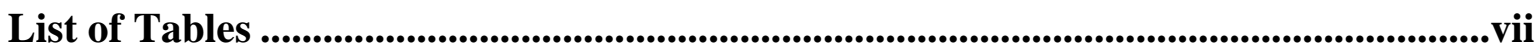

List of Figures .................................................................................................................... viii

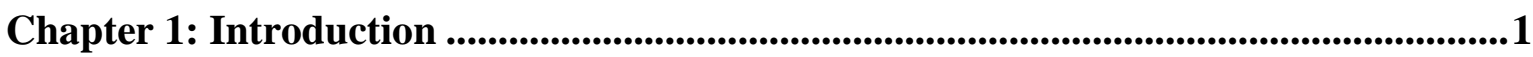

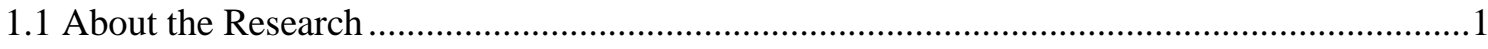

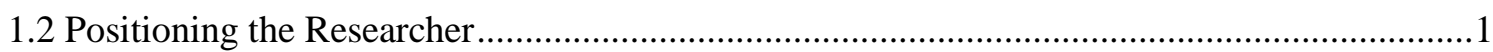

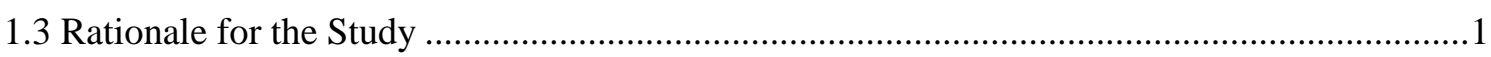

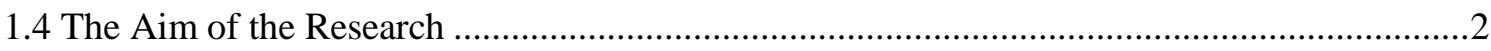

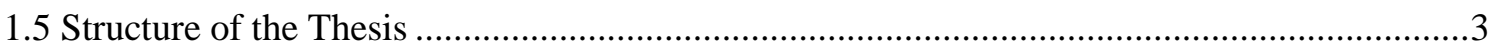

Chapter 2: Literature Review .........................................................................................................5

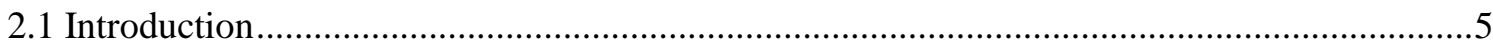

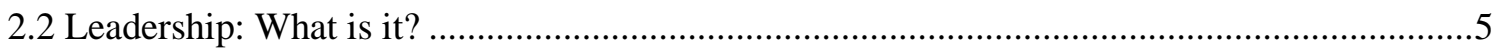

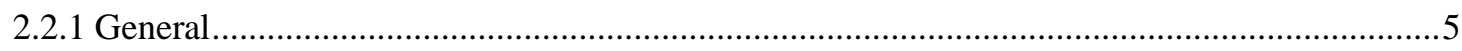

2.2.2 School Leadership.....................................................................................................

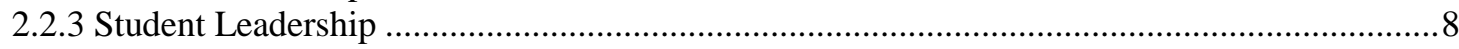

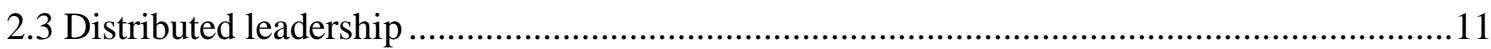

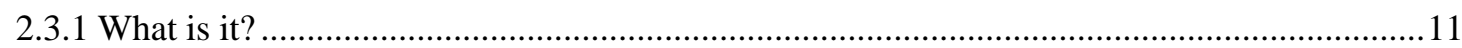

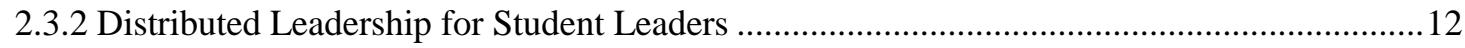

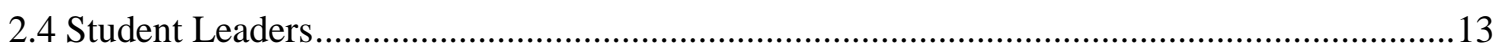

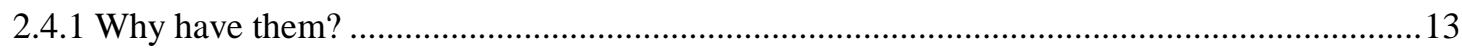

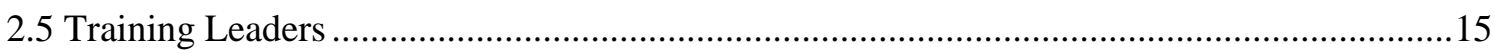

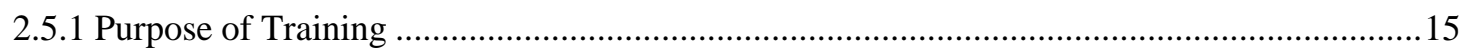

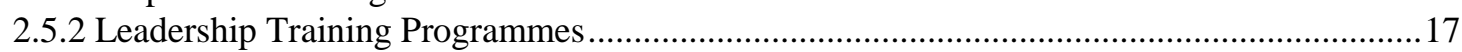

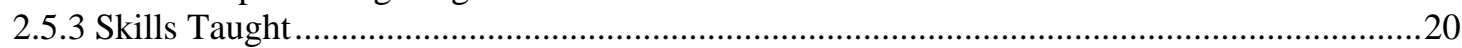

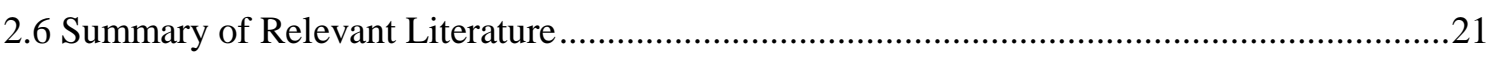

Chapter 3: Methodology ...............................................................................................................23

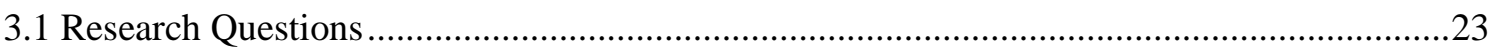

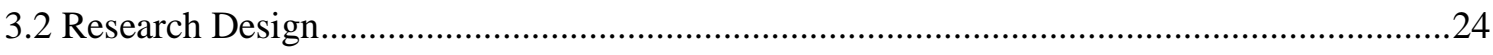

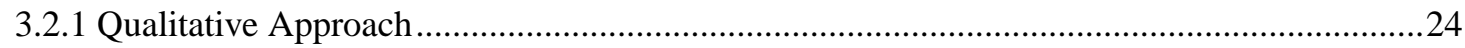

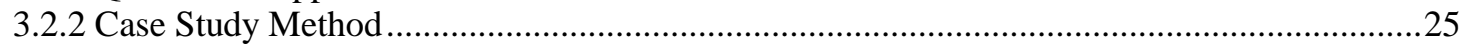

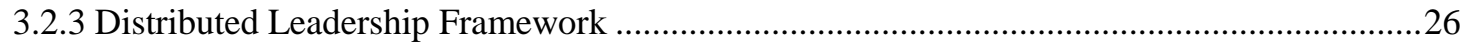

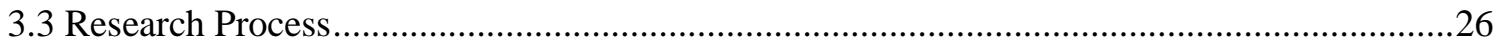

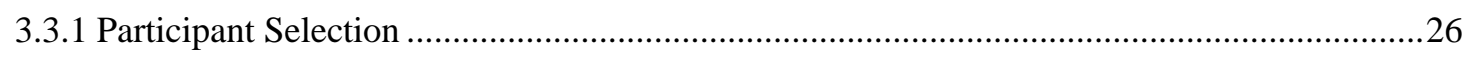

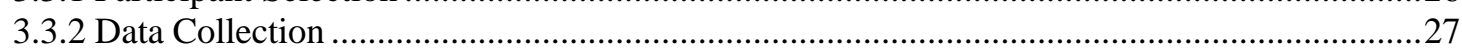

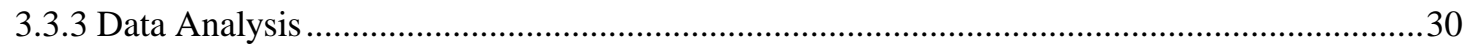

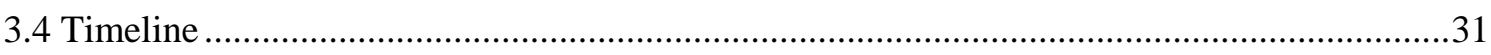

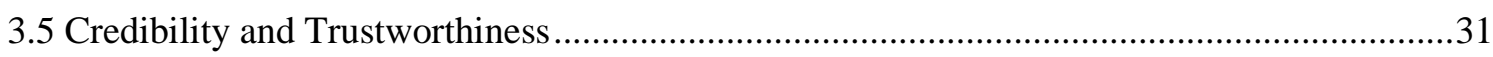

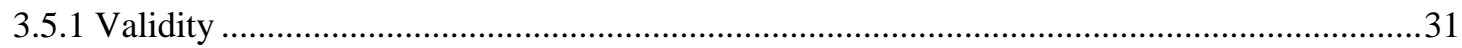

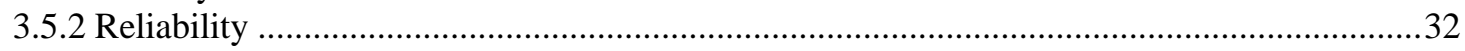

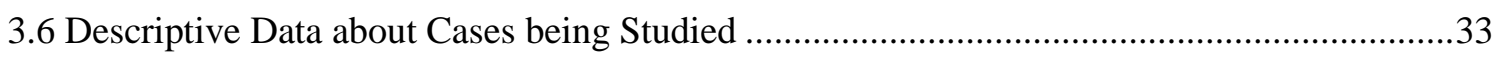

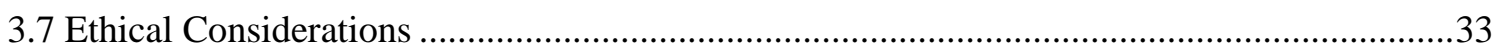

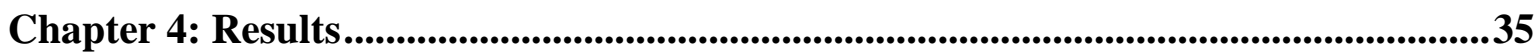

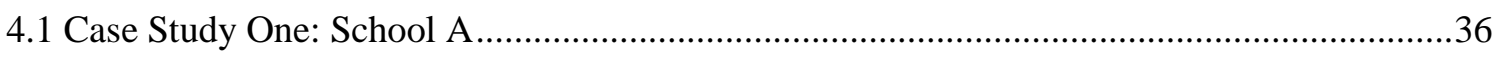




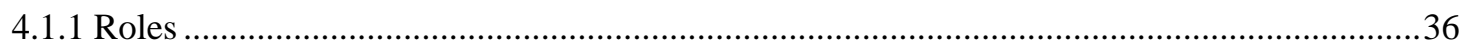

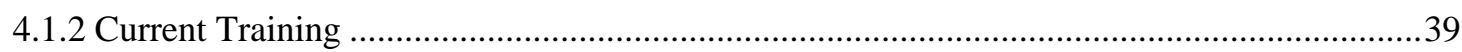

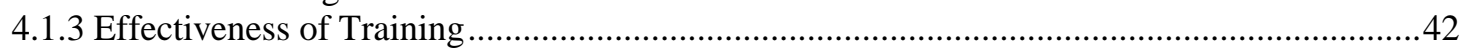

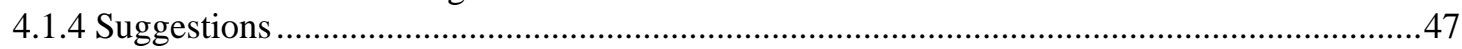

4.1.5 Community Connections .............................................................................................50

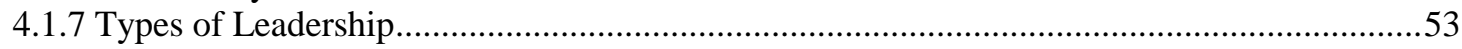

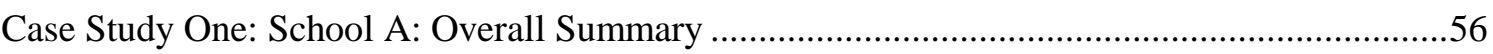

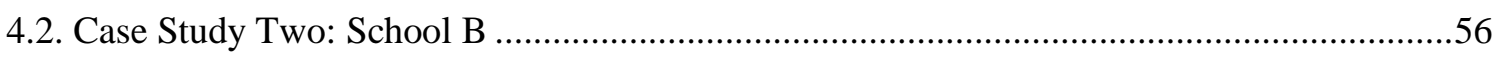

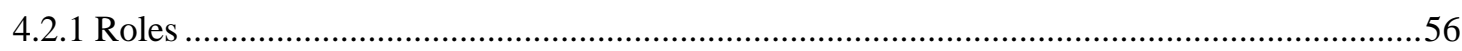

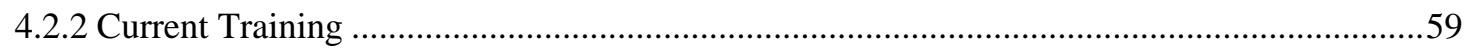

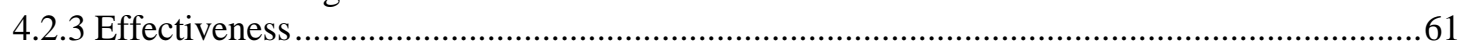

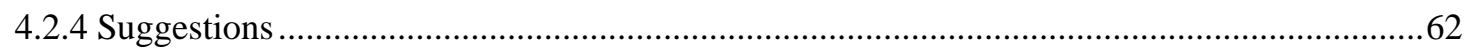

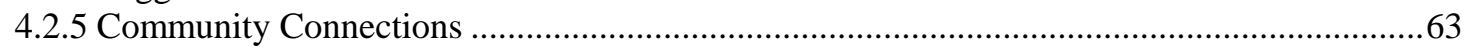

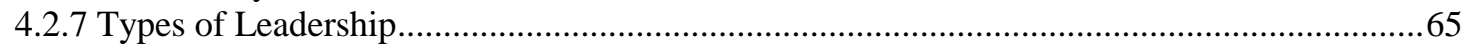

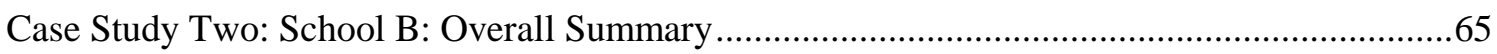

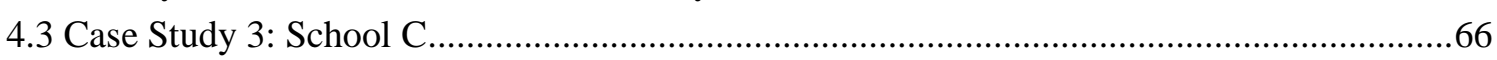

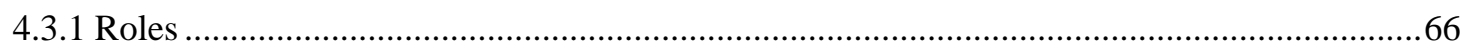

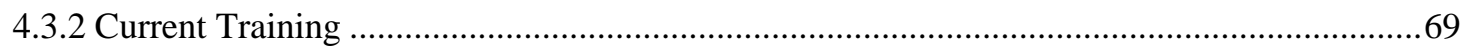

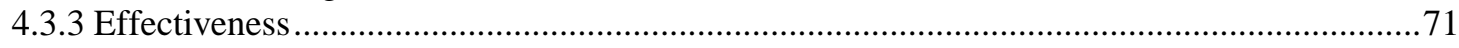

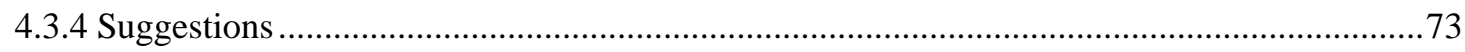

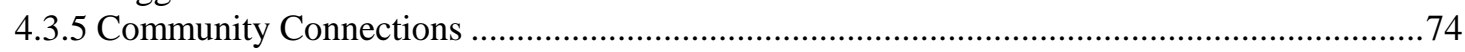

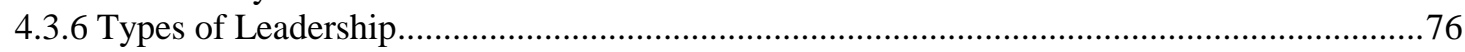

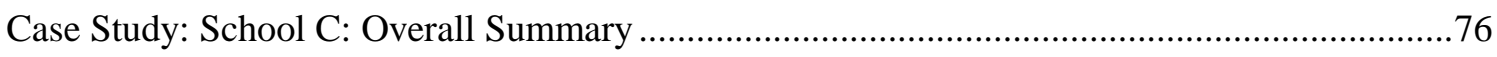

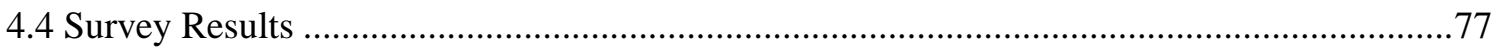

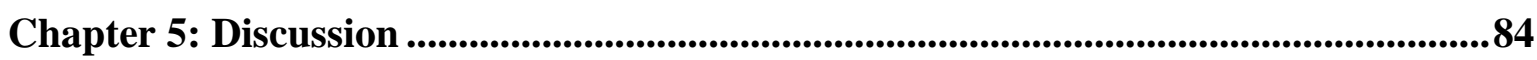

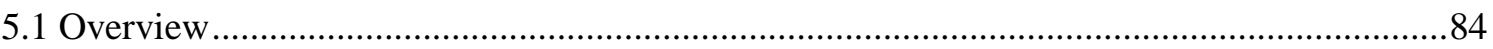

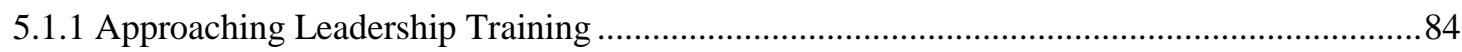

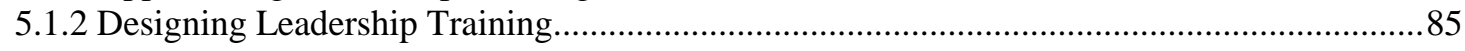

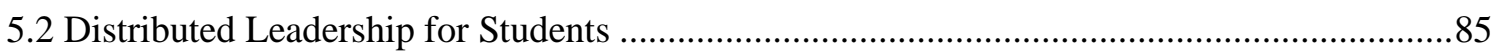

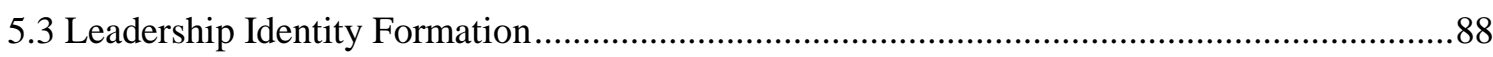

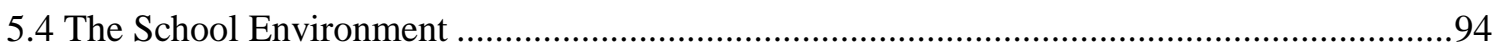

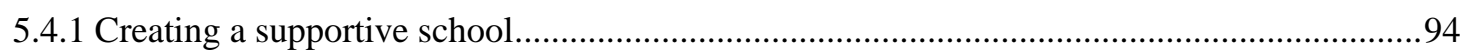

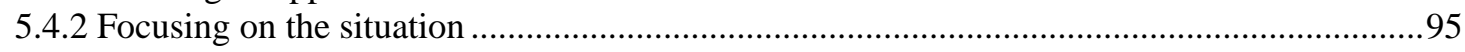

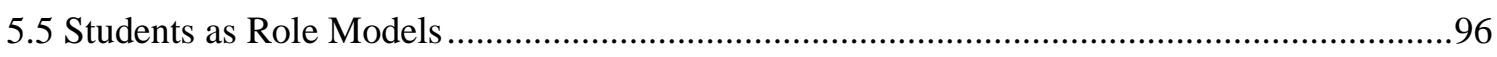

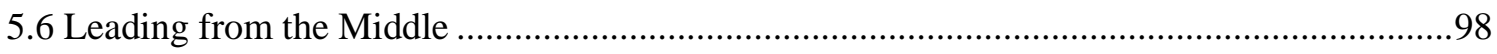

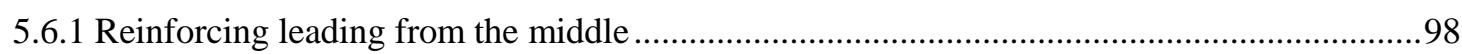

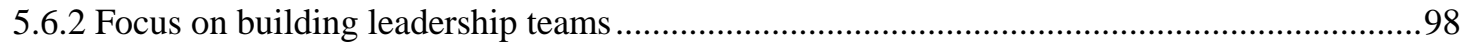

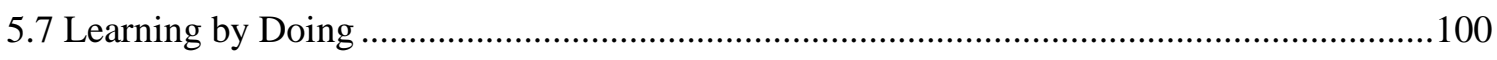

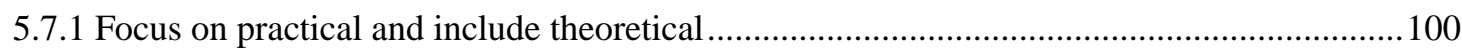

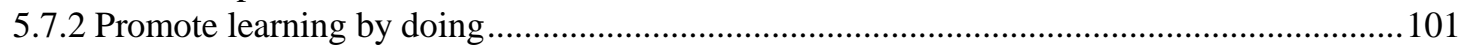

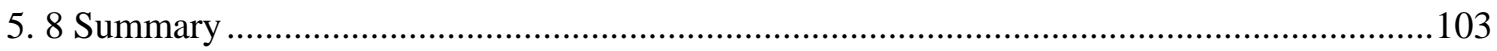

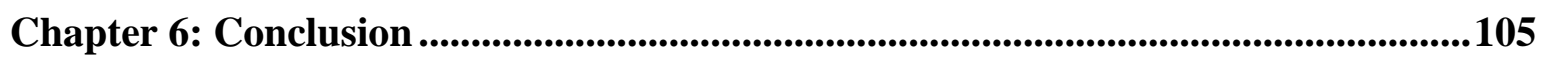

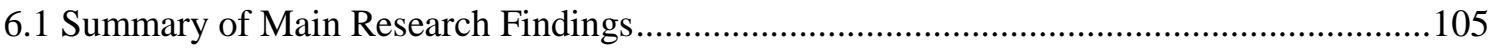

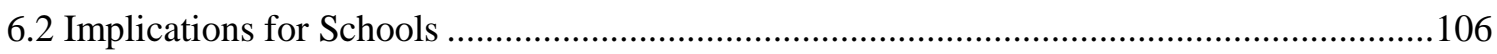

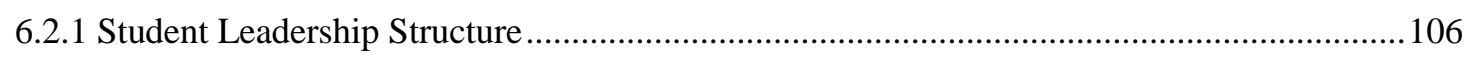

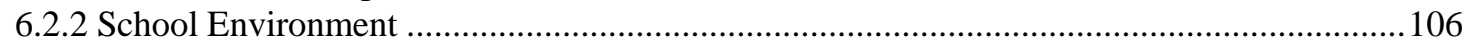

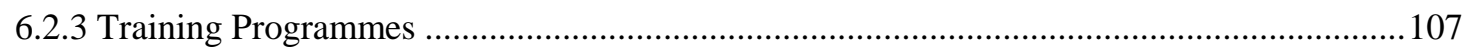

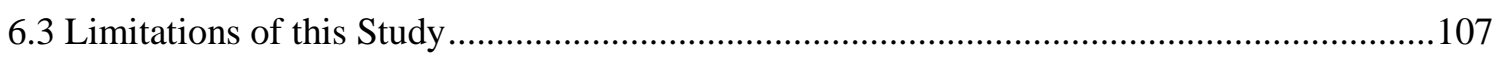

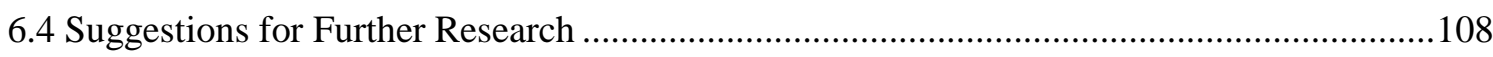

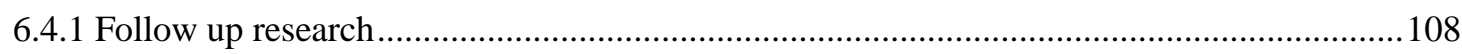




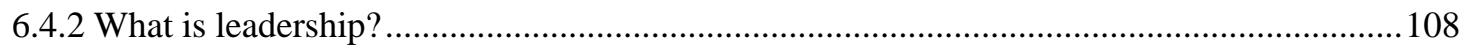

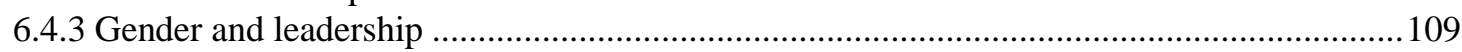

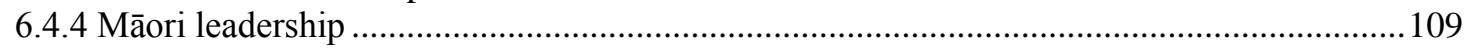

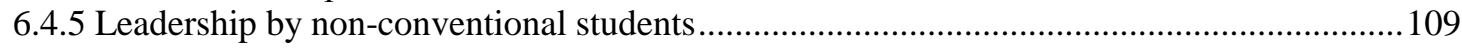

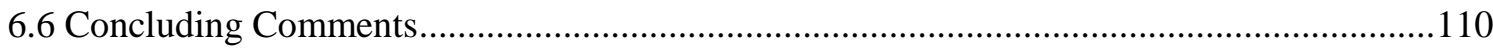

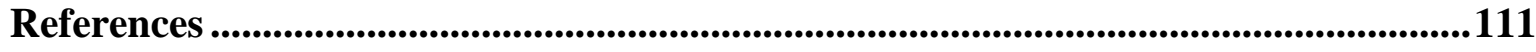

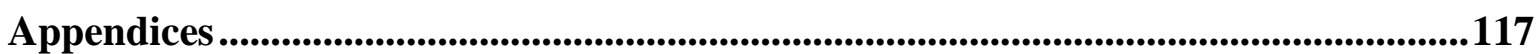

Appendix A: New Zealand Secondary School System...........................................................117

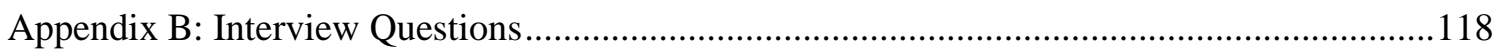

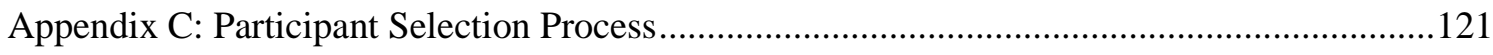

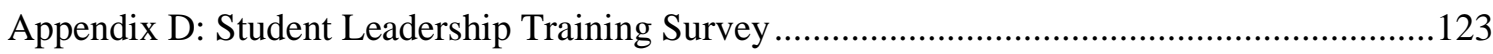

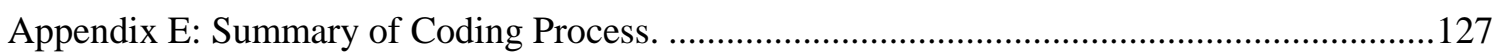

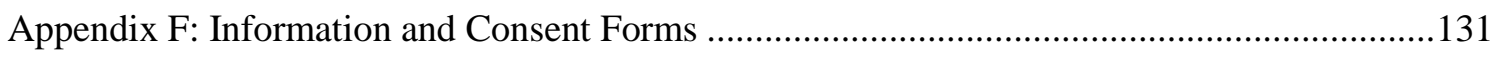




\section{List of Tables}

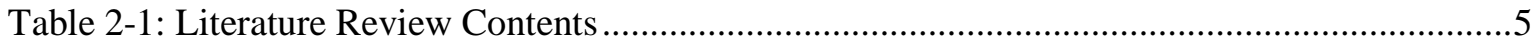

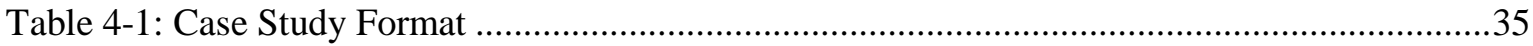

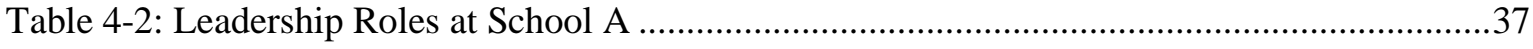

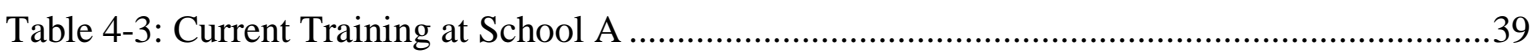

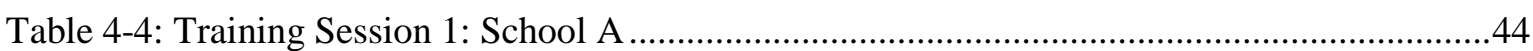

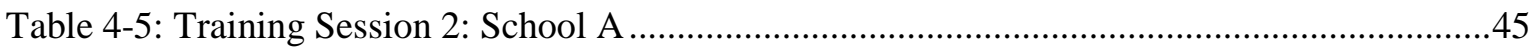

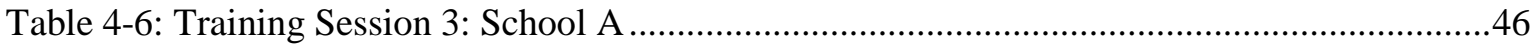

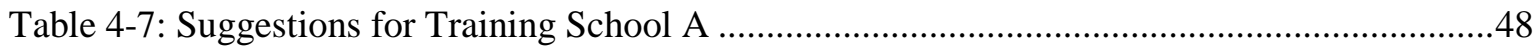

Table 4-8: Community Connections - Prefects' Comments - School A...........................................50

Table 4-9: Community Connections - Student Body's Comments - School A ..................................51

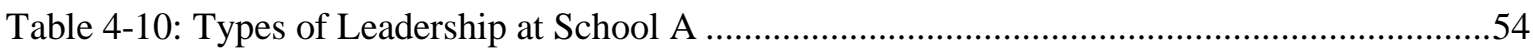

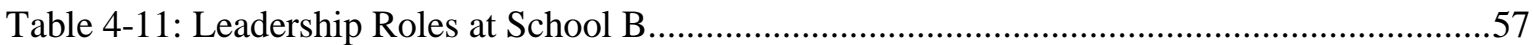

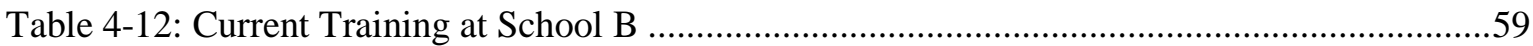

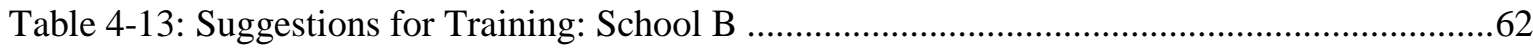

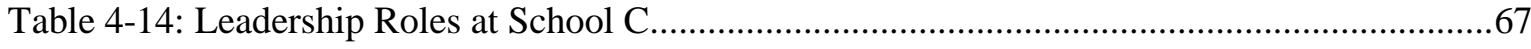

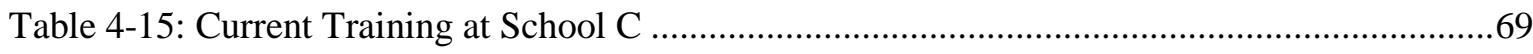

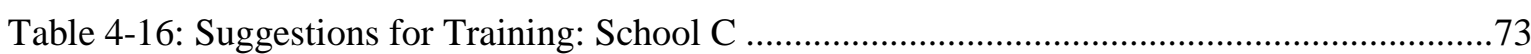




\section{List of Figures}

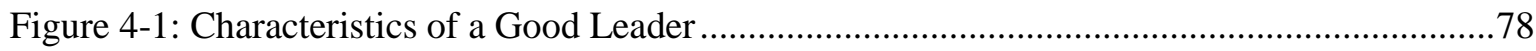

Figure 4-2: Participation in Student Leadership Training............................................................. 79

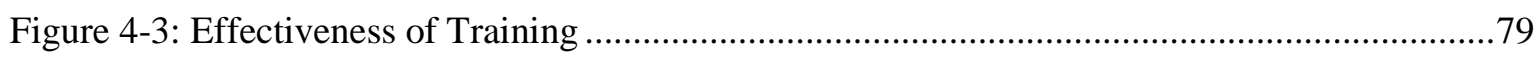

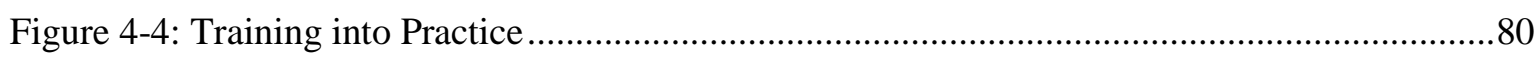

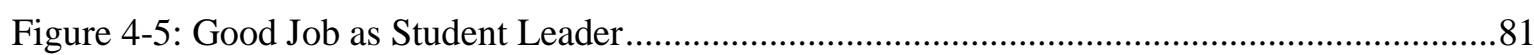

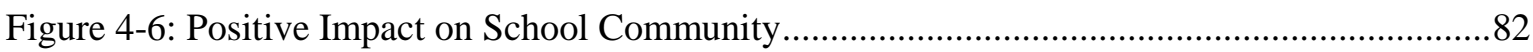

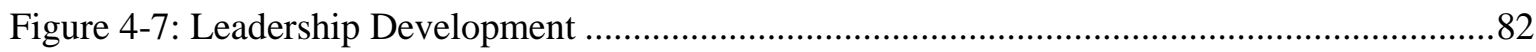

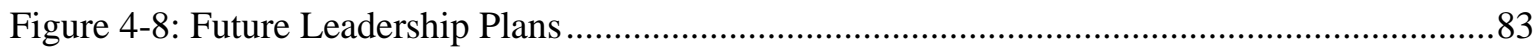

Figure 5-1: Leadership Identity Model (LID) adapted from Komives et al. (2006, p.434) ..............89

Figure 5-2: Model of Leadership Training................................................ 104 


\section{Chapter 1: Introduction}

\subsection{About the Research}

This research investigates what constitutes effective training for student leaders in New Zealand secondary schools. By reaching an understanding of how students can best learn about leadership, schools can develop training that meets the needs of student leaders and the school community. There are gaps in the literature on leadership development regarding how New Zealand schools can successfully train student leaders. This research is based on a multiple-case study of leadership training in three New Zealand secondary schools. A distributed leadership framework is used to investigate the impact of three existing student leadership training programmes. As a result, it is possible to make some recommendations for schools on what they can do in the future to enable and equip students for leadership.

\subsection{Positioning the Researcher}

At the end of each year, in the school where I teach, students apply, are shortlisted, interviewed and then selected to be head students, deputy head students, sports captains, cultural captains, council members and liaison students for the following year. Training is given to these student leaders in early December and at the end of January. I was involved in all aspects of this process in 2008 and 2009 when the students I had pastoral care for were in Year 12 and 13. This experience helped me realise the enormous capabilities students have for leading their peers and making a difference in their school, which led me to this research topic for 2010. I consider that student leaders provide schools with a voice from the student body, a culture of cooperation, direction for the future and action on a daily basis.

\subsection{Rationale for the Study}

In my role as a teacher in charge of student leaders, I have had the opportunity to work with teenagers who have demonstrated vast leadership potential. However, there are many factors that influence how this potential is realised. Of key importance is the kind of training student leaders receive. Student leadership in schools can range from group 
leaders in classroom activities to elected representatives on Boards of Trustees (BOT) ${ }^{1}$. It is likely that the way these students are trained shapes their effectiveness. Student leadership training programmes are run in New Zealand secondary schools in a variety of ways. From my professional experience, I offer the idea that an effective student leadership programme would benefit student leaders and the wider school community. It is important for schools to implement student leadership training that will have positive outcomes.

Research into the effectiveness of student leadership training programmes in New Zealand secondary schools is limited. However, ideas regarding leadership can be taken from other sources and applied to this context. A key theme is that distributed leadership is an effective leadership style for educational settings (Gronn, 2003a, 2003b; Harris, 2008; Spillane, 2006). Research in this area is mainly limited to school management, so it is worthwhile investigating how distributed leadership can be applied to student leadership. This study is also informed by the key premise that leadership can be learnt (Komives, Mainella, Longerbeam, Osteen, \& Owen, 2006; Lambert, 2003; Lavery, 2008; Posner, 2009). Research in this area can therefore be applied to a wide range of students. This study has a number of benefits, including the ability to apply new knowledge to my own situation and develop recommendations for secondary schools who wish to provide effective training for their student leaders.

\subsection{The Aim of the Research}

The overall aim of the research is to find out what constitutes effective training. I have defined training that is effective, for the purpose of my research, in two ways:

- it equips students for leadership

- it enables students to contribute to the school community.

In order to provide insight into this topic and support this aim, I have focused on three key areas:

- how student leaders are trained

- what student leaders gain from their training

- how training impacts on student leaders' contribution to the school community.

\footnotetext{
${ }^{1}$ A Board of Trustees is a group of elected people (parents/caregivers, principal, one staff and one student representative on secondary school boards) who are responsible for the governance of the school.
} 
By looking at these areas, it is possible to see what occurs and what successfully meets the needs of the student leaders as well as the school community.

It is important to discover whether student leadership training programmes encourage students to show leadership. Therefore, the research focuses on what the students' perceive they may gain from their leadership training. To see if programmes impact on the school community, this study investigates whether aspects of leadership that are focused on in the training programmes are then used in leaders' interactions with staff and other students.

This study has theoretical and practical implications for secondary education. It focuses on the experience and reflections of student leaders, and provides insights into what type of training works well when schools prepare students for their leadership role. It allows practitioners to include relevant suggestions for best practice in their training programmes.

\subsection{Structure of the Thesis}

Chapter 1 provides the starting point for the research and an outline of the research aim. It also provides the rationale for the project.

Chapter 2 is the literature review, which outlines issues and key studies in the areas of both leadership in general and student leadership in particular. It explains ideas about distributed leadership that influence the research design and analysis. It also looks at aspects of student leadership training. Gaps in the literature are identified and discussed as a rationale for the research design, explained in Chapter 3.

Chapter 3 explains the methodology used for this research. It summarises and rationalises the research design, focusing on qualitative research and a constructivist theoretical framework. It describes the way data were collected through interviews with teachers, student leaders and members of the student body, as well as through observation and a survey. This shows both the plans and the reality of what occurred. It provides descriptive data about the cases being studied and a summary of ethical considerations.

Chapter 4 presents results in three case study reports and a survey summary. The case study results are reported in six key areas that are common in each school. These are:

1. roles

2. current training

3. effectiveness of training 
4. suggestions

5. community connections

6. types of leadership.

A combination of details, analysis, summary tables and quotes from participants are used in each report.

Chapter 5 is a discussion of six key ideas that emerged from the data. They cover themes that pertain to aspects of both leadership and training. These are analysed in relation to relevant literature.

Chapter 6 provides a concluding summary of the key findings. These include statements from the research that involve implications for schools regarding how to effectively train student leaders. The limitations of the project and suggestions for further research are also discussed.

At each point the writing is guided by a consideration for how these ideas pertain to the New Zealand secondary school context. 


\section{Chapter 2: Literature Review}

\subsection{Introduction}

Many secondary schools in New Zealand run leadership training programmes that are likely to be linked to the roles student leaders are expected to play. In order to understand the types of student leadership training programmes being run and their effectiveness, it is necessary to look at what leadership is and how students are prepared for it. This chapter reviews ideas about leadership, focusing on the effectiveness of leadership training that can be provided to secondary school students. It provides a review of writings on distributed leadership. Attention is also paid to evaluations of leadership training programmes. An outline of the chapter is provided in Table 2-1.

\section{Table 2-1: Literature Review Contents}

\begin{tabular}{|c|c|}
\hline \multicolumn{2}{|r|}{ Literature Review } \\
\hline Section & Content \\
\hline 2.1 & Introduction \\
\hline 2.2 & General ideas about what leadership means in education \\
\hline 2.3 & Current theories about distributed leadership \\
\hline 2.4 & The purpose and impact of student leaders \\
\hline 2.5 & $\begin{array}{l}\text { Training of student leaders } \\
\text { - Why do they need to be trained? } \\
\text { - What kind of training should be provided? } \\
\text { - What skills should be taught? }\end{array}$ \\
\hline 2.6 & $\begin{array}{l}\text { Summary of key ideas } \\
\text { Linking of themes in the literature to this research }\end{array}$ \\
\hline
\end{tabular}

\subsection{Leadership: What is it?}

\subsubsection{General}

Ideas about leadership are constantly changing. The most common contemporary theory about leadership is that all are born with the capacity to lead and can be taught the skills needed to do so. This theory informs recent writing and research on leadership development (Lambert, 2003; Lavery, 2008; Martinek, Schillling, \& Hellison, 2006). 
In his work on changing leadership practice, Peter Gronn (2003a) summarises key developments in perceptions of leadership. He explains that a change in attitude towards leadership ability can be seen as aligning with social change. In European society, the belief that people were natural leaders matched theories of ascription as those born into the aristocracy were seen as becoming leaders by right, based on pedigree. As class systems dissolved, fitness for leadership began to be determined by merit. Gronn explains that a person's actions would determine their suitability for leadership. Both of these methods of attaining leadership were based on the heroic paradigm of a single visionary leader. Then, as education systems developed, leadership came to be seen as something that can be taught and developed through experience, and standards of effective leadership were created. Gronn (2003a) terms this process “customised leaders formation” (p.14).

However, as recognised by Dempster and Lazzio (2007) in their recent review of literature regarding student leadership, further social change has led to a shortage of people willing to take on leadership roles. Also, there is movement away from groups depending on a single leader and towards groups being led by teams whose members share responsibilities and duties. Although there is a current growth in the popularity of leadership teams, there has been little research into their effectiveness, as noted by Gronn.

Alongside a focus on leadership teams, a range of ideas also exist on what constitutes effective leadership. Some of the ideas are summarised here and will be discussed later in an analysis of recent studies. Research based on successful leaders in a range of contexts lists five areas of leadership practices:

- modelling the way

- inspiring a shared vision

- challenging the process

- enabling others to act

- encouraging the heart (Posner, 2009, p. 554).

This shows the all encompassing nature of leadership. A definition of leadership that focuses on context and interpersonal relationships refers to leadership as a "relationship of social influence ... [where ] the object of influence needs to be tied to the core work of the organisation" (Spillane, 2006, pp. 12-13). Recent writing on leadership explains that the leadership qualities that are most valued include collaboration, ethical practices, moral outcomes, credibility and authenticity (Komives, et al., 2006). This leadership style is defined as relational leadership: "a sense of self as one who believes that groups are 
comprised of interdependent members who do leadership together" (Komives, Owen, Longerbeam, Mainella, \& Osteen, 2005, p. 608). This explanation is compatible with the drive in many work and community contexts for team leadership and equal responsibility.

\subsubsection{School Leadership}

In line with recent writing on leadership in schools, and as referred to in the previous section, there is a growing dissatisfaction with single visionary leaders. Interest is now on alternative models that allow for collaboration, interdependence and diversification in order for schools to find a leadership model that is appropriate for their particular context (Spillane, 2006). Research into leadership in secondary schools is extensive with regard to teachers and management. Busher (2006), Davies (2005) and Robinson, Hohepa and Lloyd (2009) contribute to knowledge and understanding in this area. Busher writes from a background of research in England, including ethnographic research into subject leaders ${ }^{2}$ and asserts the importance of collaboration and negotiation. In his investigation of leadership, he critiques the use of power in school settings. Davies draws on his research findings from case studies on school leaders and focuses on the necessity of strategic leadership, including direction setting. He suggests that this involves allowing everyone in the school to contribute to the school's future.

In the New Zealand context, in their summary of a recent synthesis of research, Robinson, Hohepa and Lloyd (2009) refer to 27 studies that quantify the relationship between leadership and student outcomes, and conclude that leadership should be focused on teaching and learning for improved student outcomes. Timperley (2005), also working in New Zealand, conducted research on leadership in schools implementing a school improvement initiative. She looked at seven primary schools implementing a literacy programme and identified risks and benefits for schools using distributed leadership. Distributed leadership is a group leadership model that focuses on the interactions between leaders, people around them and their situation. It will be discussed further in section 2.3. New Zealand secondary schools are currently focused on leadership that promotes an environment where everyone is a learner, working together to improve teaching practice and raise student achievement (Lee, 2006).

\footnotetext{
${ }^{2}$ The New Zealand term for a subject leaders is a Head of Department (HOD)
} 
A useful case study on a co-principalship initiative in a New Zealand primary school focuses on mutual accountability and responsibility when leadership is shared (Court, 2004). The teachers in Court's case study reacted against the hierarchical expectations in the Tomorrow's Schools' legislation (New Zealand. Department of Education, 1988) and with the support of their board of trustees developed a shared management model that allowed for collaborative planning and decision-making. As management workload increases and as schools are seeking to retain skilled teachers, there is more acceptance of flat leadership structures. An acceptance of change in leadership structure has grown, as shown from 1995 when the State Services Commission deemed co-principalship illegal, to 2002 when the Ministry of Education endorsed the practice (Court, 2004).

These ideas show that school leadership impacts on student outcomes. They show that schools can reject hierarchical systems and base themselves on leadership models that allow for collaboration.

\subsubsection{Student Leadership}

Research into student leadership appears limited. Dempster and Lazzio (2007) and Roach et al. (1999) highlight that much more information is needed on what young people believe leadership to be, where they think it is needed and who should be involved. Dempster and Lazzio suggest that we let students explain what leadership identity development involves. Overseas studies have focused on how student leaders act (Kezar, 2000; Lavery, 2006; Martinek, et al., 2006). Positive student leadership is seen as occurring when students develop a service mentality and show compassionate leadership. These conclusions are drawn from observation and experience. However, conversations with student leaders, while they are in positions of leadership, seem lacking.

Cartwright (2005) writes from twenty years' experience of setting up peer support programmes in schools in the United Kingdom and emphasises that students can work with others to help them learn and develop in many areas - emotionally, socially and academically - to reach their full potential. She has trained students in leadership roles to run support groups, co-counselling clubs, drop-in counselling, mediation, playground support and to act as mentors. She sees student leadership as based on trust and taking a risk by sharing with, or delegating power to, young people. This focus on collaboration fits with distributed leadership theory (Spillane, 2006) and, in order to replicate Cartwright's success, could be successfully adopted by New Zealand secondary schools. 
Komives et al. (2006) directed a grounded theory study that involved interviewing thirteen university students who showed relational leadership qualities, and have defined the process of leadership identity development. They provide a useful explanation of how this occurs: "leadership development involves engaging with leadership opportunities over time to build one's capacity or efficacy to engage in leadership" (Komives, et al., 2006, p. 402). These authors explain that people are seen to progress through six stages as they develop their identity:

- $\quad$ stage one - awareness

- stage two - exploration/engagement

- stage three - leader identified

- stage four - leadership differentiated

- $\quad$ stage five - generativity

- $\quad$ stage six - integration/synthesis (Komives, et al., 2006, p. 404)

At the final stage, students see themselves as working effectively with others and have the confidence to do that anywhere.

Young people today are more interested in leaders who work together with followers. Of primary interest is a person's ability to build relationships showing trust and respect. This idea is confirmed by an American study involving 30000 young people taking part in 120 non-school, youth-based organisations (Roach et al., 1999). The study found that, because of the range of demands in the projects undertaken in these organisations, there was unlikely to be a single leader. Leadership is likely to be distributed among many. Roach et al. make the important observation that we lack awareness about how young people define and initiate leadership among themselves. But what they have observed is that the focus does seem to be in doing leadership not being a leader. "Self knowledge and commitment to relationships that sustain group goals, along with skills necessary for constant collection and assessment of information, stand as dominant in youth leadership" (Roach, et al., 1999, p. 21). An observation of note for educators is their conclusion that young people value three types of leadership: shifting, emerging and mutual. These findings can inform student leadership training.

Although the New Zealand curriculum encourages schools to provide opportunities and support for student leadership (Ministry of Education, 2007), research on student leaders in New Zealand secondary schools is limited. The New Zealand Ministry of Education ("Ministry of Education," 2009), New Zealand Council of Educational Research 
("NZCER," 2009) and Te Kete Ipurangi - The Online Learning Center ("TKI," 2009) websites refer to programmes that have been implemented recently to meet the requirements of the New Zealand curriculum's new key competency ${ }^{3}$ of participating and contributing (Ministry of Education, 2007), and programmes to develop the curriculum area of Health and Physical Education. However, these programmes are primarily focused on students in the classroom rather than students who have leadership responsibilities outside the classroom.

Peer support has been running in New Zealand secondary schools since 1985. It is a programme designed for older students to help younger students build self-esteem and relationship skills. Two Year 13 students are typically matched with a small group of Year 9 students and run eight sessions on relevant topics like friendship, bullying and selfawareness.

An evaluation of the programme consists of a survey sent to all secondary schools and a case study of interviews in one school (Hynes, 2006). There was a 59\% response rate to the survey. Of those that replied, $68 \%$ ran a peer support programme. Hynes' evaluation is useful as it shows how and why schools train students to be peer support leaders. Most schools provide a two-day training course for their leaders, followed by regular meetings to plan or debrief when the programme is running. Schools comment that the key aims of the training are leadership development, building communication skills and giving students practice at being a leader. Hynes' discussion regarding student leaders concludes that teachers need to provide ongoing support and training.

Hynes' research does have some limitations in that she is an involved and supportive advocate of the programme, doing an evaluation on her own that may have led to some researcher bias. Involved with peer support since 1993, she has worked as a peer support trainer at a regional level and was involved on the editorial team for the revised peer support manual published in 2004. She does not mention any peer review processes in her report. Although she invited all secondary schools to complete her survey, she only used one school as a case study. This included five student leaders and five Year 9 students, though she comments that, in the year of her research there were likely to be 5546 student

\footnotetext{
${ }^{3}$ The New Zealand Curriculum, which was written in 2007 and will be fully implemented by 2011, includes a focus on key competencies that are defined as capabilities for living and lifelong learning: what people use to be active member of their communities.
} 
leaders and 21495 younger students participating in the programmes. She recognises that her case study was a "personal snapshot” (Hynes, 2006, p. 48), and that more interviews in different types of schools would provide a better overview of peer support throughout New Zealand.

It is also possible to examine overseas programmes that focus on mentoring. Archer (2008) has developed a useful model entitled CAMP (Cross Age Mentoring Program) for school counsellors in America to use when training and supporting high school students in mentoring elementary school students. He explains that cross age mentoring can develop leadership and collaboration skills in high school students and provide younger students with guidance, social support and academic assistance. The Rite Journey programme in Australia matches boys with adult mentors (Lines \& Gallasch, 2008). When the boys are in Year 9 they also mentor junior students. After being trained in how to help learner readers, they are buddied with a junior reader with whom they work once a week. This is seen to encourage maturity and leadership skills.

To summarise, student leadership involves collaboration and service for the school. Leadership is usually shared and helps students develop a leadership identity. It is based on relationships of trust and seen as a process rather than a role. Popular forms of leadership include peer support and mentoring.

\subsection{Distributed leadership}

\subsubsection{What is it?}

The theory of distributed leadership encourages a view of the importance of collective interactions between leaders, people around them and their situation (Harris, 2005; Spillane, 2006). First used by Australian psychologist Cecil Gibb in 1954, the term distributed leadership was used to refer to leadership as a group quality. Gibb explained that leadership is taken by different individuals within a group at a certain time in response to situations and needs. It is a framework for analysing leadership that recognises the importance of the context of leadership and not just the actions of leaders. This allows for research on leadership to focus not just on what leaders do, but on how they lead in their environment. The focus is on lateral leadership as well as the dynamic interactions between multiple leaders and others in their context (Harris, 2008; Timperley, 2005). It is a move away from the hero paradigm that views leadership as being done by one extraordinary person. In education, the focus is on a school's overall capacity for leadership, rather than 
an interest in, one person as leader (Gronn, 2003a). Distributed leadership has been aligned with transformational leadership where structures are in place to promote participative decision-making and delegation (Lee, 2006). As recognised by Spillane (2006), there are few frameworks for studying leadership practice. By using a distributed leadership framework for research it is possible to focus on the interactions between what Spillane terms leaders, followers ${ }^{4}$ and their situation.

\subsubsection{Distributed Leadership for Student Leaders}

Some researchers in the field of leadership suggest that distributed leadership is the best model of leadership for schools as it allows for collaboration and both lateral and vertical leadership structures (Gronn, 2000, 2003a; Harris, 2005; Timperley, 2005). Gronn (2002a) recognises the existence of interdependent role behaviour that allows leaders to make the most of their individual strengths. He also suggests that synergy (creative tension) is inherent in distributed leadership as boundaries are blurred and expanded involving all those in the leadership context. As previously mentioned, current secondary school students are not interested in heroic models of leadership and are more interested in leaders who work with the student body rather than at a distance (Dempster \& Lazzio, 2007).

Researchers looking at peer education (a form of student leadership) in drug prevention teams in the United Kingdom conducted observations and semi-structured interviews to complete case studies in five different projects. One of their key findings was that the situation is a key factor for success (Shiner, 1999). If students were able to work outside of the school environment, without teacher intervention, they felt better able to achieve their goals. For success, the approach needed to fit with the location as well as the needs and situation of the people involved.

Distributed leadership matches the focus young people have on shared leadership. Research indicates that they see leadership as give and take between leader and audience (Roach, et al., 1999). The importance of situation is also emphasised by Roach et al., who note that youth value wisdom in spontaneity, when a person is able to size up the situation

\footnotetext{
${ }^{4}$ The term follower is used by Spillane (2006) in his work on distributed leadership to signify those that follow someone's leadership. For my study, this is likely to be students at the school. As the term is rejected by some working in the field of distributed leadership, I will be more specific and refer to these people as the student body.
} 
and step forward or back to make progress. The situation is seen as pivotal, along with group alliances and relationships.

School reform is seen as more successful if students participate. Those involved in research regarding student voice advocate for the concept of distributed leadership in education to involve both students and teachers (Mitra, 2005). As a leading figure in research using the framework of distributed leadership, Spillane encourages the use of a distributed leadership framework as both a "diagnostic tool for reflecting on leadership practice and a design tool for thinking about the improvement of leadership practice" (Spillane, 2006, p. 8). These ideas are equally useful for this study with its focus on how student leaders reflect on their training and on the effectiveness of the training they receive. This may lead to suggestions for improvement.

This framework will be used to direct the research to see if student leadership training recognises the school community and equips students for the social interactions they will have, rather than the jobs they will do. This will influence the research design and methods of data collection. Ideas have developed that suggest leadership is about shared, purposeful learning in community (Harris, 2008; Lambert, 2003). This wide lens for looking at leadership fits with a constructivist paradigm as it allows a range of perceptions about leadership to be included. This paradigm can be seen as useful for bringing about change. It enables exploration of student leadership training and the development of a theory about what is effective training. Findings can then be applied in school contexts.

\subsection{Student Leaders}

\subsubsection{Why have them?}

Writing on students as leaders is concerned with describing the kind of leadership that is promoted by schools. It is important to note that student leaders are seen as having an impact on school culture (Busher, 2006; Whitehead, 2009). In recognition of this, Busher explains that, in England, students are given roles on governing bodies. In a similar way New Zealand secondary schools have involved students in issues of governance since 1989 when Boards of Trustees were established with student representatives ${ }^{5}$. While Busher sees this as a positive move towards the kind of leadership students should have, Lambert

\footnotetext{
${ }^{5}$ These student leaders are usually referred to by schools as the BOT student rep, which is the term used in the remainder of this thesis.
} 
(2003) and Neigel (2006) highlight the concern that student representation on school boards is becoming a token gesture rather than a real avenue for leadership and for the student voice to be heard. In this regard, it will be useful to conduct research into whether the training given to student leaders prepares them for their role and allows them to have an impact on the culture of their school, rather than be leaders in name but not in practice.

Peer support can be seen as part of student leadership. The requirement for schools to protect young people and promote their emotional wellbeing, in accordance with the United Nations convention on the rights of the child, led to peer support programmes being developed and used internationally. Programmes began in North America in the 1960s and are now used in schools who aim to create a safer and more supportive environment, and are often linked to anti-bullying strategies (Bishop, 2003). In 2007, a survey of 240 schools in the United Kingdom led to an adjusted sample estimate that $68.5 \%$ of all United Kingdom secondary schools have a peer support scheme. The most common forms of peer support in secondary schools are mentoring and befriending, and may also involve mediation and counselling. These leaders are seen to give support, help and guidance to students and to contribute positively to the whole school ethos and environment (Houlston, Smith, \& Jessel, 2009). Two-thirds of New Zealand secondary schools run the Peer Support programme, which aims to "promote personal development in the helpers, to use peer helpers in the role of caring support for peers and to produce a positive influence on the emotional climate of a school" (Hynes, 2006, p. 11). The longevity of the programme implies it is valued by schools and communities.

Research confirms that student leaders can enhance levels of affiliation of all students, and supports the earlier suggestion that leaders provide a voice from the student body and improve overall school processes (McGregor, 2007; Neigel, 2006). Neigel's evaluation of a student government association that has been running in his American high school for ten years advocates the process used in his school where students choose a problem to research, investigate and recommend changes. This enables students to influence and support school-wide change.

Research also suggests that, if student leaders are committed to academic achievement, the rest of the school will accept studying hard as the norm (Smith \& Piele, 2006), This shows the potential that leaders have for shaping school culture. Student leaders have been seen to influence student values, attitudes and actions for the good (Lavery, 2006). 


\subsection{Training Leaders}

\subsubsection{Purpose of Training}

As recognised by school leaders, opportunities abound for the practice of leadership by students (Moore, 1999). Martinek et al. (2006) completed research through interviews and observations into two education programmes designed to foster youth leadership amongst low-income, minority youth in Chicago. They identified three main opportunities to learn about leadership: through trial and error (learning by doing), people (role models) and education (leadership training programmes). Education is seen as a way to encourage and enable all students to lead.

Following Komives et al.'s (2006) research and leadership identity development (LID) model (as outlined in section 2.2.3), secondary school students are most likely to be at stage three - Leader Identified. They see leadership as a position, holding leader-centric and hierarchical views of leadership. Their belief is that a leader is there to get the job done and be responsible for group outcomes. At the next stage of Leadership Differentiated, students see leadership as a process that could come from anywhere in a group. Komives et al. see schools as having the potential to guide students through this key transition. They recommend both challenging and supporting students, designing group projects, teaching the language of leadership and encouraging reflection. Key components also include relating to diverse peers and having an adult mentor. Komives et al. (2005) include a useful summary of key developmental influences: adults, peers, meaningful involvement and reflective learning which schools can seek to include in leadership training programmes.

Lambert (2003) also suggests that leadership and learning are linked and that all learners have the capacity to lead. Writing from a constructivist paradigm, Lambert's suggestion is that leaders contribute to the school and their community through service as leaders, building personal resilience as well. This idea stems from research into classroom-based activities. It will be useful to see if this same sense of contribution and service is gained from student leadership training programmes in New Zealand. Writing from a Catholic educational background, Lavery (2008) also concludes that all students have the ability to be leaders. Of the 368 students he surveyed, 314 (85\%) believed all students in their final year of secondary school should be given leadership opportunities. So this idea is supported by the students who are trusted and trained to lead. Dempster and Lazzio (2007) refer to an Australian high school that provides leadership development for all its students 
for five years. The school notes an enhanced engagement of students with their school, a continuing commitment to learning and good relationships between school management and students.

Those surveyed regarding peer support training (Houlston, et al., 2009) see the benefits for those acting as mentors as wide-ranging especially with regard to skill development as their social, empathetic, communication, interpersonal, leadership, listening and life skills are seen to grow. Houlston et al. also reported that students gain greater self-esteem and self-confidence and take on increased responsibility within the school.

Lavery also provides useful suggestions about using service learning ${ }^{6}$ to enhance leadership training programmes, seeing service learning as aiding personal growth in future leaders and developing life skills. From the perspective of a school principal, Moore (1999) corroborates the idea that as leadership skills can be learnt it is beneficial for all students to be given a basic understanding of leadership and training. Posner's (2009) longitudinal study into the impact of formal leadership programmes on students' leadership development concludes that students who partake in leadership training while doing tertiary study see positive change in their educational achievement and personal development. Posner also writes from the position that there is leadership potential in every student.

Dempster and Lazzio (2007) however, provide a reasonable criticism of Posner's study for using adults' concepts of leadership rather than using students' perspectives, as Posner's survey instrument used words and phrases about leadership originally proposed from research in corporate contexts. Dempster and Lazzio do concur with Posner's suggestion that research into how leadership development occurs is necessary and beneficial for those training both students and adults.

Mitra (2005) also highlights the lack of research into how adults can both give support and create space for students to take responsibility for school improvement. From her research in two schools that do make use of the student voice, Mitra suggests that teachers can share group leadership with students when research and planning are being completed.

\footnotetext{
${ }^{6}$ Defined by the Australian Catholic Centre for Service and Leadership as a teaching method that combines community service with academic instruction.
} 
In summary, a key suggestion is that all can lead. Student leadership training has personal benefits for students, helps them develop a leadership identity and allows them to contribute to their school.

\subsubsection{Leadership Training Programmes}

As previously mentioned, the current general consensus is that leaders are made, not born, and even those who appear to have natural leadership qualities actually gained them from a learning process (Martinek, et al., 2006). Systematic preparation for leadership is more valuable than chance experiences and more likely to develop effective leaders (Bush, 2009). This supports the case for New Zealand secondary schools to develop well-planned leadership training programmes and to teach the skills student leaders will need to fulfil their role. Research suggests that young people are more likely to see leadership as a group activity rather than linked to personal skills and development, therefore leadership training based on adult models is unlikely to be as effective as training that is based on distributed leadership theory (Roach, et al., 1999). Roach et al. suggest students should be trained so as to be able to observe, act and assess in a group situation.

Although based on research into the role of school leaders, Bush's conclusion, that when designing leadership development programmes, it is important for the training to form a bridge into the person's work as a leader, is also applicable for student leaders. Posner (2009) concurs and suggests leadership is much more useful than learning about leadership. This leads to questions for the New Zealand context: does the training provided to student leaders have immediate and practical application? Does it equip and enable students to show leadership?

In the United Kingdom the peer support training for students is designed to take three days. Students are taught listening and counselling skills, focusing on re-evaluation counselling techniques ${ }^{7}$. Students observe demonstrations of counselling and then practise counselling. They also learn games and about the practicalities of setting up peer support (Cartwright, 2005). A key element of the training is to establish regular supervision from trained staff. Although not detailed in Hynes' evaluation, peer support in New Zealand runs along similar lines. Teachers in schools train and support senior leaders. The most successful

\footnotetext{
${ }^{7}$ Re-evaluation counselling is done in pairs by people listening to each other and helping each other to release painful emotions.
} 
peer support training programmes have a teacher responsible for peer support who develops a programme relevant for their school and students, provides ongoing support and training, focuses training on how to run group work and affirms their student leaders (Hynes, 2006).

The suggestion from the literature is that leadership programmes should be customised to each situation and made relevant to the students' world. It should be integrated with learning and have practical applications (Whitehead, 2009). It has been suggested that, because many school principals no longer teach in the classroom, they should align themselves with the student leadership training programme in their school to have an impact on the learning process of this group (Freeborn, 2000).

New Zealand research on the kind of leadership training all students need, has led to the development of student-led health projects. Tasker (2004) has developed an action competence model where students can take individual or collective action. Though leadership is an aspect of this model, most of the focus is on the critical thinking skills of the participants. Sport and Recreation New Zealand (SPARC) also promotes leadership through its Growing Leaders resource ("SPARC Growing Leaders.," 2009). This provides a comprehensive range of activities to train leaders, but is not a specifically school-based programme.

As previously mentioned, many schools develop and implement a leadership training programme based on the needs of the student body. Kate Brown, working as a counsellor in an Australian school, shows the benefits of this approach in the student leadership training programme she developed to bring about personal change (Brown, 2003). Her programme, entitled SMART, uses peer mentors to model words and behaviour based on self-belief. Senior students conduct five sessions with junior students based on goal-setting and are debriefed after each session, providing them with ongoing support.

Mitra (2005) observed effective training in schools when students were allowed to take on leadership roles, including planning meetings. They were able to experience leading their peers in an authentic context as student groups developed to contribute to school reform and shared decision-making with teachers and management: an example of distributed leadership. Mitra's research proves that it is important for teachers involved in student leadership training programmes to decide how they will act - as an advisor, guide, instructor or boss. The role the teacher plays depends on whether they adhere to a 
hierarchical or distributed concept of leadership. Mitra suggests that the best role a teacher can play is as a supporter, allowing for trial and minimising error.

Mentoring in some New Zealand schools has been linked to a traditional concept from Māori society called tuakana-teina. This is when the older and more experienced tuakana (big brother, sister) guides and assist the younger teina (younger sibling). The tuakanateina model for mentoring has been identified as a strategy that helps schools respond effectively to students from diverse backgrounds (Alton-Lee, 2003).

Those involved in the Big Brothers Big Sisters (BBBS) mentoring programme ${ }^{8}$ in America recognise that school counsellors often develop their own programmes because of a lack of materials on how to run mentoring programmes. BBBS usually matches adult volunteers with young people, and schools have used the BBBS resources to train teenage mentors in the same way. Karcher (2008) emphasises that, because of developmental factors a different approach is needed when training high school mentors. He suggests that in the school context mentors and mentees benefit most from a highly-structured programme. His CAMP (Cross Age Mentoring Programme) model, described as a strengths-based intervention for promoting developmental competencies, shows school counsellors how to design and evaluate a programme and to train mentors. Karcher suggests that the key focus for a programme should be on promoting connectedness to self, others and society. The training for mentors focuses on how to provide empathy, praise and attention within a clear, consistent structure. Mentors should also be encouraged to think about the developmental needs of their mentee and to adjust their interactions and conversations accordingly. Karcher provides a useful reminder that mentoring is unlikely to just happen successfully after students are matched up - schools need to be committed to ongoing training and providing a context for mentoring interactions to occur.

Research by Walker and Avis (1999) based on a literature review and personal experience from the design, implementation and evaluation of 12 peer-led projects, highlights the importance of clearly stated aims and objectives when training those involved in peer education. They also suggest process and outcome evaluation to establish if the training has been effective.

\footnotetext{
${ }^{8}$ Adult volunteers are matched with children from the ages of 6-18. It is the largest volunteer mentoring programme in America. It was started in 1904 and now operates in 12 other countries as well ("Big Brothers Big Sisters," 2010).
} 
In summary, training student leaders is necessary and best done through a process that encourages and facilitates distributed leadership. Training should be designed specifically for the leadership context and should respond to the needs of the individual school. Teachers take on the role of supporter as students learn to lead. Training should also be based around providing opportunities for students to practise showing leadership.

\subsubsection{Skills Taught}

Research based on case studies in a youth leadership programme run in Chicago for adolescents from low-income backgrounds has developed a useful outline of the stages of youth leadership development (Martinek, et al., 2006). Students are seen following a transformational process from needs-based leadership to focusing on planning and teaching, then reflective leadership, and ultimately to compassionate leadership. The goal of compassionate leadership is perhaps the aim of many running leadership training programmes - that leaders internalise an ethical concern for relationships with others. This links to ideas around distributed leadership where the focus is often on personal interactions.

Those evaluating peer support systems in the United Kingdom note that students trained in this area are taught skills based on providing empathy, understanding and practical support to help them resolve a wide range of problems. They learn how to work in pairs, handle emotions, resolve conflict, lead and use a support group and how to use games to build self-esteem. They also gain an understanding of issues around confidentiality, sexism, ageism, racism, disability and harassment (Cartwright, 2005). This focus on skills and knowledge prepares students well for the school situation and for life beyond school.

Research completed in America with those that teach tertiary students elected to represent others identified that the leadership qualities teachers value and teach most to these students include: teamwork, being a role model, setting personal or team goals, commitment, cooperation, ethical leadership, solving problems and effective listening (Boone \& Taylor, 2007). The research concluded that teachers should be involved in the neverending process of providing leadership education, training and experience.

Australian research on students in their last year of secondary school also emphasised the value of encouraging student leadership, primarily as it promotes service (Lavery, 2006). Lavery surveyed 368 Year 12 students in three secondary schools for their perceptions of 
student leaders. He lists service as the first of six underlying principles for student leadership. The others being to:

- promote the good within the school

- empower through activities involving group participation

- encourage students to recognise the power they have to make a difference

- train and develop all senior students

- have adult mentors to work with students.

Lavery suggests this will lead students to anticipate areas of need, be proactive and inspire confidence as they believe in themselves and others. A school principal (Freeborn, 2000) has recognised student leadership as evidence of the informal thinking curriculum of a school linking in with the aim of schools to encourage lifelong learning. He suggests that the skills student leaders should be taught include public speaking, how to widen their communication network, time management and negotiation. If student leadership opportunities are offered in the junior school and students are trained at this level, many of these skills will be established before students are elected or chosen to lead in their last year of school. This could be an effective component of leadership training.

Training for student leaders focuses primarily on interpersonal skills. These involve building compassion, confidence, a service mentality and problem solving skills.

\subsection{Summary of Relevant Literature}

This literature review has focused on two key areas: contemporary ideas about leadership, and strategies around training student leaders. Distributed leadership is recognised as an effective model for schools that can be applied to student leaders. It allows for their leadership to be shared by many and shaped by the situation. Student leadership training has been shown to be personally beneficial for student leaders (Komives, et al., 2006; Posner, 2009) and also to benefit the school community (Lambert, 2003; Martinek, et al., 2006) as school culture improves. From the literature, training can be seen to be worthwhile, especially when it is context-specific and allows for learning about leadership by doing leadership.

This initial review of the current literature suggests there are gaps in the body of research on student leadership, training methods and their effectiveness. Therefore, the specific area to be addressed in this study is the identification of some methods of training and exploration of its effectiveness in New Zealand secondary schools. The existence of this 
gap shows that research in this area would be useful for schools. Filling this gap may lead schools to evaluate the training they are currently offering in light of the research findings. They may choose to implement some suggestions from the research about what constitutes effective training that may meet the needs of the school and the students. My literature review has led me to question whether the training being conducted at this time is responsive to emergent ideas on leadership, and how we can effectively train student leaders for their important roles in school life. This is likely to benefit staff and students, and at a broader level, schools in general. 


\section{Chapter 3: Methodology}

This chapter explains the methodology and methods for my research. It begins by outlining the research questions as shaped by the literature review, which leads into an overview of the theory that informed the methodological choices. This forms the research design and is followed by a description of the research process. This allows me to show my plan of action and then that plan in action. The methods of data collection and analysis are then explained. This is followed by sections that address issues around validity, reliability and ethics. The chapter concludes with descriptive data on the research sites, foregrounding the results chapter.

\subsection{Research Questions}

One key question and three supporting questions guide this research:

\section{Key question:}

What constitutes effective leadership training in New Zealand secondary schools?

\section{Supporting questions:}

1. What is the nature of the training given to student leaders?

2. What do students gain from the leadership training?

3. How does training impact on students' contribution to the school community?

The framework of distributed leadership is used to shape the research process to look at the leadership training context. It is intended that this research will be useful for those planning and implementing student leadership programmes in secondary schools. As schools concentrate more on the new key competency in the curriculum of participating and contributing (see footnote 1), these programmes may reach into all year levels.

From my professional experience prior to commencing this research, I expected schools to use a training programme that aims to equip students to perform their leadership tasks and fulfil their leadership role. I suspected training to be provided by members of the school community and to be focused on meeting the needs of the school. My hypothesis was that effective leadership training programmes will support leaders throughout the year and be responsive to both the individual needs of the leaders and to the specific needs of the school. This research seeks to determine whether this hypothesis can be supported from the experience of student leaders. 


\subsection{Research Design}

This outline explains the type of research and theoretical underpinnings that are used to answer the research questions.

\subsubsection{Qualitative Approach}

This section explains why I have chosen a qualitative rather than a quantitative approach.

\section{Interpretive paradigm}

The research is situated in the interpretive paradigm, which is based on a concern for the individual and attempts to understand the subjective world of human experience (Cohen, Manion, \& Morrison, 2000). As suggested by Cohen et al., research in this paradigm starts with individuals and aims to understand how they interpret the world around them, from which a theory will emerge that makes sense to the subjects of the research. It is also possible, when working in this paradigm, to gain insight into people's behaviour. This suits my research aims as I seek to learn what constitutes an effective programme and why.

\section{Qualitative approach}

The research questions are focused on how students and schools approach and experience leadership training. Literature on research paradigms (Bogdan \& Bilken, 1997; Punch, 2005) clearly places this study in the qualitative tradition. The research is qualitative as it is based on explaining the experiences of student leaders. This focus on experiences means that interest is in how individuals interpret their leadership training. This knowledge needs to come from the inside and therefore relies on the voices of the participants. Quantitative research is often based on experimental designs, gaining empirical knowledge, detached observation and statistical description (Bogdan \& Bilken, 1997), which are not always useful when asking participants to reflect in their experiences. Quantitative research may also focus on the measurement of causal relationships between variables (Denzin \& Lincoln, 2005), whereas this project is more interested in how situations in the training of leaders are developed and given meaning.

\section{Constructivist theoretical framework}

A constructivist theoretical framework is used because it recognises the inner experiences and individuality of the participants (Cohen, et al., 2000). This approach follows the theory that there are multiple realities (Denzin \& Lincoln, 2005). As a result my interest is in the participants' views of the situation and the range of ideas that come from individual 
interpretations (Creswell, 2008). The research is also focused on the leadership situation and understanding the environment where leadership is shown which stems from this theoretical framework and matches ideas about distributed leadership. Constructivist research also recognises the background of the researcher (Creswell, 2008) because it will influence the interpretation of results. I have included some of my background, including some of my preferences regarding student leadership training in the introduction. A constructivist research framework also influences the way that the data are approached as it works from the position that theory, though influenced by personal experience, is developed inductively. This process is explained further in the section on data analysis to show how theory development is influenced by personal experience, literature and primarily from data collection. I am interested both in specific experiences and how aspects of these can be applied to other situations. This involves some generalisation. Patton's (2002) comments on constructivism suggest that research conducted in this framework cannot be generalised from one situation to another, however; by using a multiple-case study method which includes looking at commonalities across all three schools, some conclusions can be generalised.

\subsubsection{Case Study Method}

This research is a multiple-case study to assess how three different types of schools train their leaders. In accordance with Yin's basic types of designs for case studies (2003), I have adopted a holistic design based on a single unit of analysis in a multiple-case study that investigates three cases (student leadership training) in three contexts (three schools). The case study method is appropriate as the research is based on a detailed examination of a series of related events (Mitchell, 2000). The series of related events are the instances of student leadership training. Case study research is also recognised as a suitable method for those working in a constructivist framework (Creswell, 2008). It is also a method linked to program evaluation as it shows successes and failures on the way to the final outcome (Patton, 2002). Yin (2003) explains that case study research can look at the link between programme implementation and effects, which matches the focus of my research questions.

For the purpose of this research, the experience under investigation is student leadership with a focus on training. Creswell (2008) explains that a case is bounded by time and activity. The boundaries are those involved in student leadership at each school in 2010. Case studies enable unique examples of real people in real situations to be seen to establish cause and effect, as well as to observe effects in real contexts (Cohen, et al., 2000; Yin, 
2003). The design of this case study is explanatory to discover how student leaders can be effectively trained. Case studies are also useful when "the boundaries of the phenomenon and context are not clearly evident" (Yin, 2003, p. 13), which is the case for this research topic as student leadership is always tied to the school context. As stated by Cohen et al., the aim of a case study is to show what it is like to be in a particular situation. In this study, the particular situation is student leadership training at three New Zealand secondary schools.

A multiple-case study is useful as it allows findings to be generalised, and it increases the strength of generalisation (Miles \& Huberman, 1984; Yin, 2003). As noted by Berg (2007), better understanding of the phenomenon is gained from a multiple-case study. This allows for theorising to a wide range of schools. It is possible to generalise by developing concepts to explain aspects of what is being studied. These can lead to propositions that can be tested through application or further research (Punch, 2005).

\subsubsection{Distributed Leadership Framework}

The framework used to assess the effectiveness of the training programmes is based on ideas about distributed leadership. For the purposes of my research, this involves an interest in the interactions between leaders, followers and situation (Spillane, 2006). Spillane affirms that ideas around distributed leadership can be applied to students. I am particularly interested in looking at training for leadership practice. As explained by Spillane, "knowing what leaders do is important, knowing how they do it is also essential in understanding the practice of leadership" (Spillane, 2006, p. 5). The focus for distributed leadership is on the interactions rather than the actions of leaders. I am also interested in how student leaders view themselves, and if their training leads them to see themselves as a collective and participating in, what Spillane terms, "co-performance" (p. 59). These ideas informed the data collection strategies and participant selection that are explained in the next section.

\subsection{Research Process}

This section outlines what occurred as the research was conducted.

\subsubsection{Participant Selection}

A multiple-case study was completed by investigating the leadership training programmes in three contrasting types of schools. 
School A Roll approx 1500: Single sex: High decile

School B Roll approx 600: Co-educational: Low decile

School C Roll approx 1200: Co-educational: High decile

See Appendix A for details on the New Zealand secondary school system.

Three schools were chosen based on their accessibility: they needed to be in Lower North Island. I was also keen for schools to have different characteristics to gain a range of school types. Involvement was confirmed in discussion with the principal of the school and the teachers in charge of student leadership, so that the results could be of use to those working in the area of student leadership training.

The first participant in each school was the teacher in charge of student leaders. The bulk of participants in this research were the designated student leaders in each school. The student leaders were defined by the teacher in charge of student leaders. A selection of other students from within the school were chosen to provide a student body perspective in accordance with the view that these students help create leadership practice. All of the data collection was conducted on location in the respective schools.

\subsubsection{Data Collection}

Multiple sources of data were used, which is a strategy that stems from the case study method. This allows for a holistic view of the case through triangulation of data sources. The main method of data collection was through semi-structured interviews. I also used observation and a survey.

Semi-structured interviews allowed me to use the same questions for all sets of interviews to facilitate some comparison. They also allowed for further questions to develop during the interviews in response to each individual's comments. This enabled student leaders to reflect on the effectiveness of the training they receive. As noted by other researchers in the field, semi-structured interviews best allow people to talk freely and raise issues important to them (Shiner, 1999). Kvale's (1996) ideas regarding interviews led me to use prepared questions and to be open to change to follow up on answers and stories. This method of data collection suits a constructivist framework because of the interest in an individual's interpretation (Cohen, et al., 2000), which is conveyed as participants explain their actions. Interviews also suit the case study design as they show participants' thoughts 
and feelings about a situation. I used three phases for the research, as explained in the next sections.

\section{Phase One: Semi-structured interviews}

The first interview in each case study school was with the teacher in charge of student leaders. The questions were both descriptive and evaluative and covered these main areas:

- roles and expectations

- factors impacting on student leadership

- student leaders' impact on the school community

- type and purpose of training

- effectiveness of training

- ideas for future training.

Semi-structured interviews were then completed with student leaders for them to comment on the training they received. Questions ranged from general topics (students were asked to explain what good leadership was) to specific topics about the type of training they had received. The questions were both descriptive and evaluative and covered these main areas:

- good leadership

- personal leadership experiences

- type of training provided

- effectiveness of training

- ideas for future training.

Student leaders were selected in consultation with the teacher in charge in each school. I explained the research to the groups of leaders in each school and asked for volunteers to take part. The aim was to interview 10 student leaders at each school.

Other students in the school were also interviewed to answer the supporting question related to impact on the community. This enabled me to consider distributed leadership by investigating the interaction between leaders and other students. The questions were both descriptive and evaluative and covered these main areas:

- good leadership

- reasons for and impressions of student leaders

- advice for student leaders

- suggestions for future training. 
These students were selected using systematic random sampling (Berg, 2007) from the school roll. This method of sampling was chosen to allow for a random range of opinions from each year level and so that all students in each year level had an equal probability of selection. For each year level, two random numbers were generated between one and the total number of students in that year level. The numbers were then matched to the students at those numbered places on the year level roll. The aim was to interview five students at each school.

See Appendix B for a complete list of interview questions.

Although the plan was to interview a total of 30 student leaders and 15 members of the student body across all three schools, because of logistical and time constraints I was able to interview a total of 23 student leaders and 12 members of the student body. See Appendix $\mathrm{C}$ for details of how many students were interviewed at each school and how they were recruited.

By interviewing teachers, leaders and members of the student body it was possible to see multiple interpretations of the same phenomenon and to examine situations through the eyes of the participants, which, as previously mentioned, is a feature of research in a constructivist framework. I digitally audio-recorded the interviews and transcribed them. I also completed field notes regarding responsiveness and non-verbal communication, both during and following each interview. This made it possible to gain further insight into participants' responses to particular topics.

\section{Phase Two: Observation}

The next step was to observe leadership training sessions at these schools. The plan was to observe (as a non-participant) student leaders attending training in each school to see what training they received and how they responded to the training. Standardisation of observations was to be gained by focusing on three areas over the same period of time in both schools. These included: what training is delivered, in what way and how students respond during the training. This method of data collection also fits a constructivist framework as it allows for an analysis of social episodes and behaviour in context (Cohen, et al., 2000). During the period of data collection only one school held a leadership training session. So I was able to complete only one observation. I have been able to include insights from this training in the results section, but not compare training sessions across schools. 


\section{Phase Three: Survey}

Data were also collected through a survey towards the end of the year from the student leaders who were interviewed in the first phase of the research. I used the Qualtrics survey tool and followed suggestions for online survey design (Iarossi, 2006; Ritter, 2007) to ensure participants were able to complete the survey in fifteen minutes. The survey was distributed by giving student leaders the survey website address.

See Appendix D for the survey. This enabled a comparison of experiences towards the end of the student leaders' year at school to help assess the effectiveness of the training they have received. The questions were based on personal reflection of leadership experiences and evaluation of ideas about training options. There was a $70 \%$ return rate.

\subsubsection{Data Analysis}

The type of data analysis was thematic analysis. This process involved analytical induction as the cases were compared to develop ideas (Miles \& Huberman, 1984). This was an appropriate method to use as I had developed some hypotheses about training from my reading and teaching experience (Patton, 2002). As noted by Berg (2007), this means that the data and analysis are grounded in established theory and also capable of developing new theory. I was able to combine theory on the effectiveness of distributed leadership in schools with the words of participants. Sensitising concepts (which are categories the researcher creates and brings to the data) (Patton, 2002), about leadership were brought to the research process. The data also spoke for itself in the categories that developed from the raw data.

The first step was to code the interview and observational data according to each school to get a sense of the particularities of each case and then by question type to group answers from all schools related to the same question. A set of codes were then created from the literature review and reading of interview transcripts. These codes were based on aspects of leadership and training. I worked through a process of reduction by combining similar key words and topics to come up with 12 codes from both the reading and interviews in order to code the data. See Appendix E for a summary of how the codes were developed.

This process allowed for both etic and emic coding (Creswell, 2008) as I used codes created by the participants and myself to describe their experiences of leadership and 
training. The final codes are what Punch (1998) terms low-inference descriptive codes and higher-inference pattern codes.

By coding the data and comparing similarities and differences, it was possible to find some recurring themes that led to discoveries on effective aspects of leadership training (Punch, 2005). This process was enhanced by frequency analysis of answers to the survey questions.

\subsection{Timeline}

The outline below shows the order of data collection and the stages of analysis and coding.

- Semi-structured Interviews with Teachers and Student Leaders - May-July, 2010

- Observation at School A - May 21, 2010

- Initial Coding of Data - June-July, 2010

- Thematic Codes Developed - August, 2010

- Semi-structured Interviews with Student Body - August, 2010

- $\quad$ Survey Completed - September, 2010

- Continued Coding of Data - September, 2010

- Thematic Codes Confirmed - October, 2010

- Feedback to Participants - November, 2010

\subsection{Credibility and Trustworthiness}

\subsubsection{Validity}

Validity can be defined as the accuracy and credibility of the research (Creswell, 2008). The gap in existing research and the fact that most New Zealand secondary schools have student leaders allows for validity of the research topic. A multiple-case study is a valid method as it delivers quality data through analysis of three schools' experiences of leadership training based on personal and group interactions. It is intended that this study will offer New Zealand-based information to broaden knowledge on student leadership training programmes, including a focus on the experience and reflections of student leaders while they lead. It provides information on what training works when schools aim to prepare students for their leadership role. It allows practitioners to include relevant suggestions in their training programmes. Areas where further research is needed are also identified. 
Validity seeks to ensure that the methodology matches the aims of the research. The three methods of data collection allow for triangulation of data sources, which is a useful aspect of case study research (Yin, 2003) and fits with a constructivist framework. The validity of the research is ensured by triangulation of the data, which gains a range of perspectives to determine what constitutes effective training. Data from the interviews were checked by observations and a survey.

As a multiple-case study, this research also has external validity as the main findings are replicated in three schools. In the first instance, generalisations from these cases can apply to similar types of schools. Any similarities in effective training in all cases may have wider possibilities, allowing for transferability to other types of schools. The findings may be able to be used to improve student leadership training. These improvements stem from the patterns established in this research (Patton, 2002).

Discussions with principals and the teachers in charge of student leadership were held while the findings were drafted to allow them to provide thoughts and feedback on the main conclusions. Feedback sessions were also conducted in each school for student participants. During these sessions, students were given a summary of the case study for their school and a summary of key themes from all schools. We discussed the summaries and students confirmed the accuracy of the findings. Triangulation of data collection strategies combined with continual dialogue with participants provided validity.

\subsubsection{Reliability}

Reliability is determined by whether this study is replicable. In accordance with a constructivist framework, this research is built on the premise that my personal bias will have influenced the study. However, the detailed outline of the research process, including a focus on the triangulation of data sources (teachers, student leaders and members of the student body), allows for others to repeat this case study. The study can be replicated and from the research further comparative studies may be done in other types of schools. It may also lead to research on leadership selection and longitudinal studies on the influence of leadership training in primary or post-secondary school contexts.

This study's main limitation is its small sample of three schools. This condition may mean that examples of best practice may not be able to be replicated in other schools, being 
particularly tailored to the research site. This requires me to clearly specify this study as a multiple-case study of three schools' experiences.

\subsection{Descriptive Data about Cases being Studied}

School A is a large, boys' school with a strong history of academic, sporting and cultural achievements ("School A website," 2010). It has a reputation as both traditional and prestigious. The roll is around 1500 . Year 13 is the largest year group in the school. It has Year 13 leaders who choose to work with teachers in co-curricular areas of the school, a school council and peer support leaders. A head student and three deputies are appointed each year. Year 13 prefects are the main student leaders in the school, and participants for the research were selected from this group.

School B is a co-educational school that has a focus on personal development in a caring, community context ("School B website," 2010). It has a reputation for fostering cultural diversity and individual expression. Its roll has fluctuated from 300 to 700 in the last two decades and school management is currently keen to maintain its roll at around 600. Its main student leaders are head students, members of a senior executive and house leaders.

School C is a co-educational school based on liberal and democratic principles. It also focuses on individual expression and has a commitment to "community not conformity" ("School C website," 2010). It also has an arts and culture focus. The roll is around 1200 students. Its main student leaders are its BOT student reps as well as students elected to year level councils and the school council. It also has peer support leaders and peer mediators.

\subsection{Ethical Considerations}

Ethical considerations include maintaining the rights of participants, following ethical research procedures and ensuring that the research is beneficial (Creswell, 2008). The confidentiality and rights of participants are ensured through ethics approval from Victoria University. School principals were approached initially to allow research to be completed in their schools. Students and teachers gave informed, written consent before participation and were assured of confidentiality. See Appendix F for information and consent forms. Teachers and students commented that their willingness to take part was in part based on their belief that the research would be of personal benefit and of benefit to future student leaders. 
Before each interview began, the aims of the research were outlined along with the participants' rights and the intended use of the information. Participants were given the right to withdraw from the research up until data gathering was complete, and the right to check a transcript of the interview or the observation notes. They were given the opportunity to comment on the research in draft form and have been given pseudonyms. The case study schools received a copy of the final report. 


\section{Chapter 4: Results}

This results section is designed to provide a portrait of each school regarding student leadership training. It includes three case study reports. Each case has a separate section to describe the particular features of leadership and training in each school. This is suggested by Yin (2003) as a reporting option for multiple-case studies. Cross-case analysis of key themes regarding effective leadership training is conducted in the discussion chapter.

In accordance with Spillane's (2006) ideas about distributed leadership, I have focused on the interactions between leaders, other students and their situation. As a result I have not profiled individual participants or groups, but rather combined ideas from all participants as I report on aspects of leadership and training. A suggestion for reporting case studies that advocates blending description of events with analysis is also followed (Cohen, et al., 2000).

Table 4-1 shows how each case study report is organised. It shows six focus topics and the question each topic relates to. A summary is provided at the end of each topic with a list of links to the key research questions.

Table 4-1: Case Study Format

\begin{tabular}{|l|l|}
\hline Topic & Questions \\
\hline Roles & $\begin{array}{l}\text { Supporting Question 1. What is the } \\
\text { nature of training given to student } \\
\text { leaders? }\end{array}$ \\
\hline Current Training & $\begin{array}{l}\text { Key Question: What constitutes } \\
\text { effective leadership training in } \\
\text { New Zealand secondary schools? }\end{array}$ \\
\hline Effectiveness of Training & $\begin{array}{l}\text { Supporting Question 3. How does } \\
\text { training impact on students' } \\
\text { contribution to the school } \\
\text { community? }\end{array}$ \\
\hline Suggestions & $\begin{array}{l}\text { Supporting Question 2. What do } \\
\text { students gain from leadership } \\
\text { training? }\end{array}$ \\
\hline Types of Leadership & \\
\hline
\end{tabular}




\subsection{Case Study One: School A}

The first section of each case study report describes the roles of the student leaders in the case study school to show their leadership experiences. It is necessary to first understand the roles in order to understand the focus of some of the training.

\subsubsection{Roles}

School A's main student leaders are a group of 28 prefects. Students apply to be prefects and are elected to this position at the end of their Year 12 year. The jobs prefects do include monitoring lost property, gate duty and reading at assembly. They also met Year 8 students in 2009 who were identified as potentially having problems transitioning into Year 9 and were buddied with them into 2010. The teacher in charge of student leaders explained that they are also required to attend extra-curricular school events, be more involved in everyday school life and be involved in areas of discipline such as monitoring uniform and crowd control at assemblies.

Peer support leaders are also regarded as student leaders. I did not ask for volunteers from the peer support group but two of the prefects I spoke with are also peer support leaders. Pairs of Year 13 students are allocated eight Year 9 students to support. They are involved in running games and activities during Term One that are designed to build the confidence and social skills of their Year 9 students. Opportunities are also given for them to catch up with their students during Term Two.

At the start of the year, additional leadership opportunities are also offered to all Year 13 students. Teachers are asked if they need a student to take responsibility for a particular area. The list of positions - science technician, maths tutor, sports coach - for example, are offered to the students who then sign up to help. They work for the rest of the year with the teacher in charge of that area.

All of the prefects I interviewed were in other leadership roles in the school situation. This included organising a debating competition, captaining a sports team, leading kapa haka (Māori song and dance performance), organising a student technology conference, running World Vision ${ }^{9}$ in the school, leading the hip hop crew and leading the jazz chorale.

\footnotetext{
${ }^{9}$ World Vision is an international, Christian, humanitarian organisation involved in child sponsorship, community development, aid and relief in third world countries.
} 
Table 4-2 provides a summary of the comments made about the roles by the teacher, leaders and student body. It shows what each type of participant perceives the roles of student leaders to be.

\section{Table 4-2: Leadership Roles at School A}

\begin{tabular}{|c|c|}
\hline \multicolumn{2}{|r|}{ Leadership Roles } \\
\hline Participants & Comments \\
\hline Teacher & $\begin{array}{l}\text { Prefects: } \\
\text { - } \text { serve the school } \\
\text { - } \text { volunteer - take on extra responsibility } \\
\text { - be seen around the school } \\
\text { - be seen doing the right thing } \\
\text { - build school pride in Year } 9 \text { students }\end{array}$ \\
\hline Student Leaders & $\begin{array}{l}\text { Prefects: } \\
\text { - be role models } \\
\text { - } \text { stick to the school's guidelines } \\
\text { - uphold the school's image } \\
\text { - contribute to the school community } \\
\text { - be involved as much as possible }\end{array}$ \\
\hline Student Body & $\begin{array}{l}\text { Head Student and Deputies } \\
\text { - } \text { role models } \\
\text { Form Captains } \\
\text { - administrative tasks } \\
\text { Leaders of Cultural Groups } \\
\text { - } \text { speak in assembly } \\
\text { Peer Support Leaders } \\
\text { - help Year } 9 \text { students feel comfortable } \\
\text { - run activities }\end{array}$ \\
\hline
\end{tabular}

This shows that all participants understand the role of student leader as being involved in school life and being a role model. The teacher is keen for the prefects to see their role as an opportunity to show "servant leadership" (Ian, Teacher, School A). He explained that a good leader is someone who can "see where there's an area of need ... be aware of the less fortunate and see if they can help them out" (Ian, Teacher, School A). Eight of the nine student leaders identified being a role model or an example as part of their leadership role. How students perceive role modelling and how they can be effectively trained in this area will be discussed in Chapter 5. 
Some of the personal qualities student leaders see as being important for a prefect include being friendly, easy to talk to and approachable. One student summarised the expectation from the school for the prefects to "be more appreciative of and caring of other students both in helping teachers with their work when they need help and ... acting as leaders and role models to the other students" (Angus, 17, School A).

Students see the peer support position as involving more individual leadership as they get to know their group of Year 9 students. The leaders' aim is to make the Year 9 students' transition to secondary school a little easier.

Those who hold leadership roles in their extra-curricular activities see themselves as responsible for leading groups, making sure younger students do the right thing, running events, carrying out practical and administrative tasks and caring for the group they run.

Members of the student body see perseverance, confidence and friendliness as important leadership qualities. When I asked participants from the student body what kind of student leaders they had, they mentioned that the school had a head student, deputy head students, team and group captains, form captains, prefects, peer support leaders and sports coaches. The student who mentioned team captains said their role was to be "positive and someone who doesn't get angry easily ... determined who ... keeps going to the end ... encouraging their team on" (Ryan, 12, School A).

One student explained that by speaking in assembly, student leaders could encourage people to join their group and take the stress off teachers. The Year 9 student saw his peer support leader as being like a classmate.

\section{Summary}

Prefects perceive their role to be a combination of being a role model and doing jobs for the school. This helps prefects to consider what leadership is and how leadership happens. For prefects in School A leadership is both about doing and being. In terms of doing leadership, students do tasks and take on particular responsibilities. In terms of being a leader, prefects embody certain beliefs and relate to others as an example. It is a position and an attitude in action. How students form a leadership identity and how schools can train students as they go through this process will be discussed in Chapter 5. In their involvement in everyday school life, the role of the prefect is seen as controlling the level of behaviour and maintaining general standards. Some students see the discipline aspect as 
a policing role. The prefects at School A take part in a wide variety of leadership situations. All participants understand that school leaders combine particular jobs with general responsibility for role modelling and school involvement.

\subsubsection{Current Training}

This section describes the current training that student leaders receive. Having discovered what roles student leaders have, it is possible to see whether the training matches their leadership roles and meets the school's expectations of student leaders. There were four formal training sessions at School A for the senior leaders of 2010. These training sessions were organised by the teacher in charge of student leaders. Table 4-3 summarises what was involved in each training session.

Table 4-3: Current Training at School A

\begin{tabular}{|c|c|c|c|}
\hline \multicolumn{4}{|c|}{ Current Training } \\
\hline When & Who for & Provider & What it involved \\
\hline \multirow[t]{2}{*}{$\begin{array}{l}\text { December } \\
2009 \\
3 \text { Days }\end{array}$} & Prefects & School Staff & $\begin{array}{l}\text { - General information about the role of prefect } \\
\text { - Expectations from principal and teacher in } \\
\text { charge } \\
\text { - Buddying activities with Year } 8 \text { students }\end{array}$ \\
\hline & & Provider 1 & $\begin{array}{l}\text { - } \text { Games } \\
\text { - Team building activities } \\
\text { - Discussion of leadership styles and qualities }\end{array}$ \\
\hline $\begin{array}{l}\text { February } \\
2010 \\
\text { Morning }\end{array}$ & Prefects & Provider 2 & $\begin{array}{l}\text { Students spoken to about: } \\
\text { - theory of leadership } \\
\text { - what makes a good leader } \\
\text { - recognising situations when leadership can } \\
\text { happen and what to do }\end{array}$ \\
\hline $\begin{array}{l}21 \text { May } 2010 \\
\text { Morning }\end{array}$ & Prefects & $\begin{array}{l}\text { Leadership } \\
\text { Consultant }\end{array}$ & $\begin{array}{l}\text { Facilitated discussion: } \\
\text { - encouraged teamwork } \\
\text { - shared ideas for leadership for the rest of the } \\
\text { year }\end{array}$ \\
\hline $\begin{array}{l}\text { December } \\
2009 \\
2 \text { Days }\end{array}$ & $\begin{array}{l}\text { Peer } \\
\text { Support } \\
\text { leaders }\end{array}$ & $\begin{array}{l}\text { Guidance } \\
\text { Counsellor } \\
\text { Teaching staff }\end{array}$ & $\begin{array}{l}\text { Modelling of sessions for leaders to run with Year } \\
9 \text { students in } 2010\end{array}$ \\
\hline
\end{tabular}


The first training session was facilitated by the teacher in charge of student leaders. He spoke to the student leaders along with the principal, the head of Māori and other teaching staff. The activities run by Provider $1^{10}$ had a focus on understanding the importance of team work. They had pictures of famous leaders like Mother Theresa, Hitler, Britney Spears and Richie McCaw for use in the discussion on leadership style and qualities. About 25 Year 8 students who had been identified by teachers from their contributing schools as potentially having difficulties adjusting to life at the college came in to school and they were buddied up with a prefect. They exchanged cell phone numbers, did a treasure hunt, the prefects showed them how to find their way around the school, they played games and had a BBQ together. In the second training session Provider $2^{11}$ came in and ran their session at the school. The third training session was also at the school. The leadership consultant knew a few of the prefects from his role as a Scout leader and was an old boy of the school. He encouraged the student leaders to set some direction for the rest of the year. Teachers from the school ran the peer support games and activities and showed the students how to talk about the issues outlined in the peer support programme.

The interview with the teacher in charge of prefects was designed to give an understanding of what the aims of the training were and what kind of leadership he expected from his students. He explained that there are a number of reasons for having the training sessions. He hopes for prefects

just to know that there are a lot of staff who are going to be supportive of them that they can come and see us if there's a problem and also just to try and get them enthusiastic about the coming year and to come up with some ideas as to where they can get involved (Ian, Teacher, School A).

Other aims from the training sessions for the prefects included to:

- understand different styles of leadership

- identify which leadership model works best for them

- learn public speaking skills

- learn how to run games

\footnotetext{
${ }^{10}$ Provider 1 (name withheld at school's request) is a youth development organisation. It provides youth leadership programmes as part of its youth and family development services.

${ }^{11}$ Provider 2 (name withheld at school's request) is a youth development organisation which focuses on creative arts, leadership and education.
} 
- understand responsibilities associated with the position

- understand implications of always being on show.

In the interviews with the prefects, as well as giving details about the formal training, they also indentified a range of informal training that prepared them for leadership. Most prefects who had leadership roles in sport and extracurricular activities described their training as being "on-the-job" (learning while doing). A student described this as jumping in, growing and filling a role. Some examples of informal training are listed below:

- organising activities while being mentored by a teacher

- acting as the defacto leader of a group prior to Year 13 because of a passion for the activity and having this leadership made official in Year 13

- work experience out of school seen as training for a project management position in the school context

- Year 12 students involved in stage challenge being paired up with Year 13 students who model leadership skills

- $\quad$ sporting experiences teaching students how to see and do what's needed and how to work with teams

How students can learn by doing and in this way be trained for leadership will be discussed in Chapter 5.

The prefects also talked about observing and experiencing the actions and approaches of past prefects and assessing the way they did the job.

I guess watching other people try and then you can see what comes across well or doesn't come across well and who you thinks doing the job and who isn't and sort of use that to figure out what you will be sort of thing and how you want to act (Ethan, 17, School A).

One student described this kind of training as "organic" (Dominic, 17, School A), working your way up, and another as having teachers and older students leading by example. In this way students saw themselves as knowing their situation and community, "you know a lot of people and you get to know the system ... and that makes it a lot easier for you to operate" (Ethan, 17, School A). This was also appreciated by a participant from the student body who saw student leaders as participating a lot in school life and showing a commitment to school pride. 


\section{Summary}

The formal training sessions are designed to introduce, reinforce and review the leadership experience. The first training session was designed to introduce students to their role and to help them consider and experience leadership. Expectations were also established. The session with the Year 8 students provided them with an immediate link to those they would be leading and gave them an authentic context to practise leadership. The second session gave students some of the language of leadership. The third session encouraged both teamwork and reflection.

The examples of informal training are on the job and students see this as preparing them for the relationships and responsibilities of the prefect role. All of the student leaders consider that their prefect training has been ongoing since they started school in Year 9. They mentioned their previous years at school as preparing them for leadership primarily through school groups they were involved in.

Link to supporting question one:

What is the nature of training given to student leaders?

- Formal and informal

- Training sessions planned and overseen by the teacher in charge of student leaders on expectations, leadership styles, the peer support programme, group work and goal setting

- Staff share experiences and ideas

- External providers facilitate learning

\subsubsection{Effectiveness of Training}

This section shows the participants' perspectives on the effectiveness of the current leadership training. As stated in my introduction, my definition of effective training is that it should equip students for leadership and enable students to contribute to the school community. This involves building students' skills and confidence.

When questioned about the effectiveness of the training, students at School A were able to identify a range of topics that they saw as useful and a range of positive results from the training they had received. They were also able to explain what aspects of the training they saw as ineffective. 
Tables 4-4 to 4-6 summarise comments from the prefects about the effectiveness of their training. Each table is followed by further explanation and specific comments from the participants. 
Table 4-4: Training Session 1: School A

\begin{tabular}{|c|}
\hline Training Session One - Introduction \\
\hline All 9 students mentioned it \\
\hline $\begin{array}{l}6 \text { mainly positive } \\
3 \text { mainly negative }\end{array}$ \\
\hline $\begin{array}{l}\text { Negative Comment: } \\
\text { - being taught things they already knew }\end{array}$ \\
\hline $\begin{array}{l}\text { Positive Comments: } \\
\text { - } \quad \text { time spent on expectations and responsibilities } \\
\text { - } \quad \text { introducing the prefect team } \\
\text { - } \quad \text { team building exercises } \\
\text { - } \quad \text { leaning about types of leaders and different ways you can lead } \\
\text { - } \quad \text { personal development training on getting what you want and being } \\
\text { - } \quad \text { bomfortable with yourself } \\
\text { buddy activities with the Year } 8 \text { students }\end{array}$ \\
\hline
\end{tabular}

Students who spoke negatively about the training felt the time was not used effectively as they were being told things about leadership that they had learnt and understood previously:

you spent five years at school learning in yourself out what kind of leader you are and to then be told like put into a box of what the way you lead isn't really the, I think, the right approach (Angus, 17, School A).

Another student also questioned how to apply what they had learnt, implying that the training was not always practical or relevant:

they talked a bit about different ways you can lead and that was quite helpful but then there was a lot of stuff that was I found a little bit iffy ... a bit more difficult to try and bring that back in to what I had to do for the rest of the year (Ethan, 17, School A).

The positive comments centred on appreciation for the content that prepared them for leadership, especially regarding the requirements of the role. Even though some students felt they knew about different ways of leading already, others enjoyed the information they were given on leadership styles. 
It wasn't anything radically new that I hadn't already known before but again it was just putting it out flat this is who you are now and this is what you have to do, these are your responsibilities (James, 17, School A).

Three students also appreciated the experience of working with the Year 8 students as it was a practical example of how to lead and how to be a role model.

I found that particularly helpful and we played games with them ... by having us get to know some of the perhaps weaker links in the school ... was a really cool thing cos it meant that we could then ... look out for them which is something I find important in a school environment with leadership is someone who's always ... looking out for everyone ... and caring about everyone (Dominic, 17, School A).

The teacher also saw this as having a positive impact on the parents of these students, putting them more at ease about their son's transition to high school. The expectation for them to be role models was effectively communicated by management during this training session.

Table 4-5: Training Session 2: School A

\begin{tabular}{|c|}
\hline Training Session Two - Provider 2 \\
\hline 7 students mentioned it \\
\hline $\begin{array}{l}4 \text { mainly positive } \\
3 \text { mainly negative }\end{array}$ \\
\hline $\begin{array}{l}\text { Negative Comment: } \\
\text { - } \quad \text { style of delivery boring } \\
\text { - } \quad \text { lost interest because of presentation style - being talked at }\end{array}$ \\
\hline $\begin{array}{l}\text { Positive Comment: } \\
\text { - } \quad \text { confidence gained through reporting group findings to the team } \\
\text { - } \quad \text { reinforced ideas about leadership they had already developed }\end{array}$ \\
\hline
\end{tabular}

The training by Provider 2 included the presentation of information and group activities. Regarding the training on styles of leadership, one student saw this as helpful as it was reinforcement of information they had learnt previously and were practising. Another saw it as being out of date:

it was just what it means to be leader and discussing styles of leadership and that kind of thing and are you a lion or an otter or those things and that wasn't very appropriate for the age group ... I don't think it's really appropriate for any age 
group any more I think ... as a society we've moved past that a bit (Riley, 17, School A).

Two students had negative comments about the style of delivery, "they were quite long sessions and a lot of people phased out a little bit" (Ethan, 17, School A).

Table 4-6: Training Session 3: School A

\begin{tabular}{|c|}
\hline Training Session Three - Consultant \\
\hline $\begin{array}{l}3 \text { interviewed prior to this training } \\
6 \text { interviewed after this training }\end{array}$ \\
\hline All 6 positive \\
\hline $\begin{array}{l}\text { Positive Comments: } \\
\text { - consultant facilitated discussion skilfully } \\
\text { - } \quad \text { consultant allowed them to work as a group } \\
\text { - } \quad \text { prefects able to discover the mindset of the group } \\
\text { - } \quad \text { prefects able to stand back, reassess, take stock of the leadership } \\
\text { - } \quad \text { procesience } \\
\text { pross enabled them to recognise weakness and set goals }\end{array}$ \\
\hline
\end{tabular}

The students perceived this to be the most effective of the three sessions.

I found [it] particularly effective because it ... enforced what our roles were .. and it gave us a better idea of ... if we zoom ... it's better to just ... stand back and go so this is what I need to do and then you can zoom back in and ... it's much easier to do what you're doing because you have that bigger idea of what's going on (Dominic, 17, School A).

The consultant was seen to bring them together as a group by facilitating discussion and encouraging group work.

I think it was effective in terms of it brought us together as a team and it kind of it put us in a trough really to recognise our weakness but then pulled us out by setting some goals ... recognising your weaknesses is the first point to fixing them (Riley, 17, School A).

At the conclusion of the training, students had created a plan of action and resolved to start meeting together more regularly. One student who was critical of the previous two training sessions described the presenter of the third training as effective because he "engaged us, provoked us and led us to a conclusion" (Riley, 17, School A). 
The two students who had completed the peer support training appreciated learning how to run the programme:

we learnt from them ... how to talk about bullying without making it seem like you're talking about bullying ... trying to get them to open up things like that and as well as that ... little games that we can play to get the ball rolling and ... loosen them up a bit (James, 17, School A).

The teachers were seen as effective peer support trainers because they are from the school, know the students and enable them to discuss the topics from the peer support programme, "they knew their audience really well and that made it really easy [to] ... know what to do and easier to work with them" (Ethan, 17, School A).

\section{Summary}

Student leaders have a range of opinions about the formal training sessions. They feel that an engaging presentation is important. Students also appreciate being actively involved in discussion and activities. This includes setting the direction of a discussion and learning games that they would be able to use when in leadership. They place value on group work that enables them to get to know members of their leadership team. They enjoy practising leadership, especially in situations with members of the student body. Opportunities to work together during training sessions are also seen as effective. If students can see an immediate and practical application for the training, they consider it effective.

This type of training also matches effectiveness as defined in my introduction as equipping students for leadership and enabling students to contribute to the school community. They are equipped through the discussion and sharing of ideas. They are enabled through experience. As they work together, they implement activities that make a positive contribution to the school community by providing opportunities for students to participate in school life. I suspect that this has follow on benefits for staff, parents and caregivers.

\subsubsection{Suggestions}

Building on what is already seen as beneficial, in this section participants share their ideas about what would be effective for future training of student leaders. Table 4-7 summarises the suggestions from the participants. 
Table 4-7: Suggestions for Training School A

\begin{tabular}{|c|c|}
\hline \multicolumn{2}{|r|}{ Suggestions for Training } \\
\hline Participants & Ideas \\
\hline Teacher & $\begin{array}{ll}\text { - } & \text { combine theory and practical } \\
\text { - } & \text { providers adapt session to match type of group } \\
\text { - } & \text { allow hands-on experience } \\
\text { - } & \text { build up team spirit }\end{array}$ \\
\hline Student Leaders & $\begin{array}{l}\text { - } \quad \text { a few more sessions would be good } \\
\text { - } \quad \text { overnight camp - bonding experience } \\
\text { - } \quad \text { needs to be practical } \\
\text { - } \quad \text { Year } 12 \text { students help Year } 13 \text { students } \\
\text { - } \quad \text { head prefects set goals with senior management } \\
\text { team and then discuss them with prefect team } \\
\text { - } \quad \text { previous prefects help and mentor current prefects } \\
\text { leadership experiences }\end{array}$ \\
\hline Student Body & $\begin{array}{l}\text { - } \quad \text { prepare leaders for interactions with others } \\
\text { learn how to get along with others and facilitate } \\
\text { everyone's needs } \\
\text { use past prefects to relay information and discuss } \\
\text { what was important for the role }\end{array}$ \\
\hline
\end{tabular}

These suggestions include a range of ideas for their school and others to implement. Regarding the facilitators of the training sessions, the teacher suggested they need to be responsive to the situation. "The skilled facilitators at the beginning of the year might be able to judge what type of group they have and change en route" (Ian, Teacher, School A). A key suggestion from students was that training needs to be practical and applicable:

I just think as specific and hands on in your examples you can be the better because ... I think if you get 25 people in a room and you just talk about ... general ideas for 3 hours ... you've zoned out for two and half of those and so ... I really think that you need to engage them but ... engage them with ... practical things and specific things which they should do in certain situations ... I would ... suggest as practical as you can be and ... as specific and try and relate it as much back ... to what's gonna happen as possible (Ethan, 17. School A).

I guess for me more practical examples cos ... it's all good to say what a leader is, what a leader needs to do but you need to ... bring it into context cos if you don't have it in context it's ... not really applicable (Kahu, 17. School A). 
If students are put in situations to lead they can work with the group and develop an individual response to their leadership role. One student suggested drip-feeding of leadership training so that Year 12 students could help Year 13 students and students could be given "restrained independence" (Angus, 17, School A) at the start of their leadership year. Students suggested using members of the school community to provide student leadership training.

A member of the student body thought it was important that schools "let them know what they can and can 't do like the rules around what they're doing" (Mason, 16, School A). Another student thought that people should "learn to be out there and ... even if you look like an idiot it's better than hiding in your own little shell" (Eli, 15, School A). Past prefects could "give them an understanding of what's gonna happen" (Mason, 16, School A). These results show the student body thought training should focus on the context and involve learning people skills as well as ways of leading.

\section{Summary}

These suggestions show students would like leaders to be aware of the situation they are leading in. The suggestions also focus on the usefulness of experiencing leadership in preparation for senior leadership roles. Students see their own environment as providing the necessary people and contexts for effective leadership training.

A number of students expressed the belief that they learn best "on-the-job" and that the best training was to put students in situations to lead. This became a common theme as I interviewed student leaders in all schools. It will be considered further in Chapter 5.

\section{Link to key question.}

\section{What constitutes effective leadership training in New Zealand Secondary Schools?}

- Discussion and activities

- Group work

- On site at the school

- Practising leadership in authentic contexts

- Content with links to the leadership situation 


\subsubsection{Community Connections}

This section analyses the connections between student leaders and the school community to see how student leaders operate in their situation and whether the current training produces the desired results.

In accordance with ideas about distributed leadership, it is important to assess the interactions that student leaders have with their community. In this section it is also possible to consider the impact of leadership training on the school body. Table 4-8 summarises how the prefects view groups in the school community.

Table 4-8: Community Connections - Prefects' Comments - School A

\begin{tabular}{|c|c|}
\hline \multicolumn{2}{|r|}{ Community Connections } \\
\hline $\begin{array}{l}\text { Prefects' perception of } \\
\text { connections }\end{array}$ & Comment \\
\hline with staff & $\begin{array}{l}\text { Staff } \\
\text { - } \quad \text { encourage individuals in leadership } \\
\text { - } \text { give students responsibility } \\
\text { - } \quad \text { mentor students when running events in their co- } \\
\text { curricular activities } \\
\text { - helped by student leaders }\end{array}$ \\
\hline with student body & $\begin{array}{l}\text { Leaders } \\
\text { - link staff and students } \\
\text { - help integrate new students into school } \\
\text { - } \quad \text { can feel like police when giving detentions }\end{array}$ \\
\hline with peers & $\begin{array}{l}\text { - leaders need to balance leadership and friendship } \\
\text { - friends can help you be a good leader }\end{array}$ \\
\hline with others & $\begin{array}{l}\text { - ideas about teamwork are gained from sport } \\
\text { - individuals are mentored by older students }\end{array}$ \\
\hline as a leadership team & $\begin{array}{l}\text { - } \quad \text { want to be unified } \\
\text { damaged by individuals within the team not meeting } \\
\text { expectations }\end{array}$ \\
\hline
\end{tabular}

Table 4-9 summarises how the student body views the student leaders. 
Table 4-9: Community Connections - Student Body's Comments - School A

\begin{tabular}{|c|c|}
\hline \multicolumn{2}{|r|}{ Community Connections } \\
\hline Student body's perception of & Comment \\
\hline student leaders & $\begin{array}{l}\text { - } \quad \text { bridge between staff and students } \\
\text { - } \text { helpful and useful } \\
\text { - } \quad \text { contribute a lot to the school } \\
\text { - } \quad \text { represent the school } \\
\text { - help teachers run the school } \\
\text { - have a positive impact on school activities } \\
\text { allow certain teams to exist }\end{array}$ \\
\hline
\end{tabular}

In School A, the teacher in charge of student leaders holds the belief that the prefects are essential in building school spirit. Other staff also have input into leadership development. Students feel a range of expectations from staff. These include being caring of other students, helping teachers with their work, acting as leaders and being role models. One student explained that because of his leadership role, "teachers expect a little bit more of you ... just the way you act and the effort you put in" (Angus, 17, School A).

There were a range of ideas from the student body about prefects' actions. One junior student was unaware of what they do and had only noticed them sitting in assembly and wearing an identifying badge. On the other hand, a senior student thought that prefects are likeable and contribute a lot to the school.

Only one of the participants from the student body mentioned the prefects as being role models. Even so, he thought they were too distant to be role models for him personally. When prompted for comments in this area, one of the student body suggested there were two types of role models. The first was the prefect who was popular with the teachers and a role model or good example for people in what he termed the "outer world" (Eli, 15, School A). The second was the prefect who was popular with the student body and a role model for them through his achievements.

There were a range of comments from the student body about how the school benefited from having effective student leaders. One student said they "help keep the structure ... it's like a second level of control" (Mason, 16, School A), and another, "otherwise it would just be kind of anarchy amongst the students" (Eli, 15, School A). Three participants from the student body said that student leadership has a positive impact on school activities. Events promoted by student leaders are seen to gain greater engagement from the student body. 
The school was seen by another student to look better because students were getting involved.

Prefects were interested in how the student body perceived them. As Year 9 students they had admired the prefects and they want the current Year 9 students to look at them in the same way. Consideration about whether or not they were seen as "awesome" was also encouraged at the leadership training session. There was a lot of reflection on how to relate to those who looked to them for leadership. These views included knowing who you are leading and ranged from being empathetic and selfless to stamping your authority on the group. One student thought you should always be able and available to talk to anyone and another suggested it was important to "listen I find is quite good and ... being able to relate to others well as well and being able to serve others as a leader" (Logan, 17, School A). One student mentioned that they are expected to be "more ... appreciative and caring of other students" (Angus, 17, School A). On the other hand, there is also a sense of some of the prefects feeling like police in their interactions with some students when giving detentions and monitoring behaviour.

The student body also identifies problem areas regarding this role. One student observed that some prefects seemed to find it hard to adapt, whereas others made the most of this duty. This seems to highlight some inconsistency in approach. Two participants from the student body observed a sense of conflict in some prefects. One explained:

the policing is I think looked down on like if you're a cool prefect you turn a blind eye to the stuff that goes on but I think there's a limit like if there's a fight going on you'd probably expect the prefect to stop it (Eli, 15, School A).

Another student confirmed this and thought that because prefects are friends with the students, prefects might let them get away with minor offences, however, if someone was doing something obviously wrong prefects would pull them up on it.

The prefects described their peers as being bemused when they changed from being normal to slightly different on being chosen as a prefect. One student mentioned that he had not expected his own year group to look at him as a leader. They were forced to change some of their ways of relating to their peers as a result of being student leaders. One student explained the need to balance being both a leader and a mate: 
If you're leader of a group you gotta have your times when you're like the leader then you've got to have times when ... you're a mate if you're a friend so you've gotta have friends and you have to like chose when you're a leader. (Connor, 17, School A).

Another student commented during the third training session that friendships continue past school and a goal should be to protect friendships. So there was a sense of some students feeling torn between the expectations of the school and those of their friends.

The teacher's aim is for the prefects to learn to rely on each other. The leadership training session I observed ended with students confirming the idea that a successful team makes its own opportunities and has initiative. This is evidence that the training led them to follow distributed leadership ideas about the importance of the group and leading as a collective.

\section{Summary}

Prefects interact with staff and students in their capacity as leaders on a daily basis. Student leaders are seen as liaisons between staff and students. Prefects have a strong desire to be admired by junior students. They want to inspire others so that others aspire to be leaders like them in the future. Because they wear an identifying badge, they are recognised around the school and expected to act in certain ways. This may include helping staff and maintaining standards in the student body. This provides opportunities for leadership as they run groups and act as role models. Prefects can experience a conflict of interest when leading friends and enforcing rules. This indicates they are developing an understanding of the impact of leadership expectations on existing relationships. Those in the student body seem to look up to leaders who get on with others, support the school and help the school community. Staff and students generally appreciate the leadership of the prefect team. Prefects are seen as usefully contributing to school life and spirit.

\section{Link to supporting question.}

How does training impact on students' contribution to the school community?

- Leaders act as role models for the student body

- Leaders serve and support the school community

\subsubsection{Types of Leadership}

This section summarises and comments on the leadership styles of student leaders. 
It seems that, as a result of training and experience, students develop ideas about forms of leadership. These ideas are useful for the design of training programmes as it is possible to draw conclusions about the type of leadership that resonates with students. It seems likely that students will feel more inclined to learn and be more capable of practising a style of leadership that they feel comfortable with. Prefects see leadership as happening in a variety of ways; from the front, from behind and from the middle of a group. The greatest range of comments occurred when students were talking about leading from the middle, as part of a group. This shows that their leadership adheres to principles of distributed leadership where understanding the group context is important for successful leadership. Table 4-10 shows three types of leadership and what the participants perceive to be involved in leading in each way.

Table 4-10: Types of Leadership at School A

\begin{tabular}{|l|l|l|}
\hline \multicolumn{2}{|c|}{ Types of Leadership } \\
\hline Type of leadership & Involves \\
\hline Leading from the front & $\bullet$ & speaking to assembly \\
& $\bullet$ & sparking school spirit \\
& $\bullet$ & starting new traditions \\
& $\bullet$ & taking charge to solve problems \\
& $\bullet$ & teaching \\
\hline Leading from behind & $\bullet$ & making things happen \\
& $\bullet$ & serving others \\
& $\bullet$ & keeping things running \\
\hline $\begin{array}{l}\text { Leading from the } \\
\text { middle }\end{array}$ & $\bullet$ & getting everyone to help \\
& $\bullet$ & setting an example \\
& $\bullet$ & working with and alongside people \\
& $\bullet$ & representing a group \\
& $\bullet$ & being part of a team \\
& $\bullet$ & role modelling \\
\hline
\end{tabular}

One student had some insights into the differences between leading males as opposed to females: with males you could tell them to "shut up and get on with it" (Riley, 17. School A), which is more of a direct, upfront approach. The kapa haka leader recognised his leadership experience as leading from the front as he has to stand up and lead his group. There are some contexts where the heroic leader paradigm is dominant and a single visionary leader is seen as appropriate.

In contrast to the visible role of leading from the front, some students see leadership as leading from behind, “it's the invisible things that you don't see ... prefects actually 
organise a lot of things that are behind ... you don't see what they're doing but you see the event that they put on" (James, 17, School A). They value the ability to listen to, and then serve, others.

Many students see themselves as part of a group and leading from the middle of the group. For example, one student explained that this might involve "seeing what needs to be done and then doing it" (Christopher, 17, School A). A number of students consider it their place to contribute and help out. This might involve getting everyone to help. For a member of the student body, one of the ways he saw leadership happening was when students became an ambassador for their team. For two students this occurred because of the passion they had for an extracurricular activity, and for another because he took on a leadership role in a group organising an event. One student identified leading from the middle as tied to role modelling and mentoring as he makes sure the younger members of his sports code are doing the right thing. This aspect was also noticed by one of the student body who saw the purpose of student leaders as providing students with someone to look up to and "if they don't want to ask a teacher they can ask someone of their own age or a bit older than them" (Lucas, 16, School A). The same student that observed males can be instructed noted that, when working with girls, it's better to work with them on the project in a collaborative, consultative way. One student described a good leader as "someone who can provide the opportunity for people around them to grow" (Dominic, 17, School A), which implies close contact with the group. Leading from the middle could make this occur.

Two observations about the pressures of leading from the middle of a group were to do with peer and staff expectations. One student commented that, in his co-curricular activity, staff expected more effort from him because he was a student leader of the school. As previously mentioned, a general consensus in the third prefect training session was that it is difficult to tell students what to do in their peer group of other Year 13 students. Leading from the middle is difficult in this context. Even with these problem areas, leading from the middle is the type of leadership that most students use and feel most comfortable with.

\section{Summary}

Students identify three main types of leadership and recognise situations where leading from the front, leading from behind and leading from the middle are necessary and effective. They perceive leading from the front as necessary when giving direction. 
Leading from behind is working behind the scenes. Leading from the middle is being part of a group, contributing and being a role model. They most enjoy being part of a group and leading from the middle of it when necessary.

\section{Link to supporting question.}

What do students gain from leadership training?

- Ideas about leadership styles

- Experience of leading as part of a team

- An understanding of the expectations associated with the role

\section{Case Study One: School A: Overall Summary}

School A has a range of leadership opportunities, especially for senior students. The prefects are the main group of leaders. Their leadership mainly consists of role modelling and serving the school. They are trained informally through their school experiences. Their formal training consists of three training sessions run at the school. The participants perceive the most effective training to be applicable and based around active participation. Experience and training leads students to form a sense of identity as a leader and enjoy leading from the middle of a group or as part of a team.

\subsection{Case Study Two: School B}

\subsubsection{Roles}

The student leaders at School B have three main roles. There are five head students, four house captains (each with three deputies) and ten members of the student executive ${ }^{12}$. The head students represent the student body. The student executive run school student-based activities. House leaders lead their house in the activities for the house competition. They attend meetings with other house leaders and a staff member to plan for house events. They run house meetings, which involves speaking to a large group to motivate and encourage participation. During the house meetings, the leaders strategise for the next event, which includes planning costumes and practising chants. At the actual event, they tell their house where to go and they lead chants. Students also take on leadership in co-curricular activities.

\footnotetext{
${ }^{12}$ Referred to by participants as "the exec" or "student exec". These are the terms used in the remainder of this thesis.
} 
Table 4-11 provides a summary of the comments made about the roles by the teacher, leaders and student body. It shows what each type of participant perceives the roles of student leaders to be.

\section{Table 4-11: Leadership Roles at School B}

\begin{tabular}{|c|c|}
\hline \multicolumn{2}{|c|}{ Leadership Roles } \\
\hline Participants & Comments \\
\hline Teacher & $\begin{array}{l}\text { Head students and sports captain } \\
\text { - } \quad \text { talk in assembly } \\
\text { - } \text { run end of year assembly } \\
\text { Leaders } \\
\text { - model good behaviour } \\
\text { - } \quad \text { act as role models }\end{array}$ \\
\hline Student Leaders & $\begin{array}{l}\text { Head students } \\
\text { - } \quad \text { be a good role model } \\
\text { - } \text { inspire others } \\
\text { Sports captain } \\
\text { - } \quad \text { get people to participate } \\
\text { - } \quad \text { report results in assemblies } \\
\text { House leaders } \\
\text { - } \quad \text { aim to get house members to participate in house } \\
\text { - } \quad \text { run house meetings } \\
\text { Student executive } \\
\text { - fundraising } \\
\text { - } \quad \text { set up programmes } \\
\text { - } \text { run school-wide events }\end{array}$ \\
\hline Student Body & $\begin{array}{l}\text { Head students } \\
\text { - } \quad \text { role models } \\
\text { - } \text { attend formal events } \\
\text { - } \text { speak in assembly } \\
\text { - give messages from students to principal } \\
\text { BOT rep } \\
\text { - pass on student concerns to staff } \\
\text { - } \quad \text { represent the students on the board } \\
\text { House leaders } \\
\text { - run meetings } \\
\text { - run house events } \\
\text { Student executive } \\
\text { - } \quad \text { organise things }\end{array}$ \\
\hline
\end{tabular}


The teacher explained that there is nothing written down to define what the student leaders do but

I believe leaders need to be really visible in the school and when they're visible to be doing the right thing and so the other kids can learn from them and aspire to be like that to help mould a culture of a school (Sarah, Teacher, School B).

She commented on the fact that they have been "chucked in ... and done little things" (Sarah, Teacher, School B) for the school. She considered part of their role was to present themselves well in their uniform and in the way they behaved around the school.

One head student commented on the desire to make sure students get the best learning environment. She explained this as making sure people feel comfortable in order to get involved. There was a sense that these leaders do not want to be seen as authority figures, telling students what to do. Instead they were keen to be "the cool cats that everyone can listen to and ... looks up to" (Luke, 17, School B). One student was keen to get out there and be visible as an exec member.

All the student body participants at School B think it is important for student leaders to be able to listen to others. They consider helpfulness, the ability to motivate others, determination, being trustworthy and non-judgemental as good leadership characteristics. When asked what kind of student leaders their school had, they mentioned, head boy and girl, year level representatives on the school council, student executive members, house leaders, peer mediators, sports captains and tutors. The Year 13 participant from the student body was the only person across all three schools that mentioned the Year 13 cohort as being leaders. The Year 11 participant from the student body was the only person across all three schools to mention the board of trustees' representative as a student leader and she based many of her comments around this leader's role.

When commenting on the BOT student rep she said, "I think they represent the school very well on the board of trustees ... most of our ideas that we voice to them they pass it on and we get most of what we would like" (Tia, 15, School B). Although Year 13 were mentioned as leaders by one student, the same student recognised that they did not really have an official role but younger students did look up to them. The sports captain was seen by one student as someone who you could ask questions of and who would pass things on to a sports coach if players did not feel comfortable doing it themselves. 


\section{Summary}

The head students see themselves as the face for the students, which includes relating to students and advocating for students with staff. This perception is confirmed by members of the student body who see student leaders as representing the student voice on the board, to the principal and to the staff. There is a sense of house leaders being both part of and slightly set above the other students in this leadership role. Being voted into leadership by the group they lead allows them to have student body support from the start of their tenure. The students from the student executive also see themselves as representing the school. With the lack of job descriptions or specific tasks for some student leaders, the leadership role is defined and created by the individuals in these positions. The student body mainly appreciates the work of the student leaders, seeing them as beneficial for the school. They are seen as evidence that students have a say in the running of the school.

\subsubsection{Current Training}

The school does not run its own leadership training sessions or courses. Five of the student leaders I interviewed had been sent on externally-run courses by the school. Table 4-12 summarises what was involved in each training session.

Table 4-12: Current Training at School B

\begin{tabular}{|c|c|c|c|}
\hline \multicolumn{4}{|c|}{ Current Training } \\
\hline When & Who for & Provider & What it involved \\
\hline $\begin{array}{l}\text { January } \\
2010\end{array}$ & Volunteers & World Vision & $\begin{array}{l}40 \text { Hour Famine } \\
\text { - } 40 \text { Hour Famine weekend conference } \\
\text { - information and ideas on how to run the } \\
\text { Famine in your school }\end{array}$ \\
\hline $\begin{array}{l}\text { Term } 3 \\
2009 \\
8 \text { weeks } \\
3 \text { days-a- } \\
\text { week } \\
6-9 \text { am }\end{array}$ & $\begin{array}{l}\text { Selected } \\
\text { Students }\end{array}$ & $\begin{array}{l}\text { Police } \\
\text { Community } \\
\text { Engagement } \\
\text { Team and } \\
\text { School B }\end{array}$ & $\begin{array}{l}\text { CACTUS } \\
\text { Combined Adolescent Challenge Truancy Unit } \\
\text { and Support } \\
\text { - encouraging self responsibility } \\
\text { - gym work out } \\
\text { - breakfast }\end{array}$ \\
\hline $\begin{array}{l}\text { Date } \\
\text { unknown }\end{array}$ & $\begin{array}{l}\text { Self-selected } \\
\text { students }\end{array}$ & $\begin{array}{l}\text { New Zealand } \\
\text { Army }\end{array}$ & $\begin{array}{l}\text { ACE } \\
\text { Army Careers Education } \\
\text { - Army careers presentations and displays } \\
\text { - week living in a military camp } \\
\text { - } \quad \text { physical training }\end{array}$ \\
\hline $\begin{array}{l}\text { Date } \\
\text { unknown }\end{array}$ & $\begin{array}{l}\text { School- } \\
\text { nominated } \\
\text { students }\end{array}$ & Rotary & $\begin{array}{l}\text { Leadership Day } \\
\text { - } \quad \text { Public speaking training } \\
\text { - } \quad \text { Ideas on how to lead } \\
\end{array}$ \\
\hline $\begin{array}{l}\text { April } \\
2010\end{array}$ & $\begin{array}{l}\text { School- } \\
\text { nominated } \\
\text { students }\end{array}$ & $\begin{array}{l}\text { Halogen } \\
\text { Foundation }\end{array}$ & $\begin{array}{l}\text { Halogen Leadership Day } \\
\text { - motivational speakers }\end{array}$ \\
\hline
\end{tabular}


One student had been a part of CACTUS, run by School B and the local Police community engagement team for 25 year 9-13 students - an intensive programme encouraging them to take self-responsibility (Woolnough, 2008). It targeted junior students with behavioural problems. The same student had also been on an ACE course as well as a Rotary (international service club) leadership day.

Five students had been to a Halogen Leadership Day. These leadership days are run by the Halogen Foundation, which is a non-profit organisation that operates in New Zealand, Australia and Singapore. Their aim is "to inspire and influence a generation of young people to lead themselves and others well" ("Halogen Foundation," 2010). They run leadership days once a year for primary, intermediate and secondary students in main centres around New Zealand. The aim of these days is "to inspire, empower and motivate students to be effective leaders in their school and community" (Sarah van't Hof, personal communication, 23 August 2010).

When asked what kind of training student leaders are given, the form teacher of the senior student leaders explained that they do not have a formal programme, but students are sent to courses outside the school. They can self-select to attend things like the On the Edge youth forum. On the Edge is a youth trust that promotes leadership. Established in 2003, it runs forums and conferences for youth by youth ("On the Edge - about us," 2010). The form teacher provides them with the opportunities that the school is invited to take part in.

Student leaders interviewed in School B initially explained that they had not received any training. However, on reflection, they all came up with a range of things that they saw as training them for what they are doing. Some training came from personal experience and initiative. One of the head students said that his training came from internal feedback he'd given himself. He was led to "just do what I think is right" (Luke, 17, School B).

Students who had been on the senior exec as Year 11 and 12 students had learnt from older students who were also on the exec with them in previous years. House leaders also used previous house leaders as an example to follow. From being part of the house and led by them they knew how to stand up in front of the house, how to present themselves and how to talk to other students. One house leader also saw the meetings he had with other house leaders and a teacher as an opportunity to learn from each other. At the Halogen 
Leadership Day, students listened to motivational speakers talk about different types of leadership and the right things to do.

The training at School B derives from the supportive relationship students have with their teachers. They are encouraged in their leadership and directed to external courses. These external courses provide both experience of, and ideas about, leadership.

Link to supporting question one:

What is the nature of training given to student leaders?

- External training courses

- Informal feedback - personal and from staff

- Planning meetings

- Motivational speakers

\subsubsection{Effectiveness}

The students who had been on courses run by external providers identified a number of topics that they found helpful. The student who had attended the Rotary leadership day appreciated suggestions about using your voice when speaking to a large group at that training session but found their ideas about leadership unconvincing. CACTUS was viewed as useful because students learnt to give clear instructions and to lead by example. ACE also drew positive comments as it developed discipline and fitness, focused on team work and taught the attendee that you can not control everything all the time. The student who had been trained by World Vision on running the $40-$ Hour Famine ${ }^{13}$ enjoyed hearing facts and stories from the speakers' personal experiences and felt the training got her involved in leading the Famine. The students who attended the Halogen Leadership Day described it as motivational. They spoke positively about being given a range of opinions and interesting information about personality types and how they link to leadership. They were reminded to be assertive and found it useful to be encouraged to set goals and get out and talk to others.

\footnotetext{
${ }^{13}$ An annual event run by World Vision and New Zealand schools where participants are sponsored to abstain from something for 40 hours with the money going to World Vision projects.
} 
The student body believe that their leaders interact well with other students. They feel they are listened to and well represented. The focus from the leadership day and the school's expectation on getting out and about was fulfilled. One student noticed:

they interact with [students] during lunchtimes there's PE stuff going on in the gym and they interact with the kids there and ... some people play soccer or like touch rugby on the fields during lunchtime and they help and they play with them (Natalia, 16, School B).

\section{Summary}

Although students do not receive formal training in the school context, they feel confident in their leadership position. Their experiences on external courses equip them for leadership by motivating them and encouraging them to consider how to interact effectively with the student body. This boost in confidence enables them to contribute to the school community by speaking to students in assemblies and meetings, as well as when running events.

\subsubsection{Suggestions}

Table 4-13 summarises suggestions from the participants for future training.

\section{Table 4-13: Suggestions for Training: School B}

\begin{tabular}{|c|c|}
\hline \multicolumn{2}{|r|}{ Suggestions for Training } \\
\hline Participants & Ideas \\
\hline Teacher & - give students areas of responsibility \\
\hline $\begin{array}{l}\text { Student } \\
\text { Leaders }\end{array}$ & $\begin{array}{l}\text { - } \quad \text { send student leaders on courses } \\
\text { - give students situations to do leadership } \\
\text { - } \quad \text { give students areas of responsibility } \\
\text { - link current leaders to younger students } \\
\text { - } \quad \text { start leadership earlier }\end{array}$ \\
\hline Student Body & $\begin{array}{l}\text { - give lots of opportunities for leadership } \\
\text { - } \quad \text { allow BOT student rep position to be open to everyone } \\
\text { - } \quad \text { team building exercises } \\
\text { - course on how to relate to others }\end{array}$ \\
\hline
\end{tabular}

Regarding how to do future training, one of the head students thought student leaders should "get out with a group of people you don't know to make new friends and to experience it" (Luke, 17, School A). Regarding being given areas of responsibility, one student thought students could be made cultural captain, charity captain or put in charge of leading assemblies, and they could be responsible for that area for the whole year. This 
idea was supported by the form teacher of the student leaders who thought this could be useful for future training. Two students thought training could be effective when given to younger students who were interested or elected as leaders. This idea was echoed by one of the student body. Other suggestions came from a focus on ways of leading. "Something that allows the leaders to... go through different things to help to understand ... the difference between being too strict, being too close to students and too close to the staff and stuff' (Natalia, 16, School B).

\section{Summary}

Like School A, students' suggestions for future training also focused on practical ideas. There was support for students being given specific areas of responsibility although this may be a structural rather than a training-based suggestion. Most suggestions seem to come from the premise that the best training is "on-the-job".

\section{Link to key question.}

\section{What constitutes effective leadership training in New Zealand Secondary Schools?}

- Reminders of how to get involved in school life

- Speakers sharing personal experience

- Ideas about speaking to large groups

- Practising leadership in authentic contexts

- "On-the-job" training

- Starting training early through mentoring

\subsubsection{Community Connections}

The primary link to staff was through the form teacher of the leaders. She is responsible for their pastoral care, encouraging them in their roles and keeping them on track. She also runs senior exec meetings during form time when possible. She considers that leaders need a "strong will to withstand what's cool" (Sarah, Teacher, School A). She encouraged student leaders to be a good example for others around the school by doing the right thing. One student saw his role as being a link between staff and students so students' views were understood and concerns were shared.

School A and School B were similar in that the student leaders were grouped together in the same form class. However, unlike School A, School B does not have the same sense of the student leaders being a team. Perhaps this was because students did not have the same 
title and function. Instead, they were grouped into the three different sub-groups which entailed different roles and expectations. There was a strong sense from the student leaders that their purpose is being the face for the student body, their guides and their representatives. This purpose was noticed and appreciated by the student body.

All the student body participants talked about student leaders representing the students by being their voice, bringing their perspective and giving their opinions to staff and management. One student considered the purpose of student leaders was "to show the students that we can voice our opinions and that we do have a say in this school" (Tia, 15, School B).

Regarding their interactions with the student body, there was a sense from student leaders of wanting to be on their level, as a peer rather than someone of higher status. Two students from the student body saw student leadership as having a positive impact on the school and one thought that their impact was not always seen and might be more behind the scenes.

Student leaders talked about all kinds of students; past, present and future. They thought they would benefit from the insight of previous student leaders and there was also a common interest in younger students. Two students were keen to link current leaders to future leaders to give the future leaders help and guidance as they developed into their role.

\section{Summary}

The leaders have a strong focus on the student body. Their desire to represent and advocate for the students is valued by the student body. The interactions between the teachers and student leaders are based on informal guidance and encouragement.

\section{Link to supporting question three.}

How does training impact on students' contribution to the school community?

- Leaders learn how to interact with diverse groups

- Leaders reminded to be role models

- Focus on relationships with student body. 


\subsubsection{Types of Leadership}

When talking about types of leadership, students in School B were focused on leading from the middle. There was a strong sense of the importance of the group and leading by example. One student said that a leader should involve people, especially those who are left out. Students spoke about the relationships and approaches effective leaders have as they make everyone else think they can do it, help them work as a team and help the group make decisions. One student saw that this involved having equality in the group. "To be a good leader I think you have to know when to follow as well like you can't be a leader all the time. Sometimes I don't know what I'm doing so I'll get someone else to step up" (Luke, 17, School B).

\section{Summary}

There is a strong sense of the importance of the group and leading by example. Students see the value of distributed leadership, showing that they value their groups and are working to empower others.

Link to supporting question two.

What do students gain from leadership training?

- Motivation to interact with the student body

- Ideas about leading groups

\section{Case Study Two: School B: Overall Summary}

School B has a range of leadership positions for Year 13 students. Leaders are elected and selected to lead the school as head students, house leaders and on the student exec. The house leaders run the house competition. The head students and student exec create and develop their roles during the year as they choose how to lead the student body. The school does not run its own training programme. Students are trained through their relationships with staff members and on external courses. Some external courses place students in leadership situations. Other external courses use motivational speakers to encourage action. Student leaders are keen to be role models and guides for the student body. 


\subsection{Case Study 3: School C}

\subsubsection{Roles}

School C has a variety of established leadership positions for students, which include peer support, peer mediation, student council, board of trustees' student representative and employment panels. The role of peer support leaders is the same as School A as they support Year 9 students and run peer support sessions during Term One. The difference is that the peer support leaders at School C go on a two-day camp with their Year 9 students at the start of the year

The council system works horizontally and vertically. Each form class elects a representative to be on the year level council and each year level council elects a male and female representative for the school council that is co-chaired by the co-board of trustees' representatives.

Students also lead through peer mediation. This involves students facilitating a conflict resolution process for students. Students apply, are interviewed, observed during training and then selected to join a team of peer mediators. The team is trained at the start of each year and they also advertise and promote the service at the start of each year. Most mediators run about two peer mediations a year. These can range from issues involving friendship break downs to bullying and acts of violence. Students also exercise leadership when new staff are hired. Applicants are interviewed by a panel from the board of trustees, a panel from the staff and a panel of students. The board of trustees' student representative position is jointly held by two senior students. Students can run as individuals or pairs in the board of trustees' election held in September each year. They attend monthly board of trustees' meetings.

Table 4-14 provides a summary of the comments made about the roles by the teacher, leaders and student body. It summarises what each type of participant perceives the roles of student leaders to be. 
Table 4-14: Leadership Roles at School C

\begin{tabular}{|c|c|}
\hline \multicolumn{2}{|r|}{ Leadership Roles } \\
\hline Participants & Comments \\
\hline Teacher & $\begin{array}{l}\text { Leaders } \\
\text { - } \quad \text { can lead in area of interest } \\
\text { - } \quad \text { council and BOT reps democratically elected by the students }\end{array}$ \\
\hline Student Leaders & $\begin{array}{l}\text { Council reps } \\
\text { - } \quad \text { relate news to their form class } \\
\text { - } \quad \text { bring ideas and concerns to the school council } \\
\text { Members of interview panel } \\
\text { - } \quad \text { provide student voice in employment process } \\
\text { BOT student reps } \\
\text { - } \quad \text { represent student perspective on the board }\end{array}$ \\
\hline Student Body & $\begin{array}{l}\text { Council reps } \\
\text { - } \quad \text { give feedback to form classes } \\
\text { Peer mediators } \\
\text { - } \quad \text { sort out trouble between groups }\end{array}$ \\
\hline
\end{tabular}

The teacher in charge of peer mediation at School C explained student involvement in leadership as:

whatever is there you can take ownership of and if you decide you want to do something then again you can do it so there's small leadership opportunities in the fact that students who want to start something up can start something up. (Megan, Teacher, School C).

The principal of the school presents this as an example of the school being based around democratic systems.

I interviewed five year level representatives from the school council. They see their role as linking the school council to the year level council to the form classes. One student encapsulates this in his definition of his role. "My role with that is trying to get the views of my year on any concerns they have about the school or any suggestions to make it better and ... help that become an actuality" (Jamie, 16, School C). This expectation of leaders is understood by the student body. One student defined it as "they give us ... feedback on meetings and if we have anything we go to them" (Anna, 15, School C).

The BOT student rep saw her position as being part of the team that was responsible for the general running of the school. She recognised that her leadership position meant that 
although issues of management could not be addressed at the board level, she could raise these issues with staff when possible.

The board of trustees is obviously a governance body it doesn't really deal with the management stuff but ... [we] are able to ... go to the principal or go to any of the non-teaching staff members and talk to them or even the teaching ones ... about management issues just because we're in that leadership position. (Claire, 18, School C).

As the board of trustees' student representatives are also co-chairs of the student council, this was seen as a place to raise management issues as well.

The student body identified their student leaders as: council members who were form class representatives, team captains and peer mediators. They did not mention peer support or the BOT student rep and interview panel specifically (although some of the students who lead in this way are also members of the council). For the roles they mentioned, they saw their leadership involving giving feedback to form classes, organising meetings and being assertive.

\section{Summary}

The leadership positions in School C are designed to involve students in the running of the school. This is an example of student democracy and students sense that the school is listening to them.

The aim of those on the student council is to try to get the views of their year across to those in positions of responsibility and power as well as concerns and suggestions about the school. The same motivation is obvious in the board of trustees' student rep role. Those in peer support, peer mediation and the interview panel see their leadership as service to the school. In all of their leadership roles, students lead as part of a team. This allows for consultation and collaboration, and students feel more capable of achieving their goals as a pair or group. 


\subsubsection{Current Training}

Table 4-15 summarises what was involved in each training session

Table 4-15: Current Training at School C

\begin{tabular}{|c|c|c|c|}
\hline \multicolumn{4}{|c|}{ Current Training } \\
\hline When & Who for & Provider & What it involved \\
\hline $\begin{array}{l}\text { December } \\
2009 \\
2 \text { Days }\end{array}$ & $\begin{array}{l}\text { Peer } \\
\text { Support } \\
\text { Leaders }\end{array}$ & School Staff & $\begin{array}{ll}\text { - } & \text { Overnight camp } \\
\text { - } & \text { Lectures } \\
\text { - } & \text { Practise at setting up peer support } \\
& \text { activities } \\
\text { - } & \text { Group discussion on peer support } \\
\text { - } & \text { Topics } \\
\text { Trialling Year } 9 \text { camp activities }\end{array}$ \\
\hline $\begin{array}{l}\text { December } \\
2010 \\
\text { Weekend } \\
\text { away }\end{array}$ & $\begin{array}{l}\text { Peer } \\
\text { Mediators }\end{array}$ & School Staff & $\begin{array}{ll}\text { - } & \text { Lectures } \\
\text { - } & \text { Role plays } \\
\text { - } & \text { Small group activities } \\
\text { - } & \text { Observations } \\
\text { - } & \text { Team building activities } \\
\text { - } & \text { High and low ropes course } \\
\text { - } & \text { Flying fox } \\
\text { - } & \text { Balloon babies } \\
\text { - } & \text { Simulated mediations }\end{array}$ \\
\hline $\begin{array}{l}\text { Term Four } \\
2009\end{array}$ & $\begin{array}{l}\text { BOT } \\
\text { Student } \\
\text { Reps }\end{array}$ & $\begin{array}{l}\text { Spirit of } \\
\text { Adventure }\end{array}$ & $\begin{array}{ll}\text { - } & \text { Sailing voyage } \\
\text { - } & \text { Governance training }\end{array}$ \\
\hline Unknown & $\begin{array}{l}\text { BOT } \\
\text { Student } \\
\text { Reps }\end{array}$ & $\begin{array}{l}\text { Trustees } \\
\text { Association }\end{array}$ & $\begin{array}{l}\text { - Meeting and discussion with other } \\
\text { BOT student reps in the region }\end{array}$ \\
\hline
\end{tabular}

A formal training programme is in place and run by school staff for peer support and peer mediation. As part of the end of year peer support training camp, the students trial the activities they will run on the Year 9 camp at the start of the following year - like making rafts, team building and an obstacle course. Ongoing support was provided in Term One when the peer support sessions were being run. Leaders met with the teacher in charge who would check their lesson plans each week.

The peer mediation training begins with a weekend away for the whole group including new and existing mediators. Students leading in this area learn about all aspects of the process, from the paper work for mediation to behavioural psychology. The teacher saw the training as developing valuable people skills.

Teaching them to be non-judgemental, aware of values and beliefs is probably the foundation to the whare in the sense that if students don't see that as being the 
major point of difference between people then it makes it very hard for them to accept situations, so we go through a lot of role plays and a lot of discussion around what their values are and what their beliefs are, how your values and beliefs are developed over time, who influences those values and beliefs and then how those values and beliefs can impact upon other people (Megan, Teacher, School C).

The programme has been developed over eight years by the teacher in charge. A guidance counsellor from another high school came in and ran it for them at first and since then the programme has been adapted through trial and error.

Peer mediators are then provided with supervision and have catch-up meetings throughout the year. Another aspect of the training was seen as the requirement to observe a mediation before running one, and that the first mediation someone does is with an experienced person. In this way students simulate, observe and share mediations.

Two formal training opportunities were offered to the BOT student reps in 2009. They were offered a place on the Spirit of Adventure ${ }^{14}$ course, which is run specifically for BOT student reps. The student I spoke to had previously been on a Spirit of Adventure trip so this opportunity was taken up by her co-rep. The other training was a one-off meeting provided at a regional level for BOT student reps.

Students at School C, like those at School A and B, see training for leadership as coming from experience, especially when dealing with people with different personality traits. One student reflected on the importance of looking inside yourself, which matches the selfanalytical idea of both of the head students at School B. Like students at School B, a student in School C saw youth conferences, the Youth Council ${ }^{15}$ and On The Edge as providing her with training for leadership.

The student council was not seen as a trained position but more of as a "learn as you go" leadership position. They learnt from the principal and BOT student reps who chaired the

\footnotetext{
${ }^{14}$ The Spirit of Adventure is a 10 day youth development voyage run by the Spirit of Adventure Trust which was established in 1973 to provide "a character development programme in a maritime environment" ("The Spirit of Adventure Trust," 2010)

${ }^{15}$ The Youth Council is run by the Wellington City Council. It consists of 20 members aged between 12 and 24. "It works on youth-related projects and advises the Wellington City Council on issues that affect the city’s youth.” ("Youth Council.," 2010)
} 
council meetings. The student on the interview panel also learnt leadership from being involved in the process. Students could look at questions from other panels to shape their questions, and also learnt from discussion with other panels for the final selection. The BOT student rep also saw her training as happening informally through experience, primarily through attendance and participation at the monthly board meetings. The students saw the goal of the peer mediation training ensuring they were a team and could all work together. They recalled exercises based around team building, the values session and mock mediations to show the different stages of mediation. They learn how to deal with people, how to get them to communicate and what best to focus on.

\section{Summary}

The current training is both formal and informal, depending on whether the leadership position is programme- or role-based. Those involved in the established programmes of peer mediation and peer support have training to prepare them for involvement with certain groups in the student body. These leadership roles have a direct impact on students' integration and happiness in the school environment. The roles of board of trustees' student representative, student council and interview panel are not part of a specific programme and are positions that relate more to the general running of the school. Training for these positions is informal and based on learning from experience.

\section{Link to supporting question one:}

What is the nature of the training given to student leaders?

- Formal and informal

- Practising activities from programmes they will run

- Weekend training camps

- Run by school staff

- Through experience learn as you go

\subsubsection{Effectiveness}

Aspects of the peer support and peer mediation training are seen as effective by students in School C. One student mentioned the discussion on cultural differences as useful in the peer support training and that the whole training camp meant that peer supporters were well-prepared for their roles the following year. The preparation was appreciated by members of the student body, who see peer supporters as people that Year 9 students look 
up to, who help Year 9 students get around school and as people who would look out for them.

Students who had completed the peer mediation training appreciated the training design and repetition. "It was very good in the way that it was able to bring the group together" (Blake, 16, School C).

It's good going back because even though you're going over the same stuff ... as you did the year before and the year before that ... you find that every year you do learn something new or you remember something that you forgot so that's quite good (Genevieve, 16, School C).

The importance of the role of peer mediator has been made clear. A member of the student body commented that mediators take their role really seriously. The promotional aspect of their training was also effective. Another member of the student body recalled that their role is that "if there's trouble in between groups then they sort it out ... well like try to help them" (Anna, 15, School C). From the teacher's perspective the peer mediation training makes a positive contribution to the school as it "grows the community and lowers conflict" (Megan, Teacher, School C). The peer mediators and the teacher in charge of their training listed similar qualities when asked what a good leader is like. These included being open, approachable, adaptable, flexible and non-judgemental. The teacher's ideas have been taken on board by some of the students.

The "on-the-job" training for the student council was seen as sufficient by the council members. The student who had sat on interview panels did not feel a negative impact from the lack of formal training as he believed the skills were gained during the experience.

The BOT student rep was positive about the training she had received. She appreciated the Spirit of Adventure training as it was primarily practical with follow-up feedback and reflection. The regional meeting with other BOT student reps was also seen as useful, mainly because it allowed students to mingle with other students who were in the same leadership role in different schools and to share ideas. She thought it was well timed:

we'd been to a few maybe three meetings or two meetings so we'd had a little bit of experience so that was good to go to the training after... otherwise we'd have no clue what anyone was talking about at the training (Claire, 18, School C). 
She appreciated having the previous reps at the first board of trustees' meeting so she could watch and learn about how to be on the board. Then her confidence grew through attendance at subsequent meetings. She also valued the other board members saying, "just talk to people and ask them questions is the best way of going about learning how to ... hold that sort of leadership position" (Claire, 18, School C).

\section{Summary}

Regarding peer mediation, students value learning about the four stages of mediation, questioning techniques and developing empathy. As a result of the training, students feel that the team bonded and they developed an understanding of values and beliefs. The BOT student rep saw that she had learnt the most from experience. This came from attending meetings. In terms of equipping students for leadership, the main evidence of this is in the skills and confidence the students gain. Specific mediation and peer support skills are taught through interactive sessions, which enable students to contribute to the school community. Confidence is gained by all students through the support and encouragement of staff. This growth in confidence allows students to feel capable of contributing to their team and fulfilling their role.

\subsubsection{Suggestions}

Table 4-16 summarises the suggestions for future training from the participants.

Table 4-16: Suggestions for Training: School C

\begin{tabular}{|c|c|}
\hline \multicolumn{2}{|r|}{ Suggestions for Training } \\
\hline Participants & Ideas \\
\hline Teacher & $\begin{array}{ll}\text { - } & \text { regular training } \\
\text { - } & \text { staff member responsible } \\
\text { - } & \text { based on training needs analysis }\end{array}$ \\
\hline $\begin{array}{l}\text { Student } \\
\text { Leaders }\end{array}$ & $\begin{array}{l}\text { - } \quad \text { provide lots of opportunities to lead } \\
\text { - } \quad \text { public speaking training } \\
\text { - } \quad \text { explain the requirements of the role } \\
\text { opportunities for networking with other leaders }\end{array}$ \\
\hline $\begin{array}{l}\text { Student } \\
\text { Body }\end{array}$ & $\begin{array}{l}\text { - develop on the job } \\
\text { - learn how to respect others }\end{array}$ \\
\hline
\end{tabular}

Opportunities for students to lead were considered valuable: "the more opportunities people are given to lead the more they're going to take those opportunities and the more they're gonna give back to the school" (Genevieve, 16, School C). Another student concurred and said, "some people kind of shine in their position and so then you find out 
that they really enjoy it ... give them the opportunities to be able to lead" (Rebecca, 13, School C).

The BOT student rep suggested preparing students for that role was essential training to make sure candidates knew the difference between management and governance before standing for the position. She also thought schools could run school-specific training for their BOT student reps. Another suggestion she had was that it might be useful to have a catch-up regional meeting for BOT student reps or student council members, which might include discussion on how to "effectively voice student opinions" (Claire, 18, School C).

Two members of the student body suggested that training was not always necessary. One student believed that only peer mediators needed training. She thought that, if the right person was selected for other roles "someone who is quite confident and who is sort of just like a natural leader then they don't really need to [train them]" (Anna, 15, School C). The other student thought that students would deal with situations when they were in their leadership role, developing and adapting to it. Suggestions for ways of working with people were also given. One student thought it was important that student leaders were trained in how to respect others in order to understand what people have been through.

\section{Summary}

The key suggestion is to give students opportunities to lead so that they are able to find out about leadership and learn from the experience. Training should also involve learning about the role and what expectations are associated with it. Students are also seen to learn from others in leadership.

\section{Link to key question}

What constitutes effective leadership training in New Zealand Secondary Schools?

- Preparation for running programmes

- Reinforcement of key skills

- Learning through experience

- Repetition of training

\subsubsection{Community Connections}

There are a number of staff members who are directly responsible for groups of student leaders. The principal coordinates the school council, leading by example. A teacher and a 
guidance counsellor train and support the team of peer mediators. Another teacher runs the peer support programme. The students also mentioned their year level deans who attend and keep year level council meetings on track. The deans also recognise leadership potential and direct students to courses. The BOT student rep had experienced conferences and meetings with staff to raise student concerns.

Leaders saw themselves as representing their year level on the student council and providing the student body with a link to staff. A Year 9 student commented on the positive effect of the peer support programme. She identified it as helping her get to know others and making the start of school less daunting. She appreciated their willingness to do activities with them on camp and having a "familiar face" (Rebecca, 13, School C) around the place.

The student body has a positive view of student leaders, suggesting that they provide a service to the school community and help integration of Year 9 students into the school. They appreciated having people who knew what was going on, gave up their free time to lead, which included being organised and allocating jobs. Another student valued the way student leadership provided a place for students to freely debate issues:

you can talk to them as if you're talking to a friend whereas with teachers ... there's more a clear divide ... they're a power and ... you've got to give them respect and they can punish you for anything and ... you can't really do anything about it ... whereas other students you can have like a debate without getting in trouble (Sophie, 17, School C).

Regarding the team aspect of their leadership, the students on the school council appreciated that, because all year levels were treated as equals, there was an equal sharing of ideas. Because of the intensive and yearly training and the emphasis on understanding values and beliefs, peer mediators felt that they were able to bond as a team and "find common ground" (Blake, 16, School C).

\section{Summary}

Staff facilitate and enable student leadership: running training sessions, attending meetings and supervising activities. The main link leaders have with the student body is in providing the student voice to management. They also provide a service to the school community through peer support and peer mediation. 
Link to supporting question three.

How does training impact on students' contribution to the school community?

- Peer support leaders help integrate Year 9 students into school life

- Peer mediators provide a conflict resolution service

- Student council members learn to share students' ideas with staff

\subsubsection{Types of Leadership}

Students in School C referred to leading from the middle and leading from behind when talking about leadership. Leading from the front was not mentioned. Students see that leading from the middle means being involved and keeping the group together. It involves being able to relate to others and establishing a level of authority. The leader in this situation was seen to have "a vision to show other people what they're capable of and what they can achieve ... as a collective" (Claire, 18, School C) and communicate this well to their group. One student described her ideal model of leadership as leading from the back, which meant putting others ahead of yourself. She explained:

I think a good leader is someone who leads from the back ... they're not really showy and they're in that position not necessarily because they're the best at whatever task you're doing but because they have the qualities to be able to get everyone motivated and doing what they're meant to be doing (Rebecca, 13, School C).

She recognised it was often ineffective to tell people what to do and it was more important to be involved in doing what was required.

\section{Summary}

Students perceive that it is important to be actively involved in the activities of the group you are leading. This allows for leadership to be from the middle and from the back. People skills are seen as vital when leading in this way in order to have authority and motivate others.

\section{Case Study: School C: Overall Summary}

School C has a range of opportunities for students to lead as part of a team. Leadership positions include peer mediation, peer support, interview panel, BOT student rep and student council. In the positions on the interview panel and student council as well as BOT 
student rep, students provide the student voice in the running of the school. Informal training is given to the elected members of the school council as well as to those on the interview panel. The BOT student rep is also trained in this way, as well as by external providers. These leaders learn from experience. Formal training is provided to peer support leaders and peer mediators by school staff. These students serve the school community.

\subsection{Survey Results}

The final stage of the data collection was a survey of the student leader participants to check some of the emergent ideas from the interview stage about effective student leadership training. See Appendix D for a copy of the survey. The survey was designed to summarise ideas about good leadership and effective training suggestions. Another aim of the survey was to discover each participants' thoughts about their training and leadership experience towards the end of the year.

The results of the survey are reported here to provide a summary of views across all three schools. This provides a bridge from the individual case studies to the discussion of key themes in Chapter 5. There was a $70 \%$ rate of return. 16 of the 23 student leader participants completed the survey. The results give an indication of ideas and experiences rather than a complete reflection of opinions.

The first survey question asked students to provide an opinion on what a good leader is. This question was made up of ten phrases for students to rank using a five point Likert scale. The points on the scale are:

- Strongly Agree

- Agree

- Neither Agree nor Disagree

- Disagree

- Strongly Disagree.

The phrases were a combination of statements that recurred in the one-to-one interviews (numbers 1, 2, 4, 5, 6, 8 and 9 below) and statements constructed to test whether students preferred leadership from the heroic (numbers 7 and 10) or distributed (numbers 1 and 3) mode of leadership. Results from all participants are combined. The list below shows the ranking of the characteristics of a good leader in descending order from that chosen most often to least often. 
1. Leads by example

2. Motivates others

3. Is part of a team

4. Serves others

5. Makes decisions

6. Resolves tension

7. Makes things happen

8. Is knowledgeable

9. Is a good public speaker

10. Tells people what to do

Ranking "leads by example" as number 1 shows that student leaders like leadership that is authentic. Ranking "motivates others" as number 2 shows they also like leadership that is encouraging. Leading by example had two students agree and 14 students [ $n=16]$ strongly agree as an aspect of a good leader which reveals that student leaders think leaders should model behaviour for others. There was more support for leading from the middle than leading from the front.

Participants were then asked to choose three words from a list that they consider to be the most important characteristics of a good leader. The qualities were also taken from suggestions given in the interviews. The results are shown in Figure 4-1.

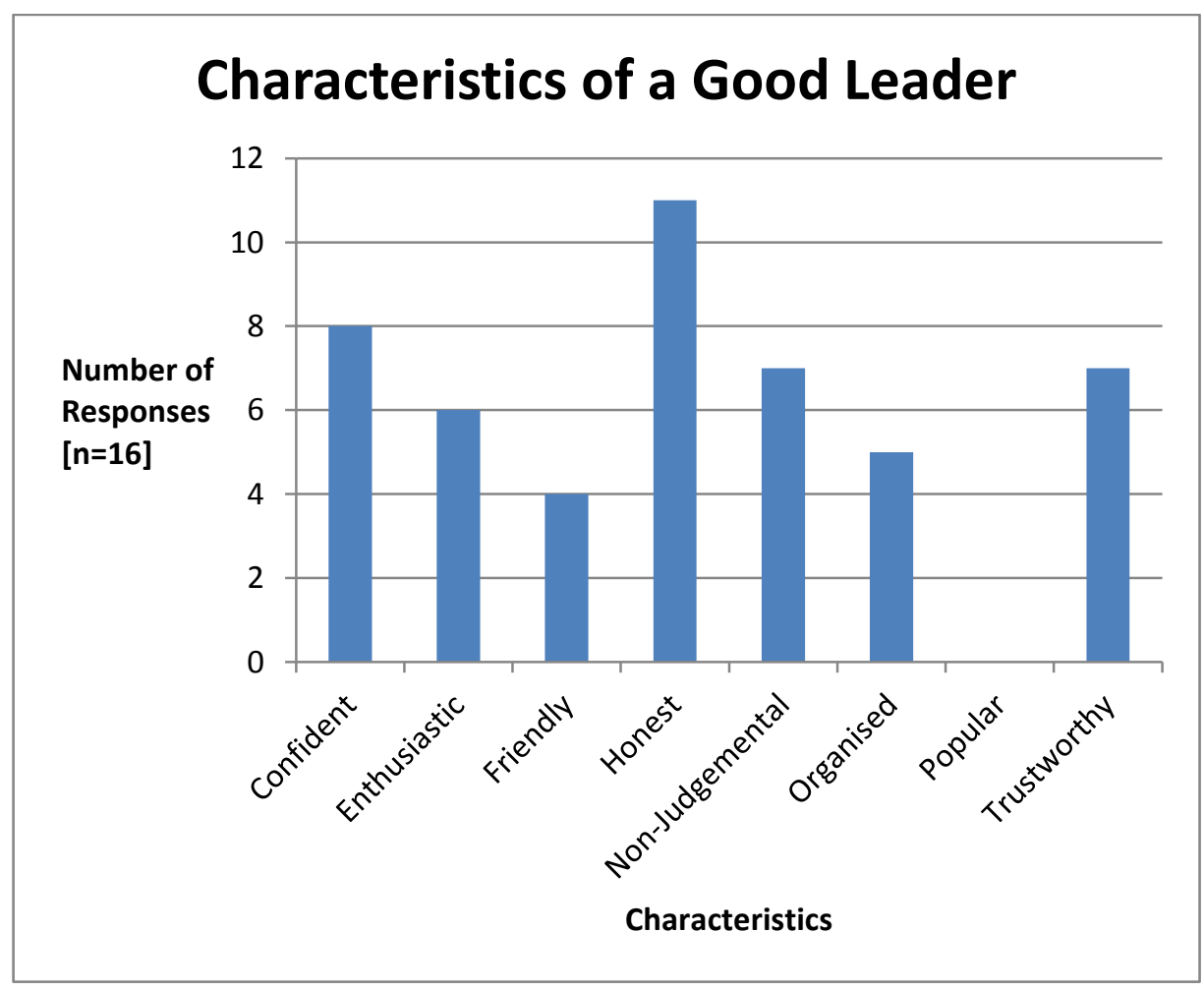

Figure 4-1: Characteristics of a Good Leader 
As "honest" was chosen the most frequently, these results suggest that integrity and positive personal relationships are valued over status, signified by the fact that no one chose "popular".

The next set of questions, shown in Figures 4-2, 4-3 and 4-4 are based on training experiences.

Survey Question 3: I have taken part in student leadership training.

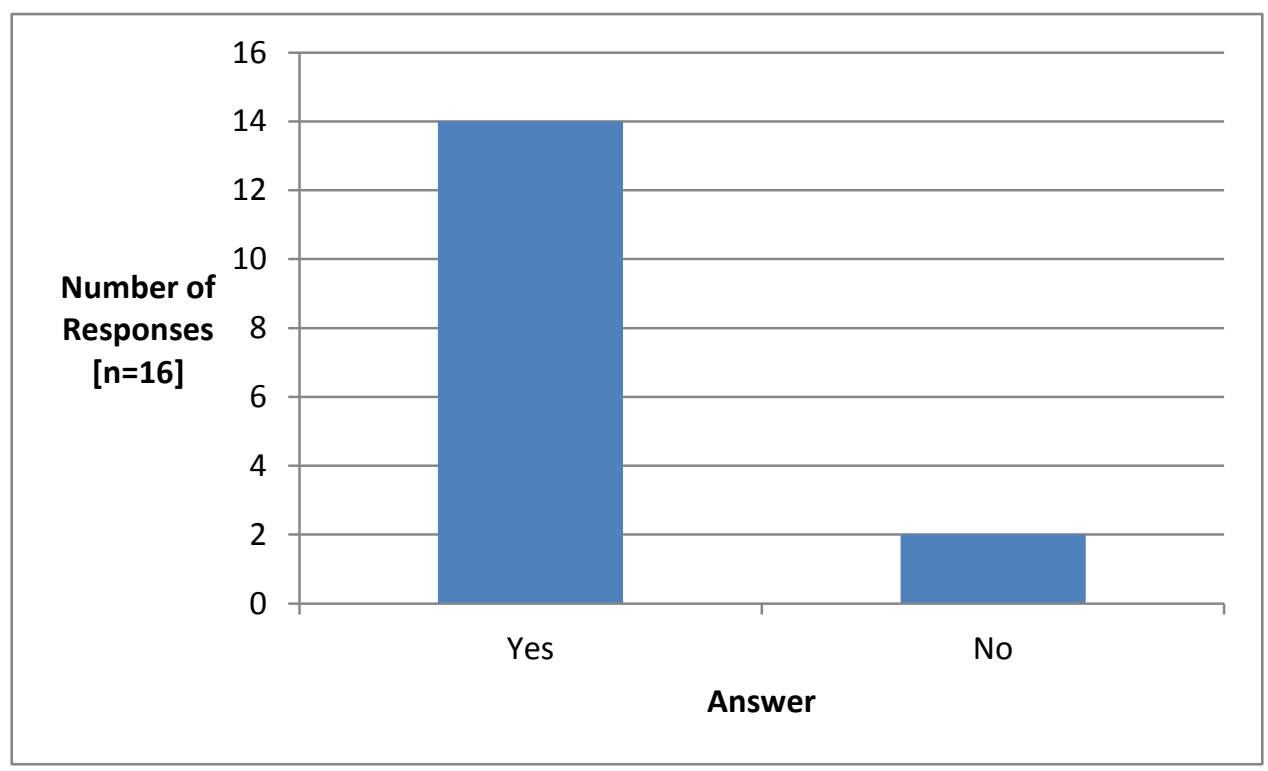

Figure 4-2: Participation in Student Leadership Training

Survey Question 4: Overall, the student leadership training I took part in was effective in helping me become a good leader.

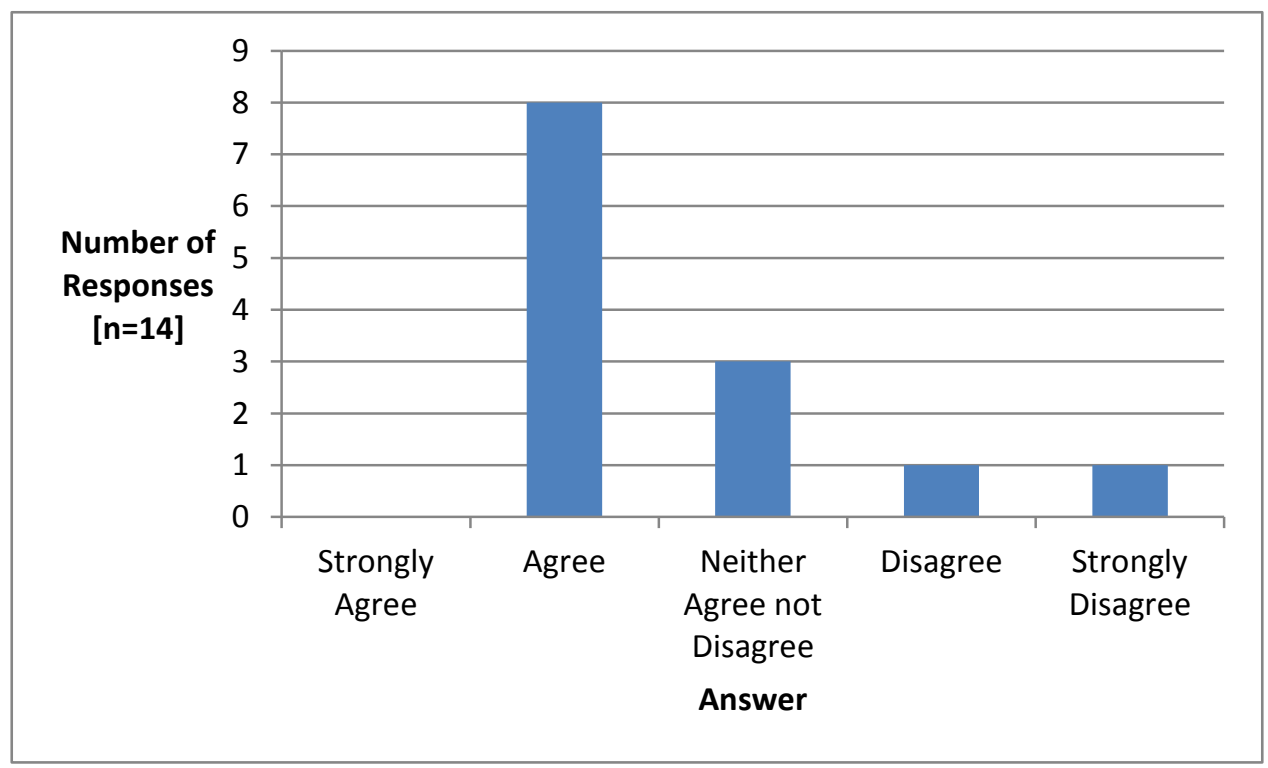

Figure 4-3: Effectiveness of Training 
Survey Question 5: I have been able to put the leadership training I have received into practice this year.

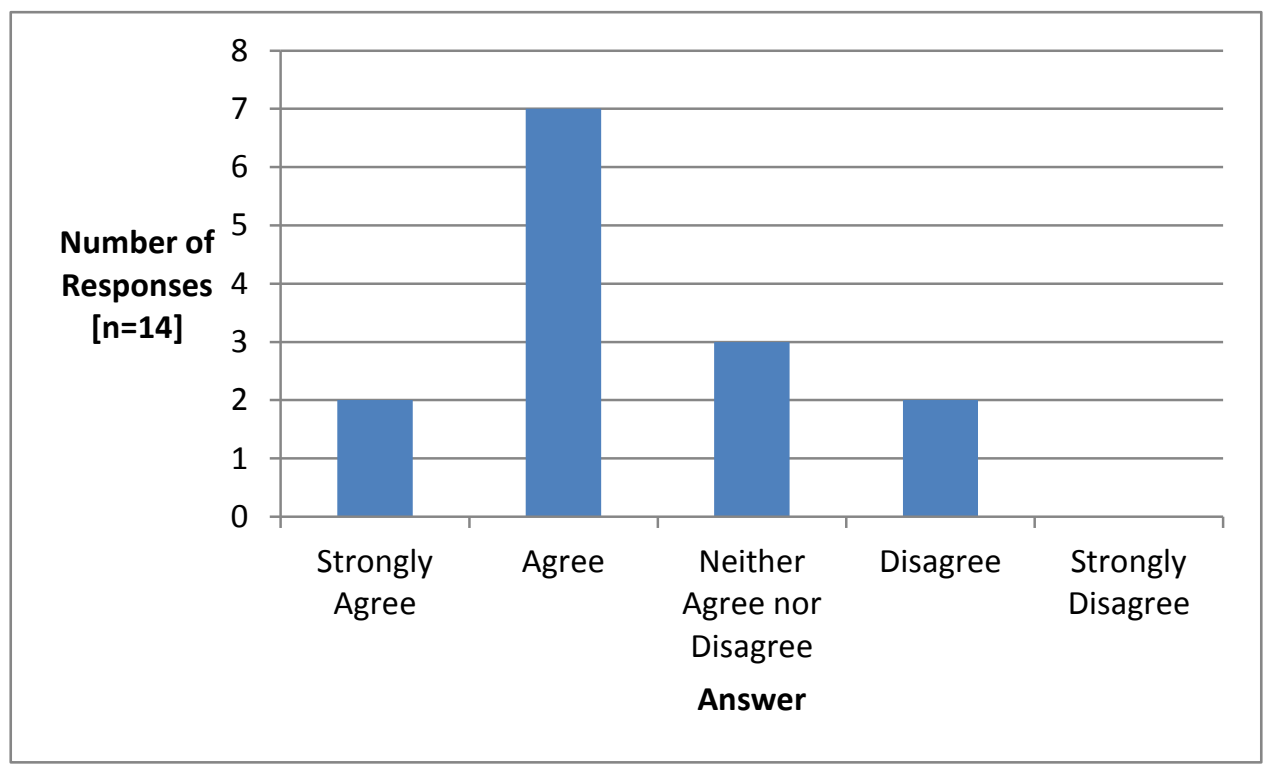

\section{Figure 4-4: Training into Practice}

These results suggest that a few students had a negative training experience, but most students found the training effective and useful.

Students were then asked to rate ten training suggestions according to how effective they would be in developing leaders. These suggestions were constructed in two ways. Some were examples of training already provided by schools and some were common suggestions derived from the interviews with participants. This is the list in order of what student leaders consider would be most effective to least effective.

- Get previous student leaders to give advice.

- Buddy student leaders with younger students who need support at school.

- Get the principal to talk to student leaders.

- Have senior student leaders work on projects with junior student leaders.

- Send student leaders to a leadership course.

- Team building exercises.

- Provide student leaders with a teacher as a mentor.

- Give student leaders a group to lead.

- Provide opportunities for student leaders to meet with student leaders from other schools.

- Have experts come to school to give student leaders training sessions. 
The two most popular suggestions for future training suggest that student leaders consider their peers to be helpful in providing training. Using the voice of experience from previous leaders and buddying leaders with younger students also shows the desire to focus on the school community, utilising the resources at hand. Students also value experiences that teach them something about their leadership situation - as seen in the third choice for getting the principal to talk to them. Suggestions 4 and 7 again show the value placed on the use of initiatives from within the school context, whereas two of the suggestions that involve outsiders rate the lowest. Student leaders seem to appreciate learning about leadership and doing leadership with people they know in the school environment.

The next set of questions asked participants to reflect on their past and present experiences of leadership. They were also asked to consider their future expectations in the area of leadership. The results are shown in Figures 4-5 - 4-8. Students were asked to respond to these statements:

Survey Question 7: I am doing a good job as a student leader.

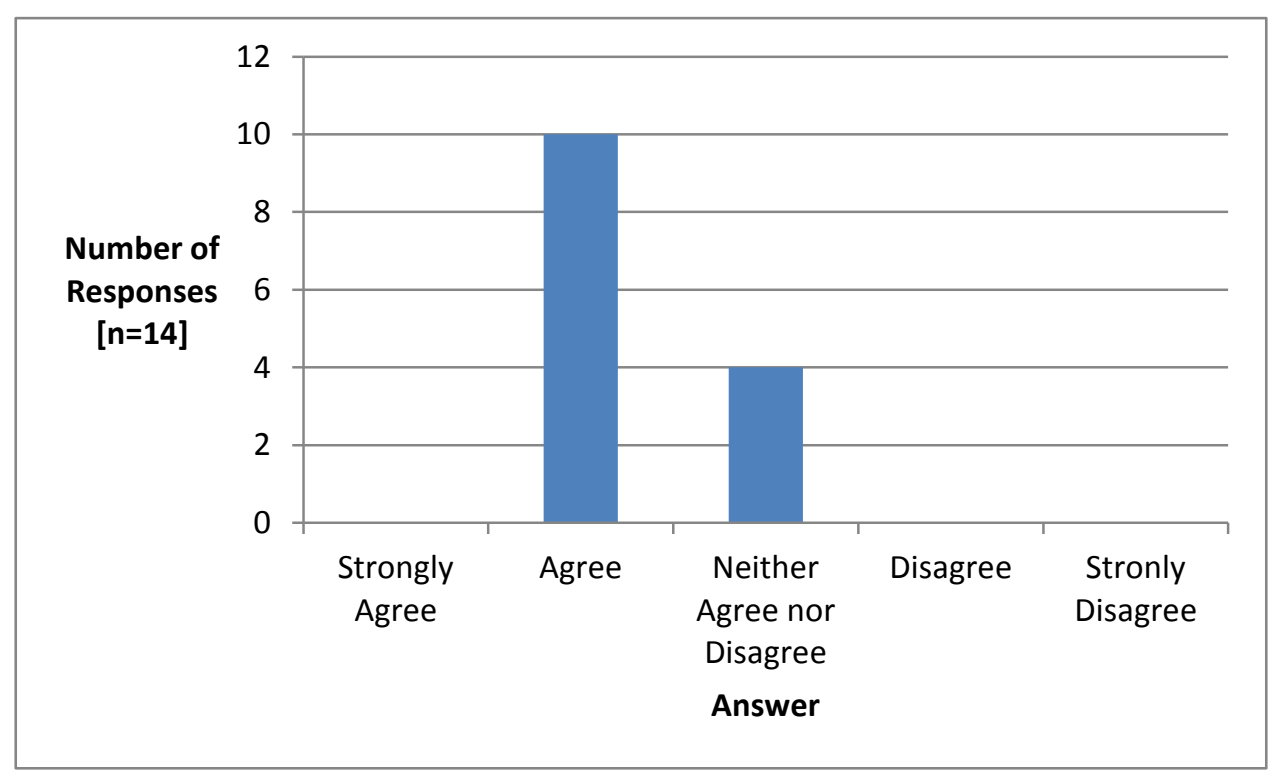

Figure 4-5: Good Job as Student Leader 
Survey Question 8: I have made a positive impact on the school community this year.

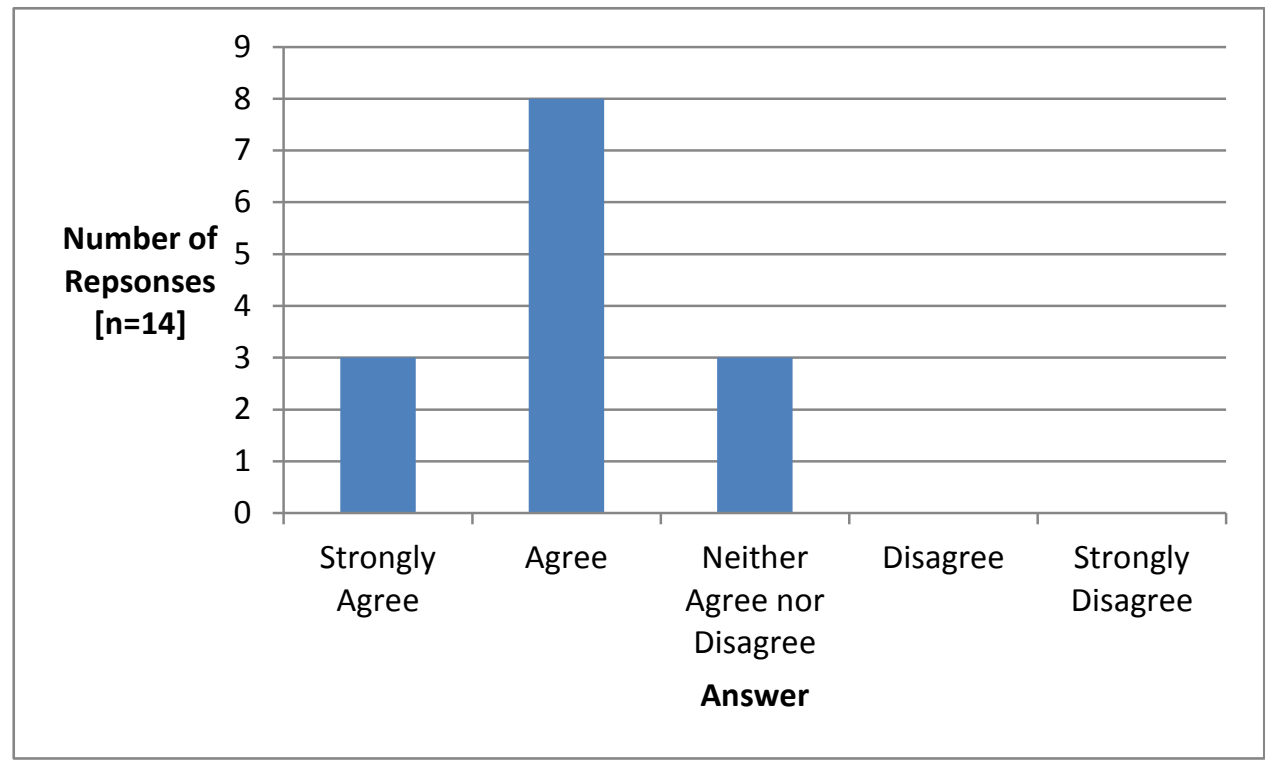

Figure 4-6: Positive Impact on School Community

Survey Question 9: I am developing as a leader this year.

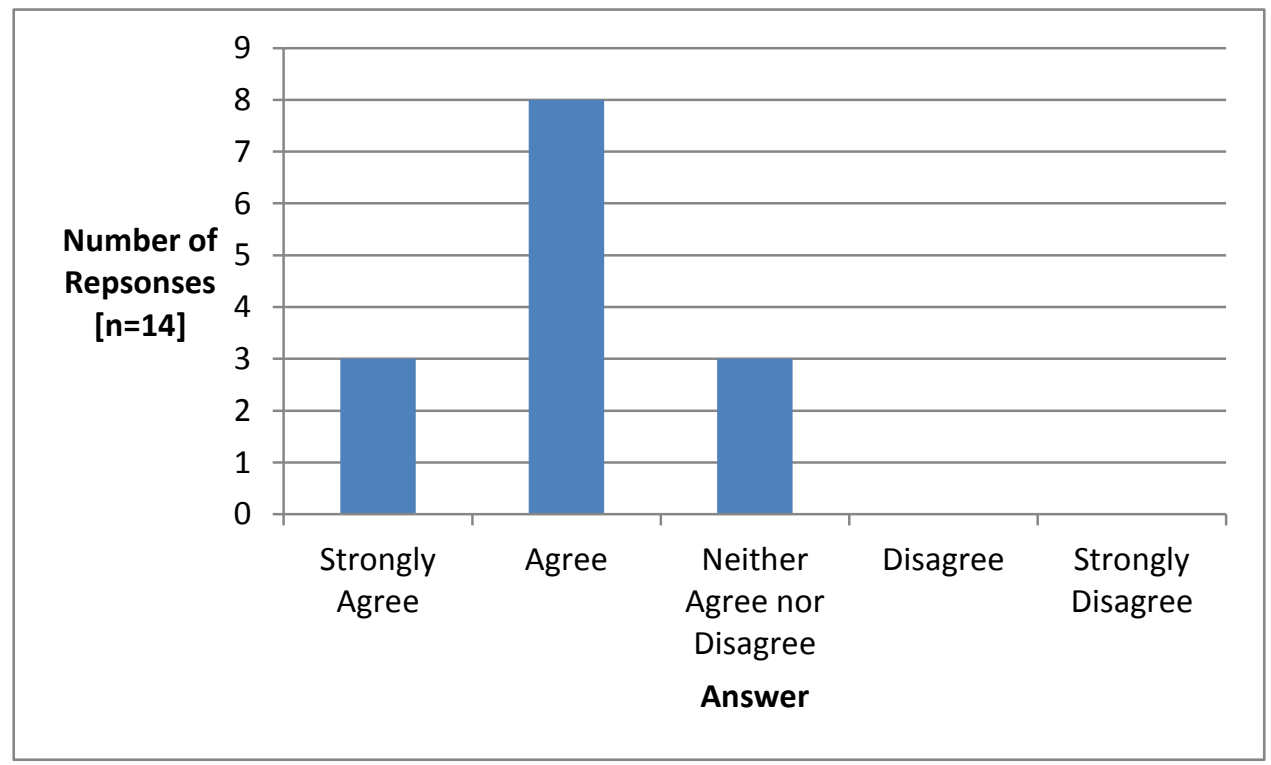

Figure 4-7: Leadership Development 
Survey Question 10: I plan to be in a leadership position in the future.

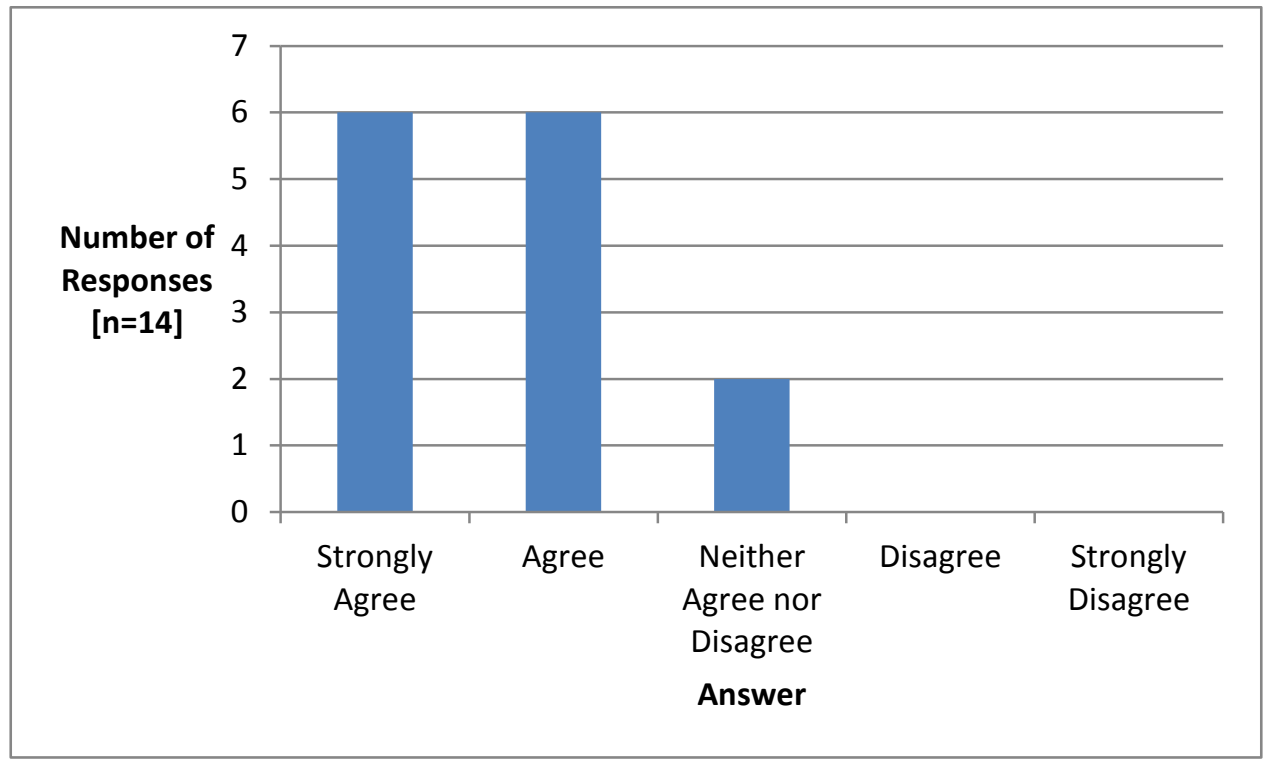

Figure 4-8: Future Leadership Plans

These results suggest that the majority of students have a positive experience as a student leader. Ten to twelve students were in agreement to some degree with each statement, which implies that they feel good, useful and experience a sense of growth while leading.

These survey results give a picture of the type of leaders and training students prefer. Students see leadership and training as people-focused. An ideal scenario would be for students to develop interpersonal skills that enhance trust in the school context as part of their training. 


\section{Chapter 5: Discussion}

\subsection{Overview}

A number of key themes have emerged from this investigation into what constitutes effective leadership training in New Zealand secondary schools. The type of training provided and its effectiveness differs in each case study school. Despite these variations, it is possible to compare schools and see similarities regarding what constitutes effective leadership training. By combining the voices of teachers, student leaders and the student body from all three case study schools we can hear how schools could approach leadership training and what they could do when training student leaders. The six key themes:

- distributed leadership for students

- leadership identity development

- the school environment

- students as role models

- leading from the middle

- learning by doing

are introduced in the two sections below and are discussed in the subsequent sections of this chapter. Recommendations for schools based on the research findings are also integrated throughout this discussion.

\subsubsection{Approaching Leadership Training}

Student leadership training is not an isolated phenomenon. It is a product of a school's values and philosophy on teaching and learning. By learning about the environment in the case study schools, it is possible to see what attitude schools could take towards student leadership. The results of this research suggest that it is important for schools to develop some ideological approaches to student leadership before they design specific training programmes. One of the first considerations is how to implement distributed leadership. When considering student leaders and how to train them, schools should also focus on encouraging leadership identity formation. By helping students see themselves as being on a leadership journey, schools can foster the development of capable leaders. In order to have students that are well prepared for leadership, schools can also focus on their situation and develop a school environment that supports student leadership. 


\subsubsection{Designing Leadership Training}

This research suggests that leadership is informed by the situation, therefore one model of leadership training will not be effective in all schools because each situation is different. This means that each school will need to design a leadership programme to suit their school. However, by looking at what works well and what seems to be needed in all three case study schools, it is possible to suggest some components for the design of effective student leadership training programmes. These include preparing students to be role models, reinforcing the importance of leading from the middle and focusing on being a team. Students will also benefit from training that combines theoretical and practical activities. Finally, this research shows that the most effective strategy is to allow learning by doing. Leadership training should be based on providing opportunities for students to experience leadership.

\subsection{Distributed Leadership for Students}

Distributed leadership among secondary school students happens when leadership is shared and occurs in the collective interactions between the situation, student leaders and the student body (Spillane, 2006). It is founded on interdependence and coordination (Gronn, 2002b) and can be encouraged by aspects of leadership training.

In all three case study schools leadership is "stretched over multiple leaders" (Spillane, 2006, p. 15), which is a feature of distributed leadership. The members of the leadership teams are in relationships of interdependence. The nature and extent of interdependence depends on how roles are defined. Roles may be based on detailed job descriptions or general expectations. Different roles were present in the three case study schools. Prefects in School A have the same role and create their team leadership style during the year. Role overlap like this means than there is less likelihood of error or lack of leadership (Gronn, 2003a). The prefects have a sense of being a collective. Spillane refers to this method of arranging leadership responsibilities as "parallel performance” (Spillane, 2006, p. 40) created by design. It is also an example of "collective distribution [where] leaders work separately but interdependently to co-perform a leadership routine"(Spillane, 2006, p. 64).

The various roles in School B mean that students share ideas but may be displaying leadership qualities individually in specific areas and rely on each other less. This is an example of "coordinated distribution" (Spillane, 2006, p. 66) when leaders can work 
separately or together on a sequence of tasks complete the routine. This is in evidence when all the house leaders meet and plan together and then lead their house in smaller leadership teams to complete the routine of the house competition.

School C has a number of leadership teams that are interdependent when working on designated tasks such as the school council and peer mediation team. "Collaborated distribution" (Spillane, 2006, p. 66), which is people performing the same leadership routine, is in evidence in the leadership of the co-BOT reps.

There is evidence in at least three leadership teams of what Gronn (2003a) terms emergent interpersonal synergies from close working relations. In School A, during the training session I observed, prefects encouraged each other to plan new initiatives for building school spirit. The head students in School B are keen to develop the position according to their combined strengths. The BOT student reps in School C strategise together about how to communicate the requirements of the role to new candidates. The student leaders are exemplifying distributed leadership through "concertive action" (Gronn, 2003a, p. 35) where leadership is collaborative, spontaneous and involves intuitive understanding between close colleagues. The student leadership teams also exhibit "conjoint agency" (Gronn, 2002b, p. 318) as students synchronise their actions by considering their own plans, their peers and their sense of belonging to the leadership team.

Distributed leadership requires leadership teams to understand how the student body helps to create their leadership practice. There was some evidence of this in School A as participants considered how prefects' leadership was affected by their friendships with members of the student body.

Each type of leadership training in the three schools aimed to equip students to interact with the student body effectively. Students were encouraged to consider how they were perceived by others and how they could show leadership in the school context. However, in all three schools, deeper understanding of leadership practice could be achieved by defining and describing how the student body interacts with the student leaders. This could be introduced and facilitated by student leaders from previous years. It could be argued that preparation in this area would increase confidence and build leadership capability.

Distributed leadership also requires an understanding of tools and routines in the leadership context. Head students, house leaders and members of the student exec in School B and the 
BOT student rep in School C who were sent on external training courses appeared to lack this focus in their preparation for leadership. School-based training in School A for prefects and peer support leaders, and in School C for peer support leaders and peer mediators that focused on preparing student leaders for their role in day-to-day school life or for delivering specific programmes, tended to emphasise the ideal situation for leadership. This included how students could inspire and teach others.

It may also be necessary for training to include a critique of school culture. Students will be able to see which tools and routines in their school situation facilitate and restrict leadership practice (Spillane, 2006). There was some evidence of this in School C in peer mediation training through mock mediations and in School A during the training when students discussed difficulties in their leadership context. The response of students in School A to try to create new traditions shows they see both negatives and positives. At the training session when they decided on this approach, they saw the instruction from school management not to run some whole school events in the same way as they had been run in the past as a negative factor, with the opportunity to take initiative and run new events as a positive factor. Students need to be prepared for the reality of their leadership situation because, from a distributed leadership perspective, it will define their leadership practice.

Allowing for growth in leadership experience and involvement is another aspect of distributed leadership. There was evidence in all of the case study schools of students learning from each other and other members of the school community. However, for schools to practise distributed leadership, there also needs to be some blurring of the boundaries between student leaders and the student body so that leadership development can be encouraged. This may run counter to the aims of some schools that reserve leadership status as something for students to aspire to in their last year of school. The new paradigm of distributed leadership is interested in a school's total capability for leadership rather than an old emphasis on a select few leaders (Gronn, 2003a).

Interdependence and shared leadership should be encouraged by school management and teachers responsible for student leaders. As leadership teams are trained and work together they will engage in teamthink (Gronn, 2003a) which is when a group pattern of thinking develops. This is seen as likely to bring consistency and stability in a school situation. 
Application of the principles of distributed leadership is likely to be effective in training student leaders. It can be implemented in New Zealand secondary schools.

\subsection{Leadership Identity Formation}

One of the key suggestions from the literature regarding leadership is for students to see themselves as a leader in any situation. This is shown in the experiences of participants in each of the case study schools. Schools can encourage students in this development. Understanding how students see themselves as leaders can form a springboard into developing effective leadership training programmes for schools. Schools can use this to confirm or challenge perceptions.

As mentioned in the literature review, Leadership Identity Development (LID) is a model developed by Komives et al. (2006) to describe the leadership development process. A condensed version is supplied in figure 5-1. It is a useful tool to explain what occurs as students grow into leadership. The authors comment on the importance of relationships in creating a personal identity as well as thought processes, especially reflection and responsibility. Komives et al. suggest that most high school students are at stage three in the LID model. During their senior years at secondary school, student leaders may make a key transition into stage four. Schools and educators may find this LID model helpful for planning, designing and implementing leadership training programmes appropriate to a student's age and stage of development. 


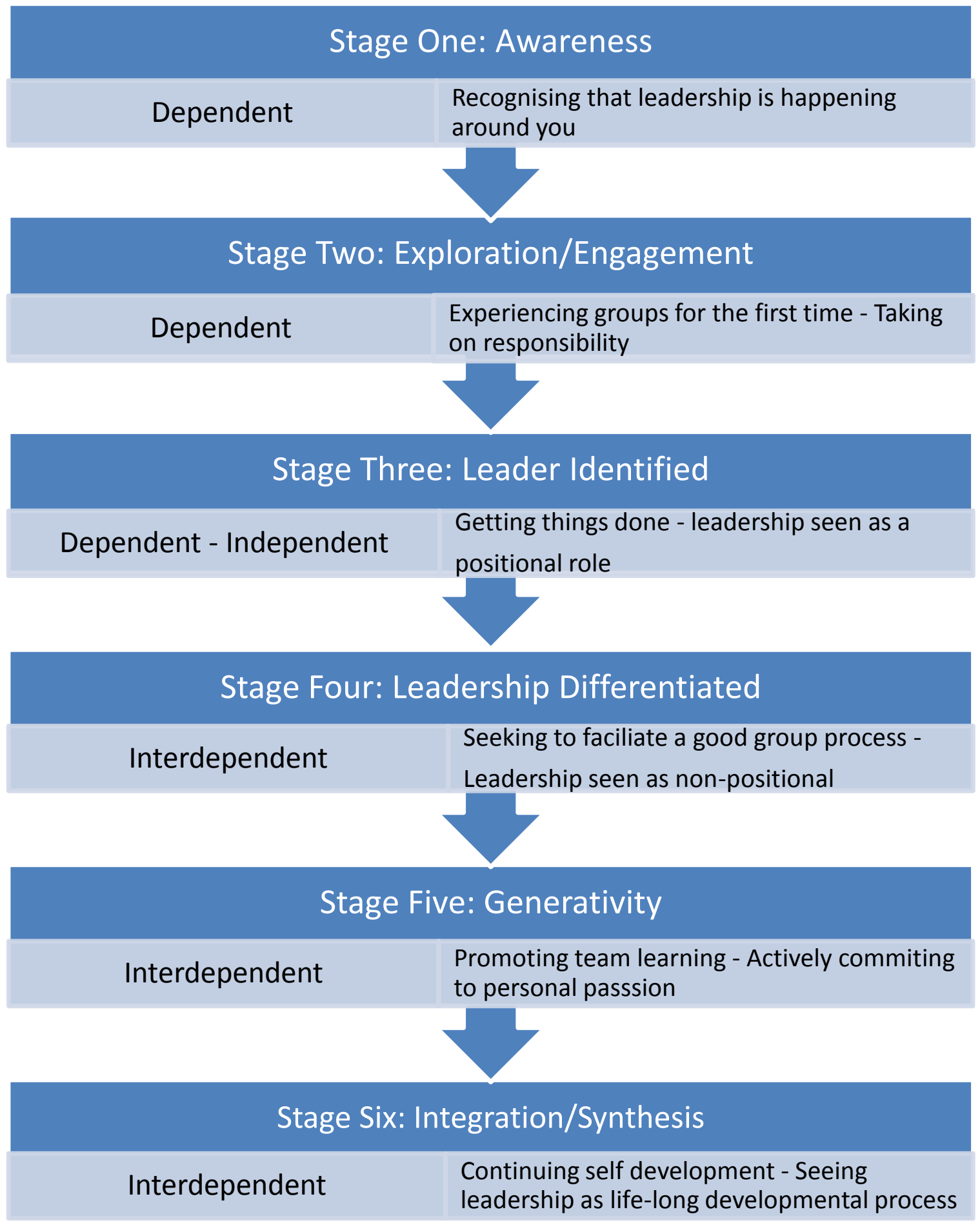

Figure 5-1: Leadership Identity Model (LID) adapted from Komives et al. (2006, p.434).

Students at all three schools were at various places in their leadership identity development and showed an ability to be reflective about leadership in general and in their own leadership experiences. As this theme has a personal focus, quotes from my participants are used to express key ideas on this topic. 
Twelve students across the three schools clearly realise leadership is more than a position, job or title. One student explained that:

you don't change as a person when you get a prefect badge you just continue. It's another step so it's ... not something we specifically need a lot of training we're probably mature and responsible enough to take it on when you get it (Riley, 17, School A).

At School A, in the general discussion during the training I observed, this idea was repeated. A student at School B was convinced that leadership was a personal experience and was reluctant to be labelled. He felt a sense of confusion because he saw leadership as one person in front telling people what to do, but that concept did not fit with his experience or reflection. He confirmed the suggestion that "the heroics of leadership genre has a stranglehold on how we think about leadership" (Spillane, 2006, p. 103). The student explained:

it's hard cos when I was little ... younger at intermediate and stuff people were like you're gonna be a leader when you're older you're a leader I didn't consider myself a leader I'd ... sometimes I still don't ... sometimes I just see myself as another person in the group just doing what I do best and people like oh you're a leader (Luke, 17, School B).

When probed as to why this was he said "people watched me and followed me I guess". Another head student at School B explained "[I would] like our leadership to just ... come naturally and I want us ... to find it within ourselves" (Aisha, 17, School B) instead of being constrained by a job description. This suggests her sense of leadership being individual and tied to identity. Students who are progressing from Leader Identified (Stage 3) towards Integration/Synthesis (Stage 6) of leadership identity development dislike being confined in the way they show leadership, and would rather have leadership as part of their personal sense of identity. It is worthwhile schools considering how to facilitate this process.

Reflection has been identified as a necessary skill for leadership development (Komives, et al., 2005). As explained in the survey results, when students reflected on leadership characteristics, their top three were honesty, confidence and trustworthiness. One student at School A commented that "I'm not sure you can specifically pin down ... what a good 
leader is" (Ethan, 17, School A), perhaps in recognition that it is tied to individual identity. Some suggestions included the ideas that you "don't just focus on one thing and you are an all round student" (Angus, 17, School A), and you need to "know what the right thing to do is ... make sure you know what you're doing" (Connor, 17, School A). This matched up with the teacher's goal at School A that students would learn about the responsibilities of leadership from the training they received. The School B teacher also commented on leadership identity being based on reflection, explaining that student leaders "needed $a$ strong sense of who they are and follow what they believe in" (Sarah, Teacher, School B).

Students questioned whether leadership and being a unique person were the same thing, and whether event management was leadership. The range of ideas that the leaders shared showed that a number of them were well on their way to seeing leadership as an aspect of their identity rather than the position they held. A number of students are questioning what leadership means for them personally. As they form their leadership identity, they show evidence of reflection and understanding.

Part of leadership identity development, linked to reflection, includes the ability to critique aspects of student leadership. At all three schools, students raised a few concerns. During the leadership training I observed at School A, it appeared that there was a sense of resentment from some students that the school had placed some restrictions on them. In the interviews, one prefect explained that they need more opportunities to lead and role modelling was not enough. Three students at School B felt that they did not have enough to do, and the reality of leadership was different to the experience. "We haven't done as much as I expected we were gonna do" (Aidan, 17, School B). It seems that leadership is tied to a sense of ownership regarding roles and responsibilities. Despite having some criticisms and concerns, the student leaders are all committed to the leadership journey. This is obvious as $86 \%$ of survey respondents either agree or strongly agree that they plan to be in a leadership position in the future.

Leadership was seen by students and teachers as developing over time. A number of students commented on the sense that their leadership had developed throughout their schooling. Students saw that the school provided opportunities for them to develop as leaders because leadership did not just begin when given a job. They were already involved in school life and were encouraged to volunteer for service roles. One student saw that being a leader at school was the school's attempt to try to teach them skills for the 
work force. This shows he was able to think about leadership as unrestricted to one place and time.

A student thought she had learnt a lot by single-handedly running the school's 40 Hour Famine. She had attended a World Vision training camp without realising that the camp was for those who were taking on this task in their schools. She explained:

I really enjoyed it and I discovered on the camp in being part of this camp I was putting my name forward to run the 40 hour famine at my school for that yeah and I was like oh whoah ... I was the only person from my school ... whereas all the other schools ... had two or three or four other people and I was by myself ... so that made me really sort of stressed and overwhelmed (Claire, 18, School C).

Despite this situation, she seemed to have developed a sense of satisfaction from getting people to take part and raising money. This situation, though initially stressful, helped her gain confidence in her leadership ability and helped form her leadership identity.

Regarding the school context, the teacher at School C thought the range of opportunities was a strength for the school. She was proud of the peer mediators who have gone on to apply their school leadership skills later in their professional lives. For two students from School C there was a sense of teachers understanding their abilities. One was sent to courses by her dean who she saw as having sound judgement of her character. The other knew a teacher through sport and because this teacher knew she was interested in leadership, he had suggested she attend the World Vision 40 Hour Famine training camp. These examples support the advice from Komives et al. (2006) that staff should support and challenge student leaders as they learn to see leadership as a process rather than a position. Schools provide opportunities for growth and establish relationships that facilitate growth.

A number of key relationships, some previously mentioned, were significant in the leadership identity development of student leaders. The teachers who spoke at the first leadership training session at School A were seen as helpful because they taught the students about an "ethically correct approach" (Angus, 17, School A). Pre-existing ideas about leadership were challenged. Students from all three schools talked about looking up to, and learning from, previous leaders. They were seen as informing their actions and leadership style. The students at School A were in consensus that they had looked up to 
older prefects and wanted to emulate them. For example, one student explained that he had experienced the general caring nature of past prefects and he wanted to try to take this approach as a leader himself. One student explained that he had wondered previously how prefects had managed to cope and had figured out from his own experience that it was a team effort where everyone got involved. As well as learning about leadership styles from the training, one student commented that he had spent four years:

watching other people try and then you can see what comes across well or doesn't come across well and who you think's doing the job and who isn't and ... use that to figure out ... what you will be ... and how you want to act (Ethan, 17, School A).

Another student at School B thought he had developed as a leader by being a follower and looking up to other leaders. In this way he wanted to be like them. He talked about looking back on experience and "seeing the way the ... other people act as leaders just makes me want to try and be like that ... like previous leaders and I see how they used to act and I wanna be like that" (Aiden, 17, School B). This is evidence of reflection on previous leaders that led to greater awareness. These comments show the value of using previous student leaders in training programmes.

Each student is forming a leadership identity. Students may move from considering leadership as a position to thinking of leadership as part of who they are during their last years at secondary school. Schools can aid and support them in this process. From the ideas expressed by students, it is clear that leadership identity is moulded by the context and relationships each student has. The words, examples and expectations of others are important to the students. They are interested in how they can serve others and be effective group members.

Ideas about leadership identity development from the three case studies can be used in the design of training programmes. It seems desirable for students to view leadership as part of their identity. In order for this to occur, it is necessary to provide opportunities for student leaders to relate to others in a way that will encourage this to develop. This can be part of student leadership training. Schools can involve staff, family and outside sources in training programmes. It would also be beneficial for students to be encouraged to reflect on their leadership experiences, to evaluate and discuss what works well in their leadership situation. 


\subsection{The School Environment}

\subsubsection{Creating a supportive school}

Leadership identity formation relies on students being supported (Komives, et al., 2006). To develop effective leaders and training it is important for schools to create and sustain a school environment that values student leadership. This idea matches research on school leadership where negotiation and power sharing are encouraged (Busher, 2006; Mitra, 2005). Mitra writes positively of schools that allow student groups to contribute to school reform and share decision-making.

A sense of frustration was voiced by some student leaders when they were given a position or a title that signified leadership, but felt that they were not given chances or contexts to exercise that leadership. For example, one student explained "we don't really have anything to do it's just 'here you're a prefect walk around the school like you're a role model" "(Connor, 17, School A). It is possible that giving power to student leaders is a difficult thing for schools that have a number of stakeholders seeking to control a school's direction and daily activities. In this scenario, it may be possible for student leaders to be encouraged to lead cooperatively with staff and the wider school community so that their opportunities for leadership become tied to wider school goals. Research based on school leaders supports this idea when setting direction (Davies, 2005) and encourages power sharing (Cartwright, 2005). Davies' suggestion that everyone should be involved in goal setting and planning for the future relies on student input. Mitra's (2005) research into the student voice suggests a good example of distributed leadership is when students and teachers work together.

It is also important for schools to decide on the role of teachers who are involved in student leadership training. Mitra (2005) advocates for teachers to take on the role of supporter. In my case study schools, however, teachers work effectively as instructors, guides and supporters. The role of the teacher is likely to be defined by the school culture and replicate the type of student/staff relationships in the wider school community. Teachers can also act as role models for students, which is one of the key ways that students can learn to lead (Martinek, et al., 2006). Komives et al. (2006) explain that because students may make a crucial transition from Leader Identified (Stage 3) to Leadership Differentiated (Stage 4) during their senior secondary school years, staff need to provide them with the right combination of challenge and support. They go on to encourage 
educators to create environmental conditions that assist learning and support student leaders.

Research shows that the student voice needs to be heard and acted upon for student leaders to feel that they have an active part in creating the school's priorities and practice. For example, one student felt valued because:

when we go to the council meetings they're actually taking on what we're saying with the principal and ... recommending some of the ideas so I think there's no point having student leaders if they're not actually going to get heard (Rebecca, 13, School C).

Students from School A appreciate the opportunities they have to meet with senior management and to be involved in goal setting. Students from School B see student leaders as an avenue for the student body to share ideas with the principal. In School C, the fact that the principal attends school council meetings helps students feel that, through their class and year level representatives, they have a direct line to management and therefore have a say in the running of the school. An environment where the student voice is used is likely to encourage student leadership.

Leadership opportunities at all year levels provide openings for students to form their leadership identity and learn leadership at a young age. Student leaders appreciate learning from previous student leaders, which could be done in an informal way through observation, a semi-formal way through mentoring and encouragement, or in a formal way where junior students are included in leadership teams. Students in School A who had been encouraged by previous leaders felt more empowered and capable of leading when they were in Year 13. Students in School B appreciated being on the student executive as Year 11 students so they had more ideas about what to do when they were in Year 13. This reflects key ideas that leadership involves learning as part of a community (Lambert, 2003). If the environment and systems encourage student leadership, students can learn how to work with others and how to lead in a way that others respond to while they are progressing through secondary school.

\subsubsection{Focusing on the situation}

As previously mentioned, it is essential for student leaders to know the people and the place where they will practise leadership. Training should include familiarisation with the 
school environment and the people leaders will interact with. Understanding can begin in this area through involvement and participation. Active involvement in the classroom and extracurricular activities will help students understand their school. Students at School A valued the time they had spent in various teams and groups as it gave them institutional knowledge of staff and systems before they were appointed to a formal leadership position. This knowledge gave them confidence and skills to take into their leadership practice. Similar results were found in research into peer education, which concluded that success depends on the situation (Shiner, 1999). Leaders in the peer education teams needed to know the location and needs of the people involved. Whitehead (2009) also advocates for leadership programmes that are customised to each school. In all New Zealand secondary schools, student leaders represent the student body. It is therefore essential that they understand the student body's experience.

Effective training occurs in Schools A and C when students are formally trained by staff members. In all three schools, student leaders are also supported by staff members who take an interest in their leadership experiences. This may be through being a form teacher, mentor or supervisor. Past leaders may also be utilised in training because they are familiar with the leadership situation through recent experience, and students value their knowledge and expertise.

\subsection{Students as Role Models}

Role modelling is an aspect of leadership represented to varying degrees in all three schools. Schools can prepare students for this form of leadership.

The prefects at School A are very aware of the school's expectation of them to be a positive role model for the rest of the students coming through the school, and especially for younger students to look up to. Those who commented positively about being a role model described the necessary qualities as being approachable, helpful, friendly, someone who is easy to get along with and someone who sets a good example. The approaches a role model was considered to need in their interactions with others included knowing when to take control and when to step back, as well as getting everyone to help. Students explained that a role model has to have integrity so that their words match their actions, which confirmed a comment from the teacher in charge of student leaders at School A, who said that teenage boys hate hypocrisy. The students at School A who were frustrated at the expectation for them to be role models saw it as not being enough. There was a sense 
of dissatisfaction at there not being much for a role model to do except, "go round looking good" (Connor, 17, School B).

Students in School B were less likely than students in School A to describe themselves as role models. One of the head students did recognise that the job of a head student was to be a good role model and example which she defined as "someone that someone looks up to" (Aisha, 17, School B). A good leader was also defined as someone "who people look up to .. as a role model ... who can be respected ... and followed" (Elise, 17, School B).

Participants from the student body also considered student leaders to be role models who should lead by example.

Unlike Schools A and B where role modelling was mentioned by student leaders as one of their roles, none of the student leaders at School C referred to themselves as role models. It was only mentioned twice by students from the student body. One suggested that the way student leaders show leadership was by being role models to other students. The other said that peer support leaders were role models to Year 9 students. I assumed this lack of focus on role modelling was because the school promoted individual expression and therefore to encourage the student body to model themselves on the student leaders may be seen as an attempt to stifle individuality. When I suggested this to the principal during an early feedback session, he disagreed and thought it could be because the student leaders did not have a high profile in the school. He thought that there was the potential for them to be seen as role models because they could take some responsibility for student behaviour and attitudes. This idea matches the findings in recent research by Lavery (2006), which concludes that student leaders have a positive influence on students' attitudes and actions. It also supports recent research, which concluded that student leaders' commitment to academic achievement is likely to be accepted and followed by the rest of the school (Smith \& Piele, 2006).

Role modelling is closely tied to leadership identity development. It is an aspect of leadership that requires dedication as it is primarily about a person's attitude and actions. It is not defined in job descriptions, but is often linked to the school's values and expectations as well as to general ideas about interpersonal relationships. Leadership training should include a focus on how students can make the most of the opportunity to be a role model. It can show students how to act as role models and to cope with the variety of implications in this leadership role. 


\subsection{Leading from the Middle}

\subsubsection{Reinforcing leading from the middle}

A recurring theme in the interviews was that leading from the middle is the type of leadership students feel most comfortable with. Leading from the middle means being a leader who is part of a group, involved in the same activities and working towards the same goals. It is often referred to as intrapersonal leadership. In order to recognise all types of leadership, training can outline leading from the front, leading from behind and leading from the middle. However, emphasis should be placed on what is involved in leading from the middle because students like to be part of a group. This finding matches suggestions by Dempster and Lazzio (2007) that student leaders like to work as a team, sharing responsibilities and tasks. Leadership becomes a group effort. On a wider scale, they are part of the group of all students at the school and become their voice when exercising leadership. On a smaller scale, they might lead from within their team. Collaboration has also been identified as a highly valued leadership quality (Komives, et al., 2006) that can be taught when students train as a team. It is important that students learn how to maintain relationships that uphold group goals because this is recognised as a valuable quality in young leaders (Roach, et al., 1999). Students can find it difficult to lead their peers as they may experience a conflict of interest between what the school wants and what their friends want. Ideas and strategies for coping with this conflict could be useful.

\subsubsection{Focus on building leadership teams}

When designing leadership programmes, schools should prioritise leading as part of a team and team building exercises. Students see team leadership as a chance to work together utilising everyone's strengths. Schools may have established leadership teams like council, executive and prefects that change each year. When students are elected or selected to be part of one of these teams they may not know each other. The initial training sessions are therefore vital for the team to get to know each other and develop trust.

As students transit out of the Leader Identified (Stage 3) in LID, they recognise that a leader can not do everything by themselves. This recognition is a key transition event. Students develop a new awareness that people in groups work interdependently (Komives, et al., 2006). Practising processes that include consultation and collaboration during training would encourage student leaders to lead as a team in the future. This idea is supported in research by Roach et al. (1999), which concludes that young people see 
leadership as a group activity and that students should therefore be trained to work as a group. Research findings also suggest that staff can design group projects that intentionally teach groups process that work well (Komives, et al., 2006).

Team work is seen as a way of allowing leaders to work as a group and respond individually so that they are able to experience support and autonomy in their leadership role. Good leaders are seen as having a dual interest in helping the situation and working out how to get everyone involved to help out. This results in the situation improving and the team feeling successful. Training students to consider the situation as well as the people they are working alongside could be an effective strategy. Students see a key function of leadership as bringing everyone together. This matches suggestions from research into peer support programmes in the United Kingdom (Cartwright, 2005). Cartwright emphasises the benefits of learning to work with others as it encourages personal development.

Training sessions in all three case study schools had a strong focus on building the capabilities of the leaders as a team. The third prefect training session at School A began with an activity that reminded the prefects that the most important thing for them to consider was not individual success but team achievement. This became a key idea throughout the training session as prefects focused on what they could do together to improve their leadership practice. Even though the house leaders at School B could be seen as competing against each other in the house competition, they are also working together as a team. In the meetings they have with a teacher prior to a house event they plan and strategise as a group. This seems to make them feel a sense of consistency and togetherness. The peer mediation training at School $\mathrm{C}$ has a strong focus on training as a team and working together. At the training:

the first goal was mainly to make sure that we're a team and can all work together cos with mediations it's always done with two students so you need to be able to work well with the other student and so we'd go away and we'd do all these team building exercises to learn about each other and we do the ... values session just to find out about everyone's different values in life and just to see if we can find common ground there (Blake, 16, School C). 
This shows that the training is based on recognising differences within the group and finding commonalities that will lead to successful group work in their leadership routines. This is important for the leadership situation where students need to work together effectively when running potentially stressful mediations.

Schools may have group or team situations for student leaders to operate in. In order for a leadership team to be successful, team building needs to occur and ways of working together as a team need to be learnt and practised. This can be a useful component of leadership training programmes.

\subsection{Learning by Doing}

\subsubsection{Focus on practical and include theoretical}

Schools will benefit from systematically preparing students for leadership with a wellplanned leadership programme. Bush (2009), who writes on leadership development, confirms that this is more useful than chance experiences. Karcher (2008), in his work on mentoring, confirms this and goes as far as to say that a highly-structured programme is most beneficial for mentors and mentees.

It is worthwhile considering how schools can include both practical and theoretical components in their programmes. When students reflected on the type of training they enjoyed, the sessions that focused on practical tasks rated highly. Students enjoyed handson activities when learning about leadership. This included small group brainstorms, playing games, giving a group presentation and running mock mediations. Positive comments were made by students regarding training that included active learning. The peer support training in Schools A and C and the peer mediation training in School C are based around students doing the type of activity they will be required to do when leading. Students considered that they learnt a lot when given a context to be a role model. They also developed as leaders when given a group or team to lead as part of their training. This kind of leadership training enables students to develop greater confidence.

There were also positive comments by students about sessions that included a lecture component where they were led to consider new ideas or had old ideas reinforced. Teaching the language of leadership allows students to consider how they lead and see their practice in the wider context of leadership theory. Komives et al. (2006) sees this as an aspect schools can use as they guide students through Leadership Differentiated (Stage 
4) of LID where students see leadership as a process that could come from anyone in the group. Education through leadership training programmes is also seen by Martinek et al. (2006) as a useful aspect of leadership development, along with learning through trial and error and with role models. This study's findings suggest that theoretical type of training needs to come second to practical experiences. Students need to experience leadership to be able to talk about it, evaluate it and reflect on it. In which case, it seems logical for leadership training to focus on practical experiences and include theory when necessary.

\subsubsection{Promote learning by doing}

If you want to teach them how to be a leader don't do it just talking to them ... make them experience it cos that's the only way you're going to learn ... I mean you can write down all you want about leadership but ... if you've got a group of people and you have to lead them as such and all you've done is written it down you won't know what to do ... you won't be able to relate to them and say here listen to me... but if they don't listen to you then you're screwed pretty much ... so it's experiencing how to be a leader not just writing down and listening to how to be a leader (Luke, 17, School B).

The strongest theme in all three schools was the importance of learning leadership by leading. The best training schools can give students is to put them in leadership situations. This reinforces the importance of creating and developing a school environment that encourages leadership. Students feel that they learn the most about leadership when they are in situations that they can show leadership. This supports Neigel's (2006) suggestion that students can be involved in school development projects by choosing a problem, researching, investigating and recommending changes. The students learn about leadership through this process.

Research also suggests that young people value wise spontaneity in leaders (Roach, et al., 1999), which is probably an approach that develops through experience. Students learn how to read and respond to situations as they develop. This matches one of the suggestions based on research by Martinek et al. (2006) that trial and error is a key aspect of leadership development. Related to leadership identity development, Komives et al. (2006) also see meaningful involvement as a key developmental influence that schools can integrate into leadership training programmes. Students in Posner's (2009) longitudinal study shared the same idea that experiential learning was more useful than being taught about leadership. 
Students in the three case study schools explained that they had been trained for leadership through their classroom and extra-curricular activities. In the classroom they had learnt leadership through group activities. They were able to organise their classmates to solve problems and work together. In extracurricular activities they had coached younger students, been mentored by older students and given areas of responsibility. They saw these situations as building their leadership skills and knowledge.

"On-the-job" training is perceived to be the most effective by students and can be complemented with support by staff while students lead. Staff may be appointed as a teacher in charge to whom student leaders can go to for help and advice. Guidance and mentoring by staff or older students while doing leadership allows students to grow through this method of training.

Students appreciated interacting with the student body during their formal leadership training sessions. This confirms suggestions that training needs to form a bridge into a student's experience in order to be effective (Bush, 2009), and that leadership training should have practical applications (Whitehead, 2009). The student body can be used to provide authentic contexts for leadership training. The prefects at School A enjoyed the session involving Year 8 students, and the student at School B who helped run the CACTUS course for school students saw the experience as effective training. He described this experience:

I was actually leading a group of kids at the same time just being a peer with them as well and like try and help them through things and the same with the ACE course so ... that's what I found best was learning in the field (Luke, 17, School B).

Students' confidence grows through experience. They are also able to develop the ability to look outside themselves and learn to work with people.

I mean the more you work with people the more you're gonna ... find out what works and what doesn't and you're gonna start recognising personality traits that you ... need to deal with in different ways and that kind of thing (Genevieve, 16, School C). 
The BOT student rep at School C explained that attending meetings and asking questions was invaluable. Students who had been part of the student exec in School B learnt what to do in future years through observing others.

Schools can also look to the wider community for contexts to learn leadership by doing. Most of the leadership contexts in my case study schools were school-based. However, as suggested by Lavery (2008), schools can assist students in their personal growth by encouraging them into community service. This could be a valuable and practical situation to learn about leadership.

Students perceive they learn the most through experience. Therefore, experiential learning equips students for leadership. They feel good about showing leadership and also contributing to the school.

\subsection{Summary}

The research findings show that effective student leadership training can occur in two key areas that are interdependent. Firstly, schools can foster leadership identity formation by developing a supportive school environment. This involves distributed leadership for students, avenues for the student voice in decision-making, early and ongoing opportunities to show leadership and leading students to understand their situation. Secondly, schools can create a formal leadership training programme for students. Some elements of the training programme may include role modelling, leading from the middle and building leadership teams. A synthesis of key ideas from my results and recent literature shows that students learn by doing and should be given opportunities to lead as part of their formal leadership training programme.

Figure 5-2 shows this model of leadership training where the starting point is a supportive school environment. This is followed by programme design. Learning by doing is the main goal. 
Supportive

School

Environment

- inclusive

- student voice

- partnerships
Programme Design

- at all levels

- school based

- role modelling

- leading as a team
Learning by Doing

Figure 5-2: Model of Leadership Training. 


\section{Chapter 6: Conclusion}

\subsection{Summary of Main Research Findings}

This study was based on investigating what constitutes effective student leadership training in New Zealand secondary schools. The aim was to discover some suggestions for schools to implement in the design and delivery of training programmes. Primarily through semistructured interviews with teachers, student leaders and members of the student body in three schools, it was possible to learn about perceptions of leadership and training.

The following concluding comments relate to the participant schools. It is possible that these comments could apply to a number of other schools too, depending on their size, staffing and school culture. Student leaders show leadership in response to roles they may be given and their school experiences. Their leadership is defined by their school's expectations and requirements, as well as by the training they receive. Schools offer students a variety of training for leadership. Student leaders perceive training to be both formal and informal. Informal training occurs through experiences inside and outside school where students may be encouraged or directed to show leadership in a team or a specific context. This builds their confidence and skills. Formal training occurs in a range of ways through prepared programmes. These may include daily support from a teacher during form time, students being sent on external courses, consultants delivering one-off sessions in the school and staff delivering training based on school programmes like peer support.

Students in all three schools are practising aspects of distributed leadership. To varying degrees, students already operate in leadership teams that enable them to lead as a group. Student leaders are also aware of the impact their situation has on their leadership practice, recognising the need to respond to the environment as they lead. Leadership identity development is obvious as students learn to see themselves as leaders wherever they are. This is also displayed when they recognise that part of their role is to empower others so that leadership comes from within a group rather than being imposed on it.

My conclusions on effective training focus on two areas, the school environment and training programmes. A school that effectively trains student leaders has an inclusive culture where the student voice is heard and acted upon. In these schools, management 
partners with students in decision-making and in defining what student leadership involves. Opportunities and formal leadership training programmes occur at each year level and are ongoing. Effective training programmes are school-based, using the resources of staff and previous student leaders. They provide training on role modelling and leading as a team. Programmes must also be designed to equip students for leadership in their particular school context as well as preparing students for a lifetime of leadership. Finally, the key to effective student leadership training is to provide opportunities for student leaders to learn by doing.

\subsection{Implications for Schools}

These main conclusions have implications for the way schools train student leaders. Schools may wish to consider their student leadership structure, the conduciveness of their school environment for developing student leadership and the formal training programmes they have for student leaders.

\subsubsection{Student Leadership Structure}

As is the case in School A and School B, student leadership positions are mainly given to students in their final year of school. If schools recognise that leadership can be developed throughout a student's time at school, they may wish to introduce leadership opportunities at each level. This will also enable aspects of distributed leadership to develop as the range of those doing leadership will increase. Schools may also consider whether they tie leadership to roles or positions. Schools can facilitate leadership identity development by recognising that some students see leadership as a position and others see leadership as an aspect of who they are. Schools can assist with this key transition in thinking that may occur in students as they move through secondary school. This may involve providing both leadership roles with expectations attached and freedom for students to create and define leadership for themselves.

\subsubsection{School Environment}

To create a school environment that trains student leaders, schools may wish to consider how they respond to the student voice. Students will be further equipped and enabled to show leadership if they can see avenues and opportunities to contribute to the life of the school. Leadership may be fostered in the early years of high school as schools work from 
the premise that leadership can be learnt. Students in Year 9 and 10 can work alongside Year 11-13 students to learn about leadership.

\subsubsection{Training Programmes}

The research findings, although based on a limited sample, conclude that it is preferable for schools to design training programmes to suit their school. The demographic, culture and needs of each school vary and student leaders should be prepared to respond appropriately to the student body. Student leaders feel confident when they are able to contribute effectively which can stem from a knowledge and understanding of the world immediately around them. Members of the student body appreciate student leaders that understand and respond to their situation. Regular and relevant training programmes can support students as they show leadership. Schools should consider their own resources. Student leaders respect and respond well to people they know and trust. Therefore, the principal, staff and previous leaders can be used to deliver components of the training programme.

The design of a training programme can be based on practical activities and include theory. Schools should consider using and explicitly teaching the model of distributed leadership so that students see leadership as a shared activity that is influenced by the situation. Teaching the language of leadership and encouraging reflection will enable students to further develop their leadership identity. A large proportion of any training programme should be practical to facilitate experiential learning. This may involve team building exercises, group activities, role-play and situations where participants can display leadership. Learning to lead involves providing authentic contexts for students to show leadership.

\subsection{Limitations of this Study}

As previously stated, this study has limitations around the research design, research process and the scope of the project. By doing a multiple-case study I attempted to allow for greater generalisation of my findings, hoping that, if there were common elements in all three schools, these could be applied to any type of school. Three is still a small number of schools to study and 38, a small number of participants. To allow for greater generalisation, a wider variety of schools should be studied.

The research design was based on three methods of data collection, however, during the research process, it was only possible to observe one training session in one school. Time 
constraints prevented more being done. This meant that, for the case study research, reliance was placed primarily on the data from semi-structured interviews. Although unable to get data through a range of methods, it was possible to gain data from a range of sources by speaking with teachers, leaders and the student body. This allowed me to focus on the framework of distributed leadership.

My definition of effective training is when schools equip students for leadership and enable students to contribute to the school community. Equipping was primarily assessed through the perception of the student leaders. The aim was to see if they felt confident and capable as a leader. Enabling was also assessed through participants talking about their actions and the impact of their actions on others. A programme evaluation was not completed based on assessing outcomes as the scope for the research included wider ideas about leadership and training. Although this may be seen as a limitation, this approach made it possible to see training as it was interpreted by the participants and in a holistic manner. Therefore, the research has become less about programmes and more about schools' overall approaches to leadership training. This focus may have wider implications for schools who are interested in leadership development.

\subsection{Suggestions for Further Research}

There were a number of issues that arose during the research that warrant further investigation.

\subsubsection{Follow up research}

It would be possible to conduct follow-up research to judge the authenticity of the implications for schools that stem from the research findings. A research project could be conducted in a school that implements these findings to see if they are effective in enhancing student leadership training.

\subsubsection{What is leadership?}

I mainly focused on student leadership training, but many ideas and questions surfaced around how students view leadership. A phenomenological study could be conducted in an attempt to define the essence of what leadership means to secondary school students, which could assist the development of relevant approaches to leadership training. 


\subsubsection{Gender and leadership}

This was an area that I investigated when completing the literature review, but I was unable to incorporate it into the research design. It would be interesting to note if schools recognise and modify their leadership training programmes according to the gender of their students. Traditional male leadership models differ most with distributed leadership theory as they tend to focus on separation between leaders and followers, competition for rewards, productivity and structured relationships with others. By contrast, female leadership models are collective, including a participatory style and with an emphasis on the empowerment of others (Kezar, 2000). It would be interesting to see if student leadership training programmes in New Zealand secondary schools conform to, or challenge, these models.

\subsubsection{Māori leadership}

Leadership training may need to be responsive to the cultural background of student leaders. Writing that stems from conversations with young Māori recognises the contribution they can make. Tipene-Clark (2005) emphasises that Māori young people need opportunities to share their ideas on needs and solutions. She acknowledges that rangatahi (youth) are future leaders and to be equipped for the task they need to be:

educated, politically astute, firmly grounded in their Māori cultural base, sophisticated, strong and committed to their Iwi and their people. They must be able to withstand whatever difficulties come before them. They must be able to accept criticism both from their own people and from Pākehā society and know how to deal with it effectively (Tipene-Clark, 2005, p. 42).

A study could be conducted to see if these aspects are acknowledged in the training of Māori students. It has also been identified that an adult mentor is especially important for minority students (Komives, et al., 2005). Do New Zealand secondary schools provide a place for Māori students to explain ideas to their peers and others of influence in the school community? Do schools run training programmes that are based on Māori values of leadership?

\subsubsection{Leadership by non-conventional students}

Another area that drew my personal interest was the leadership potential of nonconventional students. I was interested in seeing what types of students were selected as 
leaders, however, the scope of this study did not allow analysis of whether student leaders had conventional or non-conventional leanings (conventional refers to students who comply with the school's expectations, non-conventional refers to students who contradict or challenge the school's expectations). My perception was that the students who were in leadership positions were mainly conventional. I am interested in seeing how schools can harness the leadership potential of non-conventional students. Although this would pose a range of ethical and logistical issues, I would be interested in conducting action research in this area. The research design would need to be carefully planned because I suspect that when non-conventional students partner with teachers their peer group status is threatened. If students who have leadership skills but do not conform to their school's expectations can be involved in shaping the school environment, there may be learning and social benefits. This idea is worth investigating and inspires me to continue my research journey.

\subsection{Concluding Comments}

Student leaders have the potential to transform a school and are willing to lead in many ways. Leadership training is multi-faceted and based on allowing students to experience leadership in a supportive and challenging environment. Although school resources are stretched, teachers in charge of student leaders are working to help students realise their potential. Partnerships between the school community and student leaders can lead to effective training in leadership. I encourage schools to get student input into the design of student leadership training programmes and continually evaluate what they do. Schools can thereby be responsive to changing ideas about student leadership. When schools provide a range of training opportunities and allow student leaders the freedom to lead, the possibilities are endless. 


\section{References}

Alton-Lee, A. (2003). Quality teaching for diverse students in school: Best evidence synthesis iteration (BES). Wellington Ministry of Education Education Counts.

Berg, B. L. (2007). Qualitative research methods for the social sciences (6th ed.). Boston: Pearson.

Big Brothers Big Sisters. (n.d). Retrieved September 12, 2010, 2010, from http://www.bbbs.org/site/c.9iILI3NGKhK6F/b.5962335/k.BE16/Home.htm

Bishop, S. (2003). The development of peer support in secondary schools. Pastoral Care in Education: An International Journal of Personal, Social and Emotional Development, 21(2), 27 - 34.

Bogdan, R., \& Bilken, S. (1997). Qualitative research for education. Boston: Allyn \& Bacon.

Boone, D. A., \& Taylor, N. (2007). Leadership skills: Where are they being taught? Techniques: Connection Education and Careers, 82(8), 48-50.

Brown, K. (2003). Changing the language of thinking. Educare News, 138; 30-31.

Bush, T. (2009). Leadership development and school improvement: Contemporary issues in leadership development. Educational Review, 61(4), 375-389.

Busher, H. (2006). Understanding educational leadership: People, power and culture. Maidenhead: Open University Press.

Cartwright, N. (2005). Setting up and sustaining peer support systems in a range of schools over 20 years. Pastoral Care in Education: An International Journal of Personal, Social and Emotional Development, 23(2), 45-50.

Cohen, L., Manion, L., \& Morrison, K. (2000). Research methods in education (5th ed.). London: RoutledgeFalmer.

Court, M. (2004). Talking back to new public management versions of accountability in education: A co-principalship's practices of mutual responsibility

Educational Management and Administration Leadership, 32(2), 171-194. 
Creswell, J. W. (2008). Educational research: planning, conducting and evaluating quantitative and qualitative research. Upper Saddle River, N.J: Pearson/Merrill Prentice Hall.

Davies, B. (Ed.). (2005). The essentials of school leadership. London: Paul Chapman and Corwin Press.

Dempster, N., \& Lazzio, A. (2007). Student leadership. Australian Journal of Education, 51(3), 276-285.

Denzin, N. K., \& Lincoln, Y. S. (2005). The Sage handbook of qualitative research. Thousand Oaks: Sage.

Freeborn, S. (2000). Schools captains: School and community expectations. Practising Administrator, 22 (4), 18-19, 44.

Gronn, P. (2000). Distributed properties. A new architecture for leadership. Educational Management and Administration, 28, 317-338.

Gronn, P. (2002a). Distributed leadership. In K. Leithwood \& P. Hallinger (Eds.), Second international handbook of educational leadership and administration part two (Vol. 8 pp.653-696). Dordrecht: Kluwer.

Gronn, P. (2002b). Distributed leadership as a unit of analysis. The Leadership Quarterly, $13(4), 423-451$.

Gronn, P. (2003a). New work of educational leaders: Changing leadership practice in an era of school reform. London: Sage.

Gronn, P. (2003b). Without leadership. In B. Davies \& J. West-Burnham (Eds.), Handbook of educational leadership and management (pp. 60-66). London: Pearson Education.

Halogen Foundation. (n.d). Retrieved August 17, 2010, from http://www.halogenfoundation.org/about.asp

Harris, A. (2005). Distributed leadership. In B. Davies (Ed.), The essentials of school leadership (pp. 160-173). London: Paul Chapman and Corwin Press.

Harris, A. (2008). Distributed leadership: According to the evidence. Journal of Educational Administration, 46 (2), 172-188. 
Houlston, C., Smith, P. K., \& Jessel, J. (2009). Investigating the extent and use of peer support initiatives in English schools. Educational Psychology, 29(3), 325-344.

Hynes, K. (2006). 20 years on...Evaluation of the peer support programme in New Zealand secondary schools. Retrieved August 2, 2010, from http://www.peersupport.org.nz/Forms/K\%20Hynes\%20Report.pdf

Iarossi, G. (2006). The power of survey design. A user's guide for managing surveys, interpreting results and influencing respondents. Washington DC: The World Bank.

Karcher, M. J. (2008). The cross-age mentoring program: A developmental intervention for promoting students' connectedness across grade levels. Professional School Counselling, 12(2), 137-143.

Kezar, A. (2000). Expanding our understanding of student leadership development: A study exploring gender and ethnic identity. Journal of College Student Development, 41(1), 55-69.

Komives, S. R., Mainella, F. C., Longerbeam, S. D., Osteen, L., \& Owen, J. E. (2006). A leadership identity development model: Applications from grounded theory. Journal of College Student Development, 47(4), 401-418.

Komives, S. R., Owen, J. E., Longerbeam, S. D., Mainella, F. C., \& Osteen, L. (2005). Developing a leadership identity: A grounded theory. Journal of College Student Development, 46(6), 593-611.

Kvale, S. (1996). An introduction to qualitative research interviewing. Thousand Oaks: Sage.

Lambert, L. (2003). Leadership capacity. Alexandria: Association for Supervision and Curriculum Development.

Lavery, S. (2006). Student leaders: So many reasons to bother. Principal Matters 69 (Summer 2006) 27-28.

Lavery, S. (2008). Developing student leadership through service-learning. Journal of Catholic School Studies, 80(2), 5-12.

Lee, P. (2006). Building and leading the learning school. Principal Matters, 70 (Autumn 2006) 10-13. 
Lines, A., \& Gallasch, G. (2008). The rite way. Teacher, (February, 2008) 28-30.

Martinek, T., Schillling, T., \& Hellison, D. (2006). The development of compassionate and caring leadership among adolescents. Physical Education and Sport Pedagogy, 11(2), 141-157.

McGregor, J. (2007). Recognising student leadership: Schools and networks as sites of opportunity. Improving Schools, 10, 86-101.

Miles, M. B., \& Huberman, A. M. (1984). Qualitative data analysis: A sourcebook of new methods. Beverly Hills: Sage.

Ministry of Education. (n.d). Retrieved October 29, 2009, from http://www.minedu.govt.nz/

Ministry of Education. (n.d). Retrieved December 1, 2010, from http://www.minedu.govt.nz/NZEducation/EducationPolicies/Schools/SchoolOperat ions/Resourcing/OperationalFunding/Deciles/DecilesInformation.aspx

Ministry of Education. (2007). The New Zealand Curriculum. Wellington: Learning Media Ltd.

Mitchell, J. C. (2000). Case and situation analysis. In R. Gromm, M. Hammersley \& P. Foster (Eds.), Case Study Method (pp. 165-186). London: Sage.

Mitra, D. L. (2005). Adults Advising Youth: Leading While Getting Out of the Way. Educational Administration Quarterly, 41 (3), 520-553.

Moore, G. (1999). Leadership matters. Independence, 24(1), 18-19.

Neigel, K. (2006). Building leadership capacity in students. Principal Leadership, 7(4), 20 24.

New Zealand. Department of Education. (1988). Tomorrow's schools: The reform of education administration in New Zealand. Wellington: Dept. of Education.

NZCER. (n.d). Retrieved October 29, 2009, from http://www.nzcer.org.nz/

On the Edge - about us. (n.d). Retrieved October 4, 2010, from http://www.ote.org.nz/about-us

Patton, M. Q. (2002). Qualitative research and evaluation methods (3rd ed.). Thousand Oaks: Sage. 
Posner, B. (2009). A longitudinal study examining changes in students leadership behaviour. Journal of College Student Development, 50 (5), 551-563.

Punch, K. (1998). Introduction to social research: Quantitative and qualitative approaches. Thousand Oaks: Sage.

Punch, K. (2005). Introduction to social research: Quantative and qualitative approaches. Thousand Oaks: Sage.

Ritter, L. A. (2007). Conducting online surveys. Thousand Oaks: Sage Publications

Roach, A. A., Wyman, L. T., Brookes, H., Chavez, C., Heath, S. B., \& Valdes, G. (1999). Leadership giftedness: Models revisited. Gifted Child Quarterly, 43(1), 13-24.

Robinson, V., Hohepa, M., \& Lloyd, C. (2009). School leadership and student outcomes: Identifying what works and why. Wellington: Ministry of Education Education Counts.

School A website. (2010). Retrieved November 17, 2010

School B website. (2010). Retrieved November 17, 2010

School C website. (2010). Retrieved November 17, 2010

Shiner, M. (1999). Defining peer education. Journal of Adolescence, 22, 555-566.

Smith, S. C., \& Piele, P. K. (2006). School leadership: Handbook for excellence in student learning. Thousand Oaks: Corwin Press.

SPARC growing leaders. (n.d). Retrieved October 13, 2009, from http://www.sparc.org.nz/education/growing-leaders/growing-leaders-resources

Spillane, J. P. (2006). Distributed leadership. San Francisco: Jossey-Bass.

The Spirit of Adventure Trust. (n.d). Retrieved September 2, 2010, from http://www.spiritofadventure.org.nz/

Tasker, G. (2004). Making meaning: Making a difference. Retrieved October 24, 2009, from http://www.tki.org.nz/r/health/cia/make_meaning/index_e.php

Timperley, H. S. (2005). Distributed leadership: Developing theory from practice. Journal of Curriculum Studies, 37(4), 395-420.

Tipene-Clark, R. (2005). He korero o nga rangatahi. Childrenz Issues, 9 (2), 37-42.

Te Kete Ipurangi. (n.d). Retrieved October 29, 2009, from http://www.tki.org.nz/ 
Walker, S. A., \& Avis, M. (1999). Common reasons why peer education fails. Journal of Adolescence, 22, 573-577.

Whitehead, G. (2009). Adolescent leadership development. Building a case for an authenticity framework. Educational Management, Administration and Leadership, $37(6), 847-872$.

Woolnough, A. (2008). The New Zealand Police on line magazine. Retrieved September 17, 2010, from http://www.inbox.net.nz/tenone/Nov08Cactus.htm

Yin, R. K. (2003). Case study research design and methods (3rd ed.). Thousand Oaks: Sage.

Youth Council. (n.d). Retrieved October 4, 2010, from http://www.wellington.govt.nz/services/youth/youthcouncil.html 


\section{Appendices}

\section{Appendix A: New Zealand Secondary School System}

\section{Types of Schools}

Single Sex - one gender

Co-educational - both males and females

\section{Years}

Years 9-13

Students usually begin Year 9 when aged 13 and leave Year 13 aged 18.

\section{School Year}

Divided into 4 terms

Each term 10 weeks long

Usually beginning in the last week of January

\section{Decile}

Schools have a decile rating based on the average family or whanau socio-economic background of its students. Decile 1 schools are the $10 \%$ of schools with the highest proportion of students from low socio-economic backgrounds. Decile 10 schools are the $10 \%$ of schools with lowest proportion of these students. ("Ministry of Education," 2010). High decile refers to schools rated 8-10 and low decile schools are rated 1-4. 


\section{Appendix B: Interview Questions}

\section{Teacher Interview Questions}

\begin{tabular}{|c|c|}
\hline Questions & Notes for Protocol \\
\hline $\begin{array}{l}\text { What is your role in connection with student leaders at } \\
\text { this school? }\end{array}$ & \begin{tabular}{ll}
\multicolumn{2}{l}{ Probe for } \\
- & Job description \\
- & Tasks \\
- & Formal and Informal jobs \\
- & Relationship
\end{tabular} \\
\hline $\begin{array}{l}\text { What kind of leadership roles do students have at this } \\
\text { school? }\end{array}$ & $\begin{array}{l}\text { Probe for } \\
\text { - } \quad \text { Job titles } \\
\text { - } \quad \text { Formal and informal }\end{array}$ \\
\hline How do you select student leaders? & Clarify process \\
\hline How do you train your leaders? & $\begin{array}{l}\text { Probe for } \\
\text { - } \quad \text { Leadership training programme } \\
\text { - } \quad \text { Support during the year } \\
\text { - } \quad \text { Formal and informal }\end{array}$ \\
\hline What is the purpose of the training you provide? & $\begin{array}{l}\text { Probe for } \\
\text { - Goals, aims } \\
\text { - What } \\
\text { - Links to leadership roles } \\
\text { - Impact on students, community etc } \\
\text { - Individual, team, school }\end{array}$ \\
\hline How effective is the training you provide? & $\begin{array}{l}\text { Probe for } \\
\text { - } \quad \text { Meeting of goals and aims } \\
\text { - } \quad \text { Impact }\end{array}$ \\
\hline $\begin{array}{l}\text { What ideas do you have for future training of student } \\
\text { leaders? }\end{array}$ & $\begin{array}{l}\text { Clarify } \\
\text { - What and why }\end{array}$ \\
\hline $\begin{array}{l}\text { What impact do you think your leaders have on the wider } \\
\text { school community? }\end{array}$ & $\begin{array}{l}\text { Clarify } \\
\text { - } \quad \text { Pos and neg }\end{array}$ \\
\hline What do you think makes an effective student leader? & $\begin{array}{l}\text { Probe } \\
\text { - Personal qualities, skills, attitude }\end{array}$ \\
\hline $\begin{array}{l}\text { What other influences do you think impact on a student's } \\
\text { ability to lead? }\end{array}$ & $\begin{array}{l}\text { Probe } \\
\text { - } \text { Outside school } \\
\text { - } \quad \text { Expectations } \\
\text { - } \text { Group - team }\end{array}$ \\
\hline \multicolumn{2}{|l|}{ Other comments about training } \\
\hline Othe & \\
\hline
\end{tabular}




\section{Student Interview Questions}

\begin{tabular}{|c|c|}
\hline Questions & Notes for Interview Protocol \\
\hline \multicolumn{2}{|l|}{ Age: } \\
\hline \multicolumn{2}{|l|}{ Ethnicity: } \\
\hline What is a good leader? & $\begin{array}{l}\text { Clarify for personal opinion - qualities, } \\
\text { relationships etc }\end{array}$ \\
\hline What does leadership mean to you? & Clarify - "shows leadership" \\
\hline What is your leadership role here? & Clarify tasks \\
\hline How have you been trained for this role? & $\begin{array}{l}\text { Probe for all types of training formal and } \\
\text { informal. } \\
\text { Clarify how training applies to role. }\end{array}$ \\
\hline $\begin{array}{l}\text { What did you think of the training you have } \\
\text { received? }\end{array}$ & $\begin{array}{l}\text { Probe for first impressions and more considered } \\
\text { impressions. } \\
\text { Clarify effectiveness for: } \\
\text { - fulfilling role } \\
\text { - contributing to school community }\end{array}$ \\
\hline $\begin{array}{l}\text { Any further comments on leadership } \\
\text { training }\end{array}$ & Probe for comments on effectiveness \\
\hline $\begin{array}{l}\text { What other factors have contributed to your } \\
\text { experience as a student leader? }\end{array}$ & $\begin{array}{l}\text { Probe for comments on impact of out of school } \\
\text { experiences, esp. regarding aspects of diversity }\end{array}$ \\
\hline $\begin{array}{l}\text { What recommendations would you have for } \\
\text { schools on how they can support and train } \\
\text { student leaders? }\end{array}$ & Probe for school specifics and general comments \\
\hline
\end{tabular}




\section{Student Body Interview Questions}

\begin{tabular}{|c|c|}
\hline Questions & Notes for Interview Protocol \\
\hline \multicolumn{2}{|l|}{ Age: } \\
\hline \multicolumn{2}{|l|}{ Ethnicity: } \\
\hline What is a good leader? & $\begin{array}{l}\text { Clarify for personal opinion } \\
\text { - } \text { Qualities } \\
\text { - relationships etc }\end{array}$ \\
\hline $\begin{array}{l}\text { What kind of student leaders does this } \\
\text { school have? }\end{array}$ & $\begin{aligned} & \text { Probe for } \\
& \text { - } \text { jobs } \\
& \text { - } \text { qualities } \\
& \text { - } \text { roles }\end{aligned}$ \\
\hline $\begin{array}{l}\text { Why do you think this school has } \\
\text { student leaders? }\end{array}$ & $\begin{array}{cl}\text { Clarify } & \\
\text { - } & \text { Purpose } \\
\text { - } & \text { Impact } \\
\text { - } & \text { Benefits } \\
\text { - } & \text { Provisions } \\
\end{array}$ \\
\hline $\begin{array}{l}\text { How do your student leaders show } \\
\text { leadership? }\end{array}$ & Probe for style, actions, relationships etc \\
\hline $\begin{array}{l}\text { What do you think of student leadership } \\
\text { at this school? }\end{array}$ & $\begin{array}{l}\text { Probe for personal opinions of opportunities, } \\
\text { effectiveness, impact on school community, } \\
\text { relationships with staff and students }\end{array}$ \\
\hline $\begin{array}{l}\text { What advice would you give student } \\
\text { leaders? }\end{array}$ & $\begin{array}{l}\text { Probe for school and general } \\
\text { - Clarify } \\
\text { - Actions } \\
\text { - Relationships } \\
\text { - Style } \\
\end{array}$ \\
\hline $\begin{array}{l}\text { How do you think schools should train } \\
\text { student leaders? }\end{array}$ & $\begin{array}{l}\text { Rephrase: what training should schools provide? } \\
\text { What recommendations do you have for schools? } \\
\text { - Clarify } \\
\text { - Content } \\
\text { - Style } \\
\text { - Purpose }\end{array}$ \\
\hline $\begin{array}{l}\text { Other comments about leaders, } \\
\text { leadership and training. }\end{array}$ & \\
\hline Other possible questions & Link to school's aims for leadership and training \\
\hline
\end{tabular}




\section{Appendix C: Participant Selection Process}

A summary of student participants in semi-structured interviews.

Student Leaders

\begin{tabular}{|l|l|l|l|l|}
\hline & School A & School B & School C & Total \\
\hline $\begin{array}{l}\text { Number of student leaders informed of } \\
\text { research and invited to participate }\end{array}$ & 28 & 26 & 12 & 66 \\
\hline $\begin{array}{l}\text { Number of student leaders who } \\
\text { volunteered to take part }\end{array}$ & 14 & 10 & 7 & 31 \\
\hline Number of student leaders interviewed & 9 & 7 & 7 & 23 \\
\hline
\end{tabular}

In School A the student leaders in Year 13 are in the same form class and meet together twice a week. I was able to attend a form time, explain my research and ask for volunteers to participate. I was then able to interview 9 of the 14 that volunteered. The participants were the first 9 with available time.

In School B the Year 13 leaders are also in the same form class and meet together daily. I was able to explain my research, ask all to be involved, record the names of volunteers and interview 7 students.

At School C I was invited to speak to the school council and request volunteers. The school guidance counsellor asked another group of leaders to take part in the research. From these two meetings I was able to get 7 volunteers. 


\section{Student Body}

\begin{tabular}{|l|l|l|l|l|}
\hline & School A & School B & School C & Total \\
\hline $\begin{array}{l}\text { Number of student body } \\
\text { selected, informed of research } \\
\text { and invited to participate }\end{array}$ & 10 & 10 & 10 & 30 \\
\hline $\begin{array}{l}\text { Number of student leaders who } \\
\text { attended information session }\end{array}$ & 3 & 8 & 8 & 19 \\
\hline $\begin{array}{l}\text { Number of student leaders } \\
\text { interviewed }\end{array}$ & 5 & 3 & 4 & 12 \\
\hline
\end{tabular}

At each school I selected 10 students, 2 from each year level working from the premise that I might be able to gain interviews from half the number of students I selected. I called an information meeting, asked for volunteers and arranged interviews with those who consented and gained parental consent if they were under 16.

At School A I was able to interview 5 students. 3 students attended the first meeting, 2 attended the arranged interview, 1 who did not attend contacted me via email to arrange an interview and the teacher in charge chased up 2 others to encourage participation.

At School B I interviewed 3 students. 8 attended the meeting, having been sent for by the school office, 5 arranged interview times and 3 attended, 2 more were asked to participate by the teacher in charge.

At School C I interviewed 4 students. 8 attended the first meeting, 7 arranged interview times and 4 attended. 


\section{Appendix D: Student Leadership Training Survey}

The following questions are about leadership and student leadership training. Please use your own opinions and experiences to answer each question and complete each statement. The survey takes about 15 minutes to complete. Thank you for taking the time to complete this survey.

Q1 A good leader...

\begin{tabular}{|l|c|c|c|c|c|}
\hline & $\begin{array}{c}\text { Strongly } \\
\text { Agree }\end{array}$ & Agree & $\begin{array}{c}\text { Neither } \\
\text { Agree nor } \\
\text { Disagree }\end{array}$ & Disagree & $\begin{array}{c}\text { Strongly } \\
\text { Disagree }\end{array}$ \\
\hline serves others & 0 & 0 & 0 & 0 & 0 \\
resolves tension & 0 & 0 & 0 & 0 & 0 \\
motivates others & 0 & 0 & 0 & 0 & 0 \\
tells people what to do & 0 & 0 & 0 & 0 & 0 \\
makes things happen & 0 & 0 & 0 & 0 & 0 \\
leads by example & 0 & 0 & 0 & 0 & 0 \\
is part of a team & 0 & 0 & 0 & 0 & 0 \\
is a good public speaker & 0 & 0 & 0 & 0 & 0 \\
makes decisions & 0 & 0 & 0 & 0 & 0 \\
is knowledgeable & 0 & 0 & 0 & 0 \\
\hline
\end{tabular}


Q2 Choose the three words (from the list below) that you consider to be the most important characteristics of a good leader.

$\square$ Honest

․ Friendly

口 Organised

口 Popular

口 Confident

口 Non-judgemental

Enthusiastic

口 Trustworthy

Q3 I have taken part in student leadership training.

O Yes

O No

Answer If I have taken part in student leadership training. Yes Is Selected

Q4 Overall, the student leadership training I took part in was effective in helping me to be a good student leader.

Strongly Agree

O Agree

Neither Agree nor Disagree

O Disagree

Strongly Disagree

Answer If I have taken part in student leadership training. Yes Is Selected

Q5 I have been able to put the leadership training I have received into practice this year.

O Strongly Agree

O Agree

Neither Agree nor Disagree

O Disagree

O Strongly Disagree 
Q6 Below is a list of ten suggestions from students on how schools can train student leaders. Please rate each suggestion on how effective you think it would be in developing leaders.

\begin{tabular}{|c|c|c|c|c|c|}
\hline & $\begin{array}{c}\text { Very } \\
\text { Effective }\end{array}$ & Effective & $\begin{array}{c}\text { Neither } \\
\text { Effective nor } \\
\text { Ineffective }\end{array}$ & Ineffective & $\begin{array}{c}\text { Very } \\
\text { Ineffective }\end{array}$ \\
\hline $\begin{array}{l}\text { Provide student leaders } \\
\text { with a teacher as a } \\
\text { mentor }\end{array}$ & 0 & 0 & 0 & 0 & 0 \\
\hline $\begin{array}{l}\text { Get previous student } \\
\text { leaders to give advice }\end{array}$ & 0 & 0 & 0 & 0 & 0 \\
\hline $\begin{array}{l}\text { Send student leaders to } \\
\text { a leadership course }\end{array}$ & 0 & 0 & 0 & O & 0 \\
\hline $\begin{array}{l}\text { Buddy student leaders } \\
\text { with younger students } \\
\text { that need support at } \\
\text { school }\end{array}$ & 0 & 0 & O & 0 & 0 \\
\hline $\begin{array}{l}\text { Have experts come to } \\
\text { school to give student } \\
\text { leaders training sessions }\end{array}$ & 0 & 0 & O & O & 0 \\
\hline $\begin{array}{l}\text { Get the principal to talk } \\
\text { to student leaders }\end{array}$ & 0 & 0 & 0 & 0 & 0 \\
\hline $\begin{array}{l}\text { Give student leaders a } \\
\text { group to lead }\end{array}$ & O & O & O & O & 0 \\
\hline Team building exercises & ○ & ○ & ○ & $\bigcirc$ & 0 \\
\hline $\begin{array}{l}\text { Provide opportunities } \\
\text { for student leaders to } \\
\text { meet with student } \\
\text { leaders from other } \\
\text { schools }\end{array}$ & 0 & 0 & 0 & O & 0 \\
\hline $\begin{array}{l}\text { Have senior student } \\
\text { leaders work on } \\
\text { projects with junior } \\
\text { student leaders }\end{array}$ & 0 & 0 & 0 & 0 & 0 \\
\hline
\end{tabular}


Q7 I am doing a good job as a student leader.

Strongly Agree

O Agree

Neither Agree nor Disagree

O Disagree

O Strongly Disagree

Q8 I have made a positive impact on the school community this year.

Strongly Agree

Agree

Neither Agree nor Disagree

O Disagree

O Strongly Disagree

Q9 I am developing as a leader this year.

O Strongly Agree

O Agree

Neither Agree nor Disagree

D Disagree

Strongly Disagree

Q10 I plan to be in a leadership position in the future.

O Strongly Agree

Agree

Neither Agree nor Disagree

O Disagree

O Strongly Disagree

Q11 What is your gender?

Q12 How old are you?

Q13 What ethnic group(s) do you belong to?

Q14 What school do you go to?

Thank you for completing the survey. You help is much appreciated. 


\section{Appendix E: Summary of Coding Process.}

Initial brainstorm of words and concepts from review of literature:

\begin{tabular}{|c|c|}
\hline How people lead & $\begin{array}{l}\text { - } \text { shared responsibilities } \\
\text { - } \text { practice } \\
\text { - } \text { qualities } \\
\text { - } \text { responsibility } \\
\text { - } \text { structure } \\
\text { - } \text { service } \\
\text { - } \text { compassion } \\
\text { - } \text { caring } \\
\text { - doing leadership } \\
\text { - } \text { skills } \\
\text { - } \text { actions } \\
\text { - boundaries } \\
\text { - potential } \\
\text { - influence } \\
\text { - struggles } \\
\text { - successes } \\
\text { - job } \\
\text { - } \text { process } \\
\text { - style }\end{array}$ \\
\hline Types of Leadership & $\begin{array}{ll}\text { - } & \text { heroic paradigm - the great person } \\
\text { - } & \text { group leadership } \\
\text { - } & \text { relational leadership } \\
\text { - } & \text { strategic leadership } \\
\text { - } & \text { distributed leadership } \\
\text { - } & \text { collective leadership } \\
\text { - } & \text { transformational leadership } \\
\text { - } & \text { token leadership } \\
\text { - } & \text { authentic leadership } \\
\text { - } & \text { servant leadership } \\
\end{array}$ \\
\hline Personal Attributes & $\begin{array}{ll}\text { - } & \text { compassion } \\
\text { - } & \text { service } \\
\text { - } & \text { role modelling } \\
\text { - } & \text { pro-social } \\
\text { - } & \text { anti-social } \\
\end{array}$ \\
\hline Training & $\begin{array}{ll} & \text { equipping } \\
\text { - } & \text { opportunities } \\
\text { - } & \text { aims } \\
\text { - } & \text { engagement } \\
\text { - } & \text { evaluation }\end{array}$ \\
\hline Effective & $\begin{array}{ll}\text { - } & \text { training } \\
\text { - } & \text { leadership }\end{array}$ \\
\hline Positions & $\begin{array}{l}\text { - } \text { peer support } \\
\text { - mentors }\end{array}$ \\
\hline
\end{tabular}




\begin{tabular}{|l|l|}
\hline & $\bullet$ role models \\
\hline Selection & $\bullet \begin{array}{l}\bullet \text { all have leadership potential } \\
\text { Context }\end{array}$ \\
\hline Gender & $\bullet$ community \\
\hline Culture & \\
\hline Student Voice & \\
\hline Relationships & \\
\hline Followers & \\
\hline
\end{tabular}

Second brainstorm for key words from interviews with student leaders and teachers in charge of student leaders.

\begin{tabular}{|c|c|}
\hline Leadership Roles & $\begin{array}{ll}\text { - } & \text { peer mediator } \\
\text { - } & \text { house leader } \\
\text { - } & \text { prefect } \\
\text { - } & \text { peer support leader } \\
\text { - } & \text { student council }\end{array}$ \\
\hline Training & $\begin{array}{ll}\text { - } & \text { learning while doing } \\
\text { - } & \text { preparing for leadership roles } \\
\text { - } & \text { team building } \\
\text { - } & \text { setting goals } \\
\text { - } & \text { encouraging reflection } \\
\text { - } & \text { learning from each other } \\
\text { - } & \text { opportunities to lead }\end{array}$ \\
\hline Ways of leading & $\begin{array}{ll}\text { - } & \text { responsibilities } \\
\text { - } & \text { caring for others } \\
\text { - } & \text { organising people } \\
\text { - } & \text { event management } \\
\text { - } & \text { directing others } \\
\text { - } & \text { looking forward }\end{array}$ \\
\hline $\begin{array}{l}\text { Relationships with } \\
\text { Followers }\end{array}$ & $\begin{array}{l}\text { - leading from behind } \\
\text { - } \text { being available } \\
\text { - } \text { teamwork } \\
\text { - } \text { achieving goals } \\
\text { - } \text { role models } \\
\text { - } \text { priorities others } \\
\text { - } \text { understand the group }\end{array}$ \\
\hline Influences & $\begin{array}{ll}\text { - } & \text { family } \\
\text { - } & \text { work } \\
\text { - } & \text { activities } \\
\text { - } & \text { sport } \\
\end{array}$ \\
\hline
\end{tabular}


The process of producing 12 final codes for thematic analysis:

\begin{tabular}{|c|c|c|c|c|}
\hline Relationships & Relationships & $\begin{array}{l}\text { Positive } \\
\text { Relationships }\end{array}$ & $\begin{array}{l}\text { Positive } \\
\text { Relationships }\end{array}$ & Relationships \\
\hline $\begin{array}{l}\text { Leadership } \\
\text { Positions }\end{array}$ & $\begin{array}{l}\text { Leadership } \\
\text { Positions }\end{array}$ & $\begin{array}{l}\text { Leadership } \\
\text { Positions }\end{array}$ & $\begin{array}{l}\text { Leadership } \\
\text { Positions }\end{array}$ & $\begin{array}{l}\text { Leadership } \\
\text { positions }\end{array}$ \\
\hline \multicolumn{5}{|l|}{ Jobs to Do } \\
\hline $\begin{array}{l}\text { Effective } \\
\text { Training }\end{array}$ & $\begin{array}{l}\text { Effective } \\
\text { Training }\end{array}$ & $\begin{array}{l}\text { Effective } \\
\text { Training }\end{array}$ & $\begin{array}{l}\text { Effective } \\
\text { Training }\end{array}$ & $\begin{array}{l}\text { Effective } \\
\text { Training }\end{array}$ \\
\hline Teamwork & Teamwork & Being a Team & Being a Team & Being a Team \\
\hline Role Modelling & Role Modelling & Role Modelling & Role Modelling & Role Modelling \\
\hline $\begin{array}{l}\text { Learning while } \\
\text { Doing }\end{array}$ & $\begin{array}{l}\text { Learning while } \\
\text { Doing }\end{array}$ & $\begin{array}{l}\text { Learning while } \\
\text { Doing }\end{array}$ & $\begin{array}{l}\text { Learning while } \\
\text { Doing }\end{array}$ & $\begin{array}{l}\text { Learning while } \\
\text { Doing }\end{array}$ \\
\hline \multicolumn{5}{|l|}{$\begin{array}{l}\text { Influences on } \\
\text { Leadership }\end{array}$} \\
\hline $\begin{array}{l}\text { Personal } \\
\text { Qualities }\end{array}$ & $\begin{array}{l}\text { Personal } \\
\text { Qualities }\end{array}$ & $\begin{array}{l}\text { Personal } \\
\text { Qualities }\end{array}$ & $\begin{array}{l}\text { Personal } \\
\text { Qualities }\end{array}$ & $\begin{array}{l}\text { Personal } \\
\text { Qualities }\end{array}$ \\
\hline Being a Leader & $\begin{array}{l}\text { Leadership } \\
\text { Identity } \\
\text { Formation }\end{array}$ & $\begin{array}{l}\text { Leadership } \\
\text { Identity } \\
\text { Formation }\end{array}$ & $\begin{array}{l}\text { Leadership } \\
\text { Identity } \\
\text { Formation }\end{array}$ & $\begin{array}{l}\text { Leadership } \\
\text { Identity } \\
\text { Formation }\end{array}$ \\
\hline \multirow[t]{3}{*}{$\begin{array}{l}\text { Leading from } \\
\text { Behind }\end{array}$} & $\begin{array}{l}\text { Leading from } \\
\text { Behind }\end{array}$ & $\begin{array}{l}\text { Leading from } \\
\text { Behind }\end{array}$ & $\begin{array}{l}\text { Leading from } \\
\text { Behind }\end{array}$ & $\begin{array}{l}\text { Leading from } \\
\text { Behind }\end{array}$ \\
\hline & & $\begin{array}{l}\text { Leading from } \\
\text { the Front }\end{array}$ & $\begin{array}{l}\text { Leading from } \\
\text { the Front }\end{array}$ & $\begin{array}{l}\text { Leading from } \\
\text { the Front }\end{array}$ \\
\hline & & & & $\begin{array}{l}\text { Leading from } \\
\text { Within }\end{array}$ \\
\hline $\begin{array}{l}\text { Leadership } \\
\text { styles }\end{array}$ & $\begin{array}{l}\text { Good } \\
\text { leadership } \\
\text { styles }\end{array}$ & & & \\
\hline $\begin{array}{l}\text { Caring about } \\
\text { Others }\end{array}$ & $\begin{array}{l}\text { Caring about } \\
\text { Others }\end{array}$ & $\begin{array}{l}\text { Caring about } \\
\text { Others }\end{array}$ & & \\
\hline $\begin{array}{l}\text { Learning to } \\
\text { Lead }\end{array}$ & $\begin{array}{l}\text { Learning to } \\
\text { Lead }\end{array}$ & $\begin{array}{l}\text { Learning to } \\
\text { Lead }\end{array}$ & & \\
\hline
\end{tabular}




\section{Final 12 Codes:}

Descriptive

- Leadership positions

- Relationships

- Personal qualities

- Skill development

\section{Pattern Making}

- Being a team

- Role modelling

- Leadership identity formation

- Learning while doing

- Leading from the front

- Leading from behind

- Effective training 


\section{Appendix F: Information and Consent Forms}

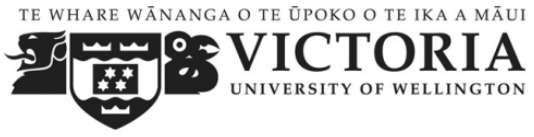

\section{FACULTY OF EDUCATION}

To the principal of schools involved in the research,

My name is Bronwyn Davies and I am completing a master's thesis at Victoria University of Wellington investigating the effectiveness of current student leadership training programmes. I am keen to interview students and teachers involved in leadership training in your school. My aim is to provide suggestions for schools on how to ensure that training prepares students for their leadership role and provides benefits for the school community. I am seeking permission for your school to be one of two case study schools participating in this research.

The university requires that ethics approval be obtained for research involving human participants. The thesis will contain no names or pseudonyms will be used. Your school and individual participants will not be identified. The information I collect will be used for my report and any related publications. This research has been assessed and approved by the Victoria University Faculty of Education Ethics Committee.

I would very much appreciate your assistance in this research on student leadership training in your school by allowing me to approach the teacher in charge of student leaders, 10 student leaders and 10 other students from the school body to participate. In order to approach the students from the school body I will also need your permission to access names from the school roll. My data gathering process includes interviews, observations and an on-line survey which will take place between May and August 2010. The interviews with students would take place at your school at a convenient time arranged in consultation with the teacher in charge of student leaders.

Your consent and school's participation are completely voluntary. If you agree to participate and subsequently change your mind, you are free to withdraw your consent without providing any explanation up until the interviews begin. You will be provided with a summary of the research findings. 
If you are prepared to participate, please let me know by filling in the consent form. Thank you very much for your time and help in making this study possible. If you have any queries or wish to know more, please contact me or my supervisor.

Yours sincerely,

Bronwyn Davies

\section{Researcher:}

Bronwyn Davies

School of Educational Policy and Implementation

Victoria University of Wellington College of Education

Phone: 4635233 ex 9401

e-mail: Bronwyn.davies@vuw.ac.nz

\section{Supervisor:}

Dr. Ann Bondy

Curriculum Leader, Senior Lecturer Technology

School of Educational Policy and Implementation

Victoria University of Wellington College of Education

Phone 4639529

e-mail: ann.bondy@vuw.ac.nz 
Information sheet for teachers:

My name is Bronwyn Davies and I am completing a master's thesis at Victoria University of Wellington investigating the effectiveness of current student leadership training programmes. My aim is to provide suggestions for schools on how to ensure that training prepares students for their leadership role and provides benefits for the school community.

The university requires that ethics approval be obtained for research involving human participants. I am keen to interview and observe students and teachers involved in leadership training in your school. Pseudonyms will be used in the thesis. Your school and individual participants will not be identified. The information I collect will be used for my report and any related publications. This research has been assessed and approved by the Victoria University Faculty of Education Ethics Committee.

I would very much appreciate your assistance in this research which would involve me conducting two interviews with you of up to an hour each in length and observing a leadership training session. Your assistance in recruiting student participants would also be appreciated. This would involve allowing me to meet with your student leaders in order to explain my research and ask for volunteer participants, from which 10 will be selected. I would like to interview each of these students for around half an hour each. I will work with you to set appropriate arrangements for when and where the interviews will take place. My data gathering with you and the students will take place between May and August 2010.

Your consent and participation are completely voluntary. If you agree to participate and subsequently change your mind, you are free to withdraw your consent without providing any explanation up until the interviews begin. You will be provided with the opportunity to read and comment on a draft of the report. If you are prepared to participate, please let me know by filling in the consent form. Thank you very much for your time and help in making this study possible. If you have any queries or wish to know more, please contact me or my supervisor.

Yours sincerely,

Bronwyn Davies 


\section{Researcher:}

Bronwyn Davies

School of Educational Policy and Implementation

Victoria University of Wellington College of Education

Phone: 4635233 ex 9401

e-mail: Bronwyn.davies@vuw.ac.nz

\section{Supervisor:}

Dr. Ann Bondy

Curriculum Leader, Senior Lecturer Technology

School of Educational Policy and Implementation

Victoria University of Wellington College of Education

Phone 4639529

e-mail: ann.bondy@vuw.ac.nz 


\section{Information sheet for students:}

My name is Bronwyn Davies and I am completing a master's thesis at Victoria University of Wellington investigating the effectiveness of current student leadership training programmes. I am keen to interview, observe and survey students involved in leadership training. My aim is to provide suggestions on how schools can best train their student leaders.

Responses to the interview questions will form the basis of my written report. The interview is likely to take half an hour. I am also keen to observe students and teachers during a leadership training session. I will take notes during the training. The final stage of my research is an online questionnaire which is likely to take fifteen minutes. Any information you provide and your answers to the questions will be kept confidential.

The university requires that ethics approval be obtained for research involving human participants. It will not be possible for you to be identified personally because pseudonyms will be used. You will be given the opportunity to read the interview transcript and observation notes. You will also be able to attend a feedback session after my data analysis is complete. This research has been assessed and approved by the Victoria University Faculty of Education Ethics Committee.

I would very much appreciate your assistance in this research. However, your consent and participation are completely voluntary. Should you feel the need to withdraw from the project you may do so, without providing any explanation, up until the data analysis begins. Just let me know.

If you are prepared to participate please let me know by filling in the consent form. Thank you very much for your time and help in making this study possible. If you have any queries or wish to know more, please contact me or my supervisor.

Yours sincerely,

Bronwyn Davies 


\section{Researcher:}

Bronwyn Davies

School of Educational Policy and Implementation

Victoria University of Wellington College of Education

Phone: 4635233 ex 9401

e-mail: Bronwyn.davies@vuw.ac.nz

\section{Supervisor:}

Dr. Ann Bondy

Curriculum Leader, Senior Lecturer Technology

School of Educational Policy and Implementation

Victoria University of Wellington College of Education

Phone 4639529

e-mail: ann.bondy@vuw.ac.nz 


\section{Consent form for school principals}

Please read the following and place a tick in each box if you agree with it:

I have had the research explained to me and had the opportunity to seek further explanation.

I consent to our school's student leadership training programme being part of this research, and the researcher having access to the teachers and student involved in this programme as well as a sample of students from the school body.

I understand that neither the school not any of the participants will be identifiable in the reported research.

$\square \quad$ I agree that the information collected can be used to meet the requirements for Bronwyn Davies' master's thesis.

I understand that the data collected may be used for conference papers and/or publication.

Your name:

Your signature:

Date: 


\section{Consent form for teachers}

Please read the following and place a tick in each box if you agree with it:

I agree to be a participant in this research.

I have had the research explained to me and had the opportunity to seek explanation and further clarification.

$\square$ I understand that agreeing to take part means that I am willing to be interviewed by the researcher.

$\square$ I understand that the interview responses will be digitally recorded.

$\square$ I understand that agreeing to take part means that I am willing to be observed by the researcher.

I understand that the researcher will make notes during the observation.

$\square$ I understand that I will have the opportunity to check a transcript of the interview and the observation notes up to three weeks after data gathering is complete...

I understand that the digital recording from the interview and the observation notes will be stored securely in a locked file.

I understand that the interview transcript and observation notes will be destroyed three years after the conclusion of the research.

I understand that any information collected or I provide is confidential and all participants will have pseudonyms.

I agree that the information collected can be used to meet the requirements for Bronwyn Davies' master's thesis.

$\square$ I agree that the data collected may be used for conference papers and/or publication.

$\square$ I understand that my participation is voluntary, that I can choose not to participate in the research, and that I can withdraw up to three weeks after the data gathering is complete without being penalised or disadvantaged in any way.

I want to receive a copy of the draft report to read and comment on.

Your name:

Your signature:

Date: 


\section{Consent form for students}

Please read the following and place a tick in each box if you agree with it:

I agree to be a participant in this research.

$\square$ I have had the research explained to me and the opportunity to seek further explanation and clarification.

$\square$ I agree to be interviewed.

$\square$ I agree to be observed during a training session.

$\square$ I agree to complete an on-line survey.

$\square$ I understand that the interview responses will be digitally recorded and later transcribed.

I understand that the researcher will make notes during the observation.

$\square$ I understand that I have the opportunity to check the observation notes and interview transcript up to three weeks after data gathering.

$\square$ I understand that the data will be stored securely in a locked file.

$\square$ I understand that the interview transcript, observation notes and answers to the survey will be destroyed three years after the conclusion of the research.

I understand that any information collected or I provide is confidential and all participants will have pseudonyms.

$\square$ I agree that the information collected can be used to meet the requirements for Bronwyn Davies' master's thesis.

I agree that the data collected may be used for conference papers and/or publication.

I understand that my participation is voluntary, that I can choose not to participate in the research, and that I can withdraw up to three weeks after the data gathering is complete (in which case any data I have provided will be destroyed) without being penalised or disadvantaged in any way.

I want to attend a feedback and question/answer session when the data analysis is complete.

Your name:

Your signature:

Date: 


\section{For students under 16 years of age}

I agree to my student participating in the research as explained in the student information sheet and consent form.

Parent/Guardian Name:

Parent/Guardian Signature:

Date: 